\title{
Development and characterization of novel and selective inhibitors of cytochrome P450 CYP26A1, the human liver retinoic acid hydroxylase
}

\author{
Philippe Diaz ${ }^{\S, \delta,{ }^{\star}, \text { Weize Huang }}{ }^{ \pm}$, Charles M. Keyari ${ }^{\S}$, Brian Buttrick $^{ \pm}$, Lauren Price $^{ \pm}$, \\ Nicolas Guilloteau ${ }^{\delta}$, Sasmita Tripathy ${ }^{ \pm}$, Vanessa G. Sperandio§, Frank R. Fronczek ${ }^{€}$, Fanny \\ Astruc-Diaz $^{\delta}$, and Nina Isoherranen ${ }^{\star}, \pm$ \\ ${ }^{ \pm}$Department of Pharmaceutics, University of Washington, Seattle, WA98195 \\ $\S$ Department of Biomedical and Pharmaceutical Sciences, The University of Montana, 32 \\ Campus Drive, Missoula, MT 59812, USA \\ ${ }^{€}$ Chemistry Department, Louisiana State University, 612 Choppin Hall, Baton Rouge, LA 70803, \\ USA \\ ${ }^{\delta}$ DermaXon LLC, 32 Campus Drive, Missoula, MT 59812, USA
}

\section{Abstract}

Cytochrome P450 CYP26 enzymes are responsible for all-trans-retinoic acid (atRA) clearance. Inhibition of CYP26 enzymes will increase endogenous atRA concentrations and is an attractive therapeutic target. However, the selectivity and potency of the existing a $t$ RA metabolism inhibitors towards CYP26A1 and CYP26B1 is unknown, and no selective CYP26A1 or CYP26B1 inhibitors have been developed. Here the synthesis and potent inhibitory activity of the first CYP26A1 selective inhibitors is reported. A series of non-azole CYP26A1 selective inhibitors was identified with low nM potency. The lead compound 3-\{4-[2-(5,5,8,8-tetramethyl-5,6,7,8-

tetrahydronaphthalen-2-yl)-1,3-dioxolan-2-yl] phenyl 4 propanoic acid (24) had 43-fold selectivity towards CYP26A1 with an $\mathrm{IC}_{50}$ of $340 \mathrm{nM}$. Compound 24 and its two structural analogs also inhibited a $t$ RA metabolism in HepG 2 cells resulting in increased potency of a $t R A$ towards RAR activation. The identified compounds have potential to become novel treatments aiming to elevate endogenous a $t R A$ concentrations and may be useful as cotreatment with a $\mathbb{R A}$ to combat therapy resistance.

\section{Graphical Abstract}

*Corresponding Authors: For chemistry: P. Diaz: phone: 406-243-4362; fax: 406-243-5228; Philippe.diaz@umontana.edu. For biology: N. Isoherranen, phone: 206-543-2517, Fax: 206-543-3204, ni2@u.washington.edu.

Supporting Information. Additional characterization data, ${ }^{1} \mathrm{H}$ and ${ }^{13} \mathrm{C}-\mathrm{NMR}$ spectra, compound purity. 


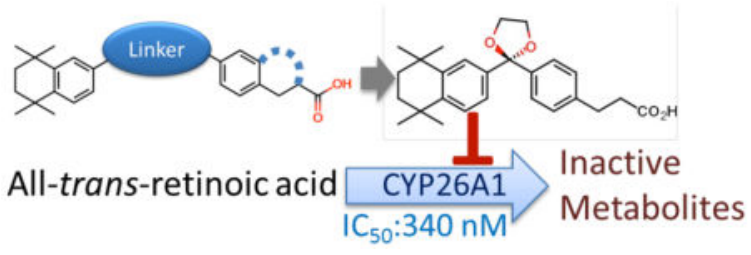

\section{Keywords}

Cytochrome P450; retinoic acid; CYP26; retinoic acid receptor

\section{INTRODUCTION}

Retinoic acid (RA) is the endogenous active metabolite of vitamin A (retinol). It is an essential regulator of cell growth, cell cycle and differentiation. ${ }^{1,2}$ RA exists in several isomeric forms, all-trans retinoic acid (a $t \mathrm{RA}), 13$-cis-retinoic acid (13-cisRA), 9,13-dicisretinoic acid (9,13-dicisRA), and 9-cis-retinoic acid (9-cisRA). ${ }^{3}$ Of these isomers, atRA is believed to be the main biologically active form exhibiting its activity through binding predominantly to nuclear retinoic acid receptors (RARs). Through its binding to nuclear receptors and regulating gene transcription, atRA plays a critical role in many biological processes including reproduction, maintenance of skin and epithelia, regulation of the immune system and T- and B-cell function, and in fetal development. ${ }^{4-6}$ In addition, imbalance in vitamin A and RA homeostasis has been implied in development and progression of several human diseases such as acne, psoriasis and ichthyosis, type II diabetes, neurodegenerative diseases and some cancers. ${ }^{1}$ The potential of RA in the treatment of human diseases has been manifested in the success of 13-cisRA (Accutane) in treatment of acne and neuroblastoma, and the effectiveness of a $\mathbb{R A}$ in the treatment of acute promyelocytic leukemia (APL). However, the use and long term efficacy of a $t$ RA has been limited in all of the therapeutic areas by its high clearance that limits oral administration of this agent, and the resistance that develops towards a $t$ RA due to autoinduction of its metabolism. ${ }^{7}$ Additionally 13 cis-RA via isomerization to atRA, and atRA both cause broad activation of RARs that is believed to be responsible for some of the untoward side effects of these agents. Due to these shortcomings, the full clinical and therapeutic potential of retinoids has not been reached.

The clearance of a $\mathrm{RA}$ is predominantly mediated by cytochrome $\mathrm{P} 450$ family 26 enzymes (CYP26). ${ }^{8,9}$ The CYP26 family has three isoforms: CYP26A1, CYP26B1 and CYP26C1 which are expressed in a tissue specific manner. In the human liver CYP26A1 is the predominant CYP26 enzyme responsible for majority of the hepatic clearance of atRA. ${ }^{10}$ CYP26B1 protein is not detected in human liver and the expression of this isoform appears to be restricted to extrahepatic sites. ${ }^{11}$ The biological role and expression pattern of CYP26C1 is not well characterized but this enzyme appears to be responsible for 9-cisRA metabolism and be less critical in regulating RA concentrations than CYP26A1 and CYP26B1. 
As a $t$ RA is predominantly cleared by the CYP26 enzymes, it has been proposed that inhibition of the CYP26 enzymes will increase atRA concentrations in target tissues, and inhibition of CYP26 enzymes during a $t$ RA or 13-cisRA therapy could be used to combat disease resistance. ${ }^{12}$ However, inhibitors of CYP26 that have been tested in humans (Figure 1) commonly suffer from broad spectrum CYP inhibition resulting in untoward side effects. Examples of this include the inhibition of steroid metabolism by liarozole (compound $\mathbf{1}$ ) and the drug-drug interactions seen with ketoconazole (compound 2). ${ }^{7}$ The lack of specificity of these inhibitors is likely due to the imidazole and triazole moieties in the compounds that are known to coordinate with the heme iron providing additional potency towards CYP inhibition. Although more selective triazole and imidazole containing CYP26 inhibitors have been developed, ${ }^{7}$ none of these compounds has yet reached human trials and therefore their drug-drug interaction potential in vivo is unknown. In addition, none of the existing inhibitors of CYP26s have been evaluated for specificity between the CYP26 enzymes and therefore the benefits and shortcomings of selective or broad CYP26 inhibition have not been established.

CYP26 enzymes appear to have cell type and tissue specific expression, ${ }^{11}$ and therefore it is likely that specific CYP26A1 or CYP26B1 inhibitors would be beneficial for increasing RA concentrations in selected target tissues without causing broad side effects. Specifically, since CYP26A1 appears to be the predominant CYP26 enzyme in the liver, selective inhibition of CYP26A1 is expected to decrease systemic clearance of atRA and therefore be useful for combatting therapy resistance in individuals being treated with atRA or 13 cisRA. In addition, it is likely that use of CYP26A1 specific inhibitor will selectively increase RA concentrations in the liver. Notably, based on conditional knock-out mouse studies, CYP26B1 inhibition could be a liability for male reproduction as testes cell type specific CYP26B1 knock-out mice show adverse effects on the testes. ${ }^{14}$ Similarly, T-cell specific CYP26B1 knockouts have shown that CYP26B1 regulates iTreg and Th17 cell polarization, ${ }^{15}$ an effect that may be a liability for a broad CYP26 inhibitor. A CYP26A1 selective inhibitor would avoid both of these effects and likely be beneficial when systemic atRA concentrations are targeted.

The aim of this study was to identify novel non-azole inhibitors of CYP26 enzymes that would be selective for CYP26A1 and devoid of CYP26B1 inhibition. A series of novel CYP26A1 selective inhibitors was identified with low nM potency for CYP26A1 inhibition. The lead compound from the series had 43-fold selectivity towards CYP26A1 in comparison to CYP26B1 and other P450 enzymes and inhibited CYP26A1 with an $\mathrm{IC}_{50}$ of $340 \mathrm{nM}$. The lead compound and two of its structural analogs also inhibited atRA metabolism in HepG2 cells resulting in increased potency of a $t$ RA towards RAR activation in these cells. The identified compounds are the first CYP26A1 selective inhibitors discovered and have potential to become novel treatments aiming to elevate endogenous RA concentrations in circulation and in the liver. These compounds would also be useful as cotreatment with atRA to combat therapy resistance likely caused by increased systemic clearance of a $t R A$ and autoinduciton of CYP26A1, particularly in the liver. 


\section{RESULTS}

\section{Chemistry}

Initial coupling of 2-bromo-1-(5,5,8,8-tetramethyl-5,6,7,8-tetrahydronaphthalen-2-

yl)ethan-1-one with methyl-4-hydroxybenzoate in the presence of $\mathrm{K}_{2} \mathrm{CO}_{3}$ in methyl ethyl ketone under microwave conditions, gave ester $\mathbf{4}$ in good yield (Scheme 1). It was further hydrolyzed under basic conditions to afford carboxylic acid $\mathbf{5}$ in good yield. Reduction of the ketone moiety of compound 4 to alcohol by treatment with $\mathrm{NaBH}_{4}$, followed by basic hydrolysis at the ester position, gave carboxylic acid $\mathbf{6}$. Reaction of $\mathbf{4}$ with hydroxylamine hydrochloride in $\mathrm{MeOH}$ under reflux formed oxime isomers $\mathrm{E}(\mathbf{7})$ and $\mathrm{Z}(\mathbf{8})$, in moderate and good yield, respectively. Z-isomer 8 was further hydrolyzed in aqueous $\mathrm{K}_{2} \mathrm{CO}_{3}$ to provide carboxylic acid 9.

Friedel-Crafts acylation ${ }^{16,17}$ of 1,1,4,4-tetramethyl-1,2,3,4-tetrahydronaphthalene (TTN) with methyl 4-(chlorocarbonyl)benzoate and methyl 6-(chlorocarbonyl)naphthalene-2carboxylate in $\mathrm{CH}_{2} \mathrm{Cl}_{2}$ in the presence of $\mathrm{AlCl}_{3}$ yielded the expected ketones $10 \mathbf{a}$ and $\mathbf{1 0 b}$ (Scheme 2). The ester moieties of 10a and $\mathbf{1 0 b}$ were then hydrolyzed in basic conditions to respectively afford carboxylic acids $11 \mathbf{a}$ and 11b in excellent yields. Further, treatment of the ketone 10a and 10b with ethylene glycol ${ }^{17}$ resulted in the formation of ketals 12a and 12b which after basic hydrolysis, afforded the expected carboxylic acids 13a and 13b. Likewise thioketalization of $10 \mathrm{a}$ and $\mathbf{1 0 b}$ was achieved by reaction with ethanedithiol in the presence of boron trifluoride diethyl etherate $\left(\mathrm{BF}_{3} \cdot \mathrm{Et}_{2} \mathrm{O}\right)$, giving the thioketals $14 \mathbf{a}$ and $14 \mathbf{b}$ in excellent yields which after basic hydrolysis, gave carboxylic acids 15a and $\mathbf{1 5 b}$.

Friedel-Crafts acylation ${ }^{16}$ of TTN by 4-iodobenzoyl chloride according to the previously described procedure, afforded ketone $\mathbf{1 6}$ in good yield (Scheme 3). Heck ${ }^{18,19}$ coupling reaction of $\mathbf{1 6}$ with methyl acrylate under palladium catalysis proceeded smoothly to give alkene 17. Compound $\mathbf{1 7}$ was then hydrolyzed under basic conditions, to give carboxylic acid 18. Hydrogenation of $\mathbf{1 7}$ under $\mathrm{Pd} / \mathrm{C}$ catalysis not only reduced the alkene moiety, but also the carbonyl moiety resulting in the formation of benzylbenzene $\mathbf{1 9}$ which upon subsequent basic hydrolysis provided the corresponding carboxylic acid 20. Ketalization of 17 was carried out according to the previously described procedure, to afford ketal 21 in moderate yield which after basic hydrolysis gave carboxylic acid 22. Hydrogenation of $\mathbf{2 1}$ in presence of $\mathrm{Pd} / \mathrm{C}$ followed by hydrolysis gave carboxylic acid $\mathbf{2 4}$. The ketal moiety of $\mathbf{2 3}$ was cleaved with iodine in acetone under reflux according to a modified procedure of Sun et al, ${ }^{20}$ to afford ketone $\mathbf{2 5}$ which after saponification yielded to the carboxylic acid $\mathbf{2 6}$. Thioketalization of $\mathbf{1 7}$ followed by hydrolysis provided carboxylic acid $\mathbf{2 8}$. The alkene moiety of $\mathbf{2 8}$ was found to be resistant to hydrogenation using Pd-C or Wilkinson's catalyst. Therefore, ketal 29 was obtained directly from the thioketalization of ketone $\mathbf{2 5}$ which after basic hydrolysis gave carboxylic acid $\mathbf{3 0}$.

Sulfone 34 was prepared in 4 steps starting from TTN. TTN was first converted to disulfide 31 (Scheme 4) by treatment with chlorosulfonic acid followed by heating in presence of zinc in hydrochloric acid. ${ }^{21}$ Disulfide 31 was then reduced and coupled with ethyl 3-(4bromophenyl)propanoate in presence of $\mathrm{PdCl}_{2}(\mathrm{dppf})$ and zinc, ${ }^{22}$ to give diaryl sulfide 32 . 
Oxidation of $\mathbf{3 2}$ with oxone produced the expected sulfone $\mathbf{3 3}$ which after hydrolysis under basic condition afforded carboxylic acid $\mathbf{3 4}$ in good yield.

To explore the role of the atoms of oxygen (or sulfur) from the dioxolane (dithiolane) moiety, we investigated the activity of a novel series of compounds with a sulfide moiety or a sulfoxide moiety as a linker in between the two aromatic rings. Synthesis started with preparation of iodo TTN derivative $\mathbf{3 5}$ from TTN (Scheme 5). ${ }^{23}$ Diaryl sulfides 36a and 36b were then prepared by nickel catalyzed coupling with the iodo derivative $\mathbf{3 2}$ in the presence of polymer-supported borohydride in butanol, to respectively provide the 4- and 3mercaptophenylacetic acid methyl esters. ${ }^{24}$ Methyl esters 36a and 36b were obtained as mixtures with their butyl ester analogues (25\% butyl ester). Biaryl sulfides 36a and 36b were then oxidized with oxone in methanol to afford the expected biaryl sulfones 37a and 37b. Compounds 36a, 36b, 37a and 37b were then hydrolyzed under basic conditions to afford the desired carboxylic acids 38a, 38b, 39a and 39b respectively in good to excellent yields.

\section{Enzyme Inhibition and structure-activity relationship}

A method was previously developed using recombinant CYP26A1 microsomes and 9-cisRA as a substrate to test for inhibition of CYP26A1. ${ }^{25}$ Previously, 9-cis-RA was chosen as the screening substrate instead of atRA due to the lack of substrate and metabolite depletion in the screening assays with 9-cis-RA, and the lower affinity of 9-cis-RA to CYP26A1 when compared to atRA allowing screening of inhibitors at substrate concentration at or below the $\mathrm{K}_{\mathrm{m}}$ value. ${ }^{25}$ Similar to CYP26A1, atRA is a high affinity substrate of CYP26B1 and the metabolites formed by CYP26B1 are also substrates of CYP26B $1{ }^{11}$ confounding kinetic inhibition measurements. To allow characterization of inhibition of CYP26B1, 9-cis-RA turnover by recombinant CYP26B1 was also characterized. 9-cis-RA was found to be a substrate of CYP26B1 and the formation of the metabolite that coeluted with 9-cis-4-OHRA was NADPH dependent. The $\mathrm{K}_{\mathrm{m}}$ and $\mathrm{V}_{\max }$ for 9-cis-4-OH-RA formation by CYP26B1 were of $555 \mathrm{nM}$ and $3.6 \mathrm{pmol} / \mathrm{min} / \mathrm{pmol} \mathrm{P} 450$, respectively. Based on the $\mathrm{K}_{\mathrm{m}}$ value, all compounds were evaluated for CYP26B1 inhibition at a substrate (9-cis-RA) concentration of $100 \mathrm{nM}$ (concentration $\ll \mathrm{K}_{\mathrm{m}}$ to increase sensitivity and decrease the dependence of $\mathrm{IC}_{50}$ values on inhibition mechanism).

In an effort to identify lead CYP26A1 specific inhibitors, we decided to focus our screening on synthetic analogues of RA. The compounds were selected on the basis of structural similarity with a $t R A$, the endogenous substrate of CYP26A1, and a small number of analogues were prepared to obtain an initial characterization of the structure-activity relationships (SAR) of CYP26A1 binding and selectivity. This approach was based on prior work showing that some RAR agonists bind and inhibit CYP26A1. ${ }^{25}$ The classic RAMBAs (compounds $\mathbf{1}$ and $\mathbf{3}$ ) and three commercially available synthetic retinoids $\mathbf{4 0}$ (bexarotene) (Table 1), 13a (SR1123726) (Table 2), and 15b (MM1125327) (Table 1), and two close analogues 13b and 15a, were tested for their CYP26A1 and CYP26B1 inhibition potency. This screening showed that both the RAMBAs and synthetic retinoids inhibited CYP26A1 and CYP26B1 (Table 1 and 2). The azole containing compound 3 inhibited both CYP26A1 and CYP26B1 potently whereas compound 1 was a more potent inhibitor of CYP26B1 than 
CYP26A1. Neither one of these compounds provided sufficient specificity and selectivity to inhibit atRA metabolism specifically by CYP26A1.

Compounds 40, 13a and 15a had $\mathrm{IC}_{50}$ values in the micromolar range and did not demonstrate significant selectivity for CYP26A1, whereas the RAR $\gamma$ selective antagonist $\mathbf{1 5 b}^{28}$ had a $0.061 \mu \mathrm{M} \mathrm{IC}$ F0 $_{50}$ fYP26A1 and $1.03 \mu \mathrm{M} \mathrm{IC}$ 50 for CYP26B1 (Table 1) demonstrating a 17 -fold higher $\mathrm{IC}_{50}$ towards CYP26B1 than CYP26A1. Compound $\mathbf{1 3 b}$, the ketal homologue of 15b displayed the same CYP26B1 inhibitory activity but exhibited a reduced CYP26A1 activity compared to the thioketal analogues. Replacement of the original dithiolane linker of $\mathbf{1 5 b}$ by a carbonyl in compounds $\mathbf{1 1 b}$ and $\mathbf{1 8}$, and synthesis of their shorter homologues 11a and 15a resulted in a reduction of CYP26A1 inhibitory activities and a modest enhancement of CYP26B1 inhibition for compound 11b. All these data together indicate that the geometry of the thioketal ring and the distance between the carboxylic acid and the thioketal moiety are crucial for the CYP26A1 inhibitory activity. Our subsequent research efforts to complete SAR of synthetic retinoids led to the synthesis of compounds 5, $\mathbf{6}$ and $\mathbf{9}$. We decided to incorporate polar groups in the spacer between the two aromatic moieties to explore potential hydrogen bonding interaction with CYP26A1. The distance between the carboxylic acid and the tetramethyltetrahydronaphthalene moiety was kept in the same range as for compound $\mathbf{1 5 b}$. The naphthyl moiety was replaced by a methyleneoxyphenyl moiety to minimize potential steric hindrance that would prevent hydrogen bonding. However, such a chemical modification did not produce significant improvement in affinity towards CYP26A1. We also explored the effect of potential steric hindrance on compound $\mathbf{1 1 b}$ by replacing the naphthyl moiety by a styryl moiety (18) This change led to a dramatic loss of CYP26B1 inhibition and a 2 to 3 -fold reduction in CYP26A1 activity. A similar trend was observed for the CYP26B1 activity of the styryl derivative $\mathbf{2 2}$ whereas CYP26A1 activity was comparable to the naphthyl analogue $\mathbf{1 3 b}$. Surprisingly compound $\mathbf{2 8}$, the styryl analogue of compound $\mathbf{1 5 b}$ was not active towards CYP26A1. While 15b is a potent inhibitor of CYP26A1 it is not an ideal inhibitor to be developed further due to its high RAR affinity. ${ }^{28}$ Therefore, $\mathbf{1 5 b}$ was chosen as a lead compound for the design and synthesis of novel inhibitors that would be free of RAR binding (agonist or antagonist), and inhibition of other P450s except CYP26A1. We decided to explore the effect of the replacement of the naphthyl group bearing the carboxylic acid by a phenethyl group on CYP26 and RAR activities. Phenethyl derivative $\mathbf{2 4}$ displayed a lower CYP26B1 activity compared to the naphthyl analogue 13b while CYP26A1 activity was only reduced by 2 to 3 -fold. CYP26A1 inhibitory activity for the thioketal analogue $\mathbf{3 0}$ was in the same range of compound $\mathbf{2 4}$ whereas CYP26B1 activity was increased. We also explored whether it is possible to improve CYP26A1 inhibitory activity and selectivity by modifying the substituents on the one-carbon between the two ring systems of compound 24. These will result in the modification of the spatial orientation of the two aromatic moieties. Such a chemical modification did not produce significant improvement in CYP26 inhibition for analogues 20, 26 and 34. In the course of our initial exploratory work on the SARs for this novel series of CYP26 inhibitors, we also explored whether it is possible to impact the spatial positioning of the carboxylic moiety by shortening the phenethyl moiety. The thioethers $(\mathbf{3 8 a}, \mathbf{3 8 b})$ and the sulfones $(\mathbf{3 9} \mathbf{a}, \mathbf{3 9 b})$ lacked inhibitory activity towards CYP26A1 and CYP26B1. 
In summary, in contrast to the relatively robust nanomolar inhibition of CYP26A1 by the dithiolane and dioxolane compounds in this series, and the micromolar inhibition of CYP26A1 by majority of the remaining compounds, the inhibitory potency of the compounds (5-39) towards CYP26B1 was variable with only compounds $\mathbf{1 1 b}, \mathbf{3 0}$ and 5 showing submicromolar potency towards CYP26B1. Interestingly, compounds $\mathbf{5 , 6 , 9 , 1 1 b}$, 34 were more potent inhibitors of CYP26B1 than CYP26A1 suggesting that interactions between these inhibitors and the CYP26 enzymes within the active site are different allowing development of CYP26 isoform selective inhibitors. Compounds 15b and 13b were approximately 10-20 fold more potent inhibitors of CYP26A1 than CYP26B1. The replacement of the naphthyl group in the dioxolane compound $\mathbf{1 3 b}$ with a saturated or an unsaturated two carbon chain (22 and 24) led to over 10-fold decrease in the CYP26B1 inhibition with a lower effect on CYP26A1 inhibition. Therefore, these changes increased the CYP26A1 selectivity to >40-fold between CYP26B1 and CYP26A1. In contrast, with the dithiolane compound $\mathbf{1 5 b}$, replacement of the naphthyl with an unsaturated or a saturated two carbon chain led to either considerable decrease in CYP26A1 inhibition (28) or loss of CYP26A1 selectivity (30).

\section{RAR activation}

The initial lead compound in the series, $\mathbf{1 5 b}$, is a known RAR antagonist ${ }^{28}$ and therefore it is possible that also the novel compounds identified will possess off-target effects via RAR binding. Hence, the two most promising selective inhibitors, compounds $\mathbf{2 2}$ and $\mathbf{2 4}$, as well as compound $\mathbf{3 0}$ which was a potent non-selective CYP26A1/B1 inhibitor, were assessed for RAR activation. We first used a luciferase-based reporter assay to screen compounds $\mathbf{2 2}, \mathbf{2 4}$ and 30 for RARa and RAR $\gamma$ activation at a concentration of $1 \mu \mathrm{M}$. Screen was accomplished using human RARa and RAR $\gamma$ reporter assay kits provided by Indigo Biosciences as reported previously. No measurable RARa and RAR $\gamma$ activation was detected for the three compounds (Data not shown). We then used the HepG2 cells, which have robust atRA metabolism activity and RAR mediated effects on gene transcription ${ }^{29}$ to test the effects of compounds $\mathbf{2 2 ,} \mathbf{2 4}$ and $\mathbf{3 0}$ on RAR activation in a cell system. The induction of the mRNA of the classic RAR target genes CYP26A1 and RAR $\beta$ was evaluated after treatment with each of the novel compounds in comparison to vehicle and atRA (Figure 2). As shown, none of the three compounds resulted in activation of the pool of RARs in the HepG 2 cells at a test concentration of $1 \mu \mathrm{M}$, a concentration at least 5 times greater than the $\mathrm{IC}_{50}$ value of these compounds towards CYP26A1.

\section{Inhibition of RA metabolism and Enhancement of RA potency}

To further determine the biological activity of the lead compounds, their efficacy to increase the potency of a $\mathbb{R A}$ was tested in the HepG 2 cells. It has been previously shown that a $\mathbb{R A}$ is efficiently metabolized in HepG2 cells and that the metabolism of atRA in HepG2 cells is predominantly mediated by CYP26A1 ${ }^{29}$ Therefore, RA metabolism in HepG2 cells and the activation of RARs (CYP26A1 and RAR $\beta$ induction) by a $t$ RA in these cells provide a reliable test system for cellular activity of the compounds of interest. When HepG2 cells were treated with $100 \mathrm{nM}$ atRA in combination with $1 \mu \mathrm{M}$ of compounds $\mathbf{2 2}, \mathbf{2 4}$ and $\mathbf{3 0}$, the magnitude of induction of RAR $\beta$ and CYP26A1 was significantly increased when compared 
to atRA treatment alone (Figure 2), demonstrating that all three compounds potentiate the effect of a $t$ RA in cells presumably via inhibiting a $t$ RA metabolism and increasing the cellular concentrations of a $t$ RA. Importantly the induction of RAR $\beta$ and CYP26A1 following treatment with $100 \mathrm{nM}$ atRA together with the inhibitors was significantly greater than the induction observed following treatment with $1 \mu \mathrm{M}$ a $t \mathrm{RA}$ alone demonstrating a considerable increase in the potency of a $t$ RA by the inhibitors. Furthermore these data demonstrate that these compounds do not exhibit an RAR antagonistic activity.

To test whether the increased induction of RAR target genes in the presence of the inhibitors and atRA was due to inhibition of atRA depletion in the cells, the concentrations of a $t \mathrm{RA}$ in the media at the end of the 24-hour treatment were measured. Table 3 summarizes the effects of the lead compounds on atRA depletion in HepG2 cells. All three CYP26 inhibitors significantly increased a $t$ RA concentrations in the cell media with compound $\mathbf{3 0}$ having the greatest effect, approximately 9-fold increase in atRA concentrations in the media. Compound 22 increased a $t R A$ concentration 3.5-fold and compound 24 increased a $t \mathrm{RA}$ concentration in the media by 2 -fold. This increase in atRA concentrations correlated well with the observed magnitude of effect on potentiating atRA mediated RAR activation in cells with compound $\mathbf{3 0}$ also having the greatest effect on increasing a $t \mathrm{RA}$ mediated induction of RAR $\beta$ and CYP26A1.

\section{Selectivity for CYP26A1}

To determine the selectivity of the lead compounds towards other P450 enzymes the inhibition of CYP2D6, CYP3A4, CYP2C19 and CYP2B6 by compounds 22, 24 and 30 was evaluated. The inhibition data is summarized in Table 4 . When screened at $10 \mu \mathrm{M}$ inhibitor concentration, compounds $\mathbf{2 2}$ and $\mathbf{2 4}$ were free of any CYP3A4 inhibition while compound 30 inhibited CYP3A4 by 25\%. The $\mathrm{IC}_{50}$ values for CYP3A4 inhibition for compounds 22 and 30 were $30 \mu \mathrm{M}$ and $7.5 \mu \mathrm{M}$ respectively. For compound 24 no concentration dependent inhibition of CYP3A4 was observed up to $100 \mu \mathrm{M}$ with maximum $40 \%$ inhibition observed, demonstrating that compound $\mathbf{2 4}$ is unlikely to result in CYP3A4 inhibition at concentrations required to inhibit CYP26A1. Similarly, compound $\mathbf{2 4}$ was free of any significant inhibition of CYP2D6, CYP2C19 and CYP2B6 suggesting that this compound may become a novel CYP26A1 selective inhibitor. In contrast compound 22 inhibited CYP2D6 by $50 \%$ at $10 \mu \mathrm{M}$ concentration and compound $\mathbf{3 0}$ inhibited CYP2B 6 by $70 \%$ at 10 $\mu \mathrm{M}$.

\section{DISCUSSION}

Inhibition of atRA metabolism has been a potential drug target for some decades now and several promising inhibitors of overall atRA metabolism have emerged from variety of drug development programs in industry and academia. ${ }^{7}$ Yet, in the development of the inhibitors of atRA metabolism or CYP26, the role of inhibition of the different CYP26 isoforms has never been addressed. In fact, the screening data in this study shows that talarozole is a potent inhibitor of both CYP26A1 and CYP26B1 while liarozole is a preferential inhibitor of CYP26B1. This difference in their inhibition profile likely contributes to some differences in their in vivo pharmacology and side effect profile. As CYP26A1 and CYP26B1 are 
expressed in a tissue specific manner, ${ }^{11}$ selective inhibition of either CYP26 isoform holds great promise in organ specific targeting of the retinoid system. This study is the first to test and identify CYP26 isoform specific inhibitors with the goal of identifying a CYP26A1 selective inhibitor that can be used to inhibit atRA metabolism in the liver. Compound $\mathbf{2 4}$ has 43-fold specificity towards CYP26A1 compared to CYP26B1 and it emerged as the lead inhibitor in this novel structural series. The selectivity of compound $\mathbf{2 4}$ together with compounds $\mathbf{1 5 b}, \mathbf{1 3 b}$ and $\mathbf{2 2}$ is striking as up to now only minor differences in the biochemical structure function between CYP26A1 and CYP26B1 have been observed. Both enzymes use a $t R A$ as a substrate, bind a $\mathbb{R A}$ with high affinity and form very similar metabolites from a $t \mathrm{RA}$ although at slightly different product ratios. ${ }^{11}$ This is despite the fact that the two CYP26 enzymes only share about $40 \%$ sequence similarity and hence would be expected to be structurally and functionally different. As the CYP26 enzymes have proven exceedingly difficult to express and purify in recombinant systems, no X-ray crystal structure or low-resolution structural information is available for these enzymes at present. Therefore the discovery of these novel selective inhibitors of CYP26A1 provide critical insight to the differences in the active site features and structure-activity relationships of these two enzymes and provide a lead for future development of selective inhibitors of the two enzymes.

The novel compounds in this series were developed using known RAR ligands as lead compounds and by exploring synthetically feasible modifications that could reduce RAR binding activity without compromising CYP26A1 inhibition. Replacement of the naphthyl group of the dioxolane derivative 13b by a phenethyl moiety in compound 24 appears to have a minor impact on CYP26A1 inhibitory activity while reducing CYP26B1 activity. The results in HepG2 cells show that indeed the lead compounds 22, 24 and $\mathbf{3 0}$ were devoid of RAR modulation while maintaining the CYP26 inhibition potency. In addition, the studies in HepG 2 cells showed that compound $\mathbf{2 4}$ and the two other potent inhibitors in this series, compounds 22 and 30, were effective at inhibiting atRA metabolism in cell culture systems and they potentiated the activity of atRA in the cell system. To mimic the in vivo endogenous a $t$ RA concentrations in cells, the HepG2 cells were treated with $100 \mathrm{nM}$ a $t R A$ and under these conditions, the lead inhibitors increased the activity of atRA by $5-100$ fold and decreased atRA metabolism significantly. The HepG2 cells have been previously shown to be devoid of CYP26B1 expression although CYP26B1 expression is somewhat inducible in these cells. ${ }^{30}$ Similarly HepG2 cells do not express significant levels of the common drug metabolizing enzymes such as CYP3A4 and CYP2C enzymes. Therefore it is likely that the effect of the inhibitors on atRA activity in these cells is solely due to CYP26A1 inhibition.

In this investigation, we present a broad range of experimental data on a novel series of retinoid-based CYP26A1 inhibitors. Within this series, a SAR could be established that showed that lipophilic bulk induced by a dioxolane or a dithiolane on the spacer appears to be required for enhanced CYP26A1 inhibitory activity. Dioxolane analogues $\mathbf{2 2}$ and $\mathbf{2 4}$ were identified as selective CYP26A1 inhibitors. Classic CYP26 inhibitors have all included a triazole or imidazole functional group to increase their affinity to CYP26s via coordination to the heme iron. ${ }^{31,32}$ However, atRA itself binds to CYP26A1 with $10 \mathrm{nM}$ affinity suggesting that high affinity inhibitors devoid of the imidazole or triazole group prone to 
broad spectrum CYP inhibition can be developed. Indeed, this study shows that $\mathrm{nM}$ inhibitors of both CYP26A1 and CYP26B1 free of imidazole or triazole functionality can be synthesized. These inhibitors were also free of inhibition of off-target CYPs such as CYP3A4, CYP2C19 and CYP2D6 at concentrations relevant for CYP26A1 inhibition. However, these compounds do include a ketal that may be metabolically labile and compound $\mathbf{2 2}$ is an unsaturated acid. These functional groups are potential in vivo liabilities of these compounds and require further study. Nevertheless, these compounds provide the first structural leads for selective CYP26A1 inhibition, and have the potential to become the first selective CYP26A1 inhibitors for testing in preclinical models. Eventually these compounds may become useful for treatment of diseases that would require increasing systemic or liver a $t$ RA concentrations or in inhibiting a $t R A$ metabolism when a $t R A$ is administered clinically to combat therapy resistance that develops due to CYP26A1 induction by a $t$ RA.

\section{EXPERIMENTAL SECTION}

\section{General Experimental methods}

Moisture sensitive reactions were performed in an inert, dry atmosphere of argon in flame dried glassware. Air sensitive liquids were transferred via syringe or cannula through rubber septa. Reagent grade solvents were used for extraction and flash chromatography. THF was distilled from $\mathrm{Na}$ /benzophenone under argon; dichloromethane $\left(\mathrm{CH}_{2} \mathrm{Cl}_{2}\right)$ and chloroform $\left(\mathrm{CHCl}_{3}\right)$ were distilled from $\mathrm{CaH}_{2}$ under argon. All other reagents including 2-bromo-1(5,5,8,8-tetramethyl-5,6,7,8-tetrahydronaphthalen-2-yl)ethan-1-one and 1,1,4,4tetramethyl-1,2,3,4-tetrahydronaphthalene and solvents which were purchased from commercial sources, were used directly without further purification. The progress of reactions was checked by analytical thin-layer chromatography (Sorbent Technologies, Silica G TLC plates w/UV 254). Flash column chromatography was performed using prepacked Biotage SNAP/ZIP cartridges on a Biotage Isolera One instrument. Microwave reactions were performed using a Biotage Initiator instrument. The solvent compositions reported for all chromatographic separations are on a volume/volume (v/v) basis. ${ }^{1} \mathrm{HNMR}$ spectra were recorded at 400 or $500 \mathrm{MHz}$ and are reported in parts per million (ppm) on the $\delta$ scale relative to tetramethylsilane as an internal standard. ${ }^{13} \mathrm{CNMR}$ spectra were recorded at 100 or $125 \mathrm{MHz}$ and are reported in parts per million (ppm) on the $\delta$ scale relative to $\mathrm{CDCl}_{3}$. Melting points were determined on a Stuart melting point apparatus from Bibby Scientific Limited and are uncorrected. LC-UV and high resolution mass spectrometry (HRMS) analyses were conducted on a Waters ACQUITY UPLC-series liquid chromatography system equipped with a diode array detector and LCT PREMIER XE ${ }^{\mathrm{TM}}$ time of flight (TOF) mass spectrometer operated on the electrospray ionization mode. Compounds were separated using a Phenomenex (Torrance, CA) NX-C18 column $(50 \times$ $4.60 \mathrm{~mm}$ ) with $3 \mu \mathrm{m}$ particle size and gradient elution at mobile phase flow rate of 0.4 $\mathrm{mL} / \mathrm{min}$ with solvents A: water with $0.1 \%$ formic acid and B: acetonitrile. The gradient was from $90 \%$ A $10 \%$ B to $2 \%$ A $98 \%$ B over 6.6 min then held isocratic till 13 min followed by return to initial conditions by $15 \mathrm{~min}$. Compound purity was assigned on the basis of UV detection data at 254-nM detection by comparing relative peak areas of the signals. All final compounds were more than $95 \%$ pure. 
General procedure for ester hydrolysis using $\mathrm{K}_{2} \mathrm{CO}_{3}$ (method A)-To a solution of ester $(0.25 \mathrm{mmol})$ in $\mathrm{MeOH}(4 \mathrm{~mL})$ was added aqueous $\mathrm{K}_{2} \mathrm{CO}_{3}(0.4 \mathrm{~mL}, 2.0 \mathrm{M})$ dropwise. The reaction mixture was stirred at $80^{\circ} \mathrm{C}$ for 1 hour. Completion of reaction was assessed by TLC. The reaction was then cooled $\left(0{ }^{\circ} \mathrm{C}\right)$, acidified to $\mathrm{pH} 2$ with $1.0 \mathrm{~N} \mathrm{HCl}$, and extracted with EtOAc $(3 \times 10 \mathrm{~mL})$. The combined organic phases were dried $\left(\mathrm{MgSO}_{4}\right)$ and concentrated under reduced pressure.

General procedure for ester hydrolysis using LiOH (method B)-To a solution of the ester $(0.11 \mathrm{mmol})$ in anhydrous THF $(0.5 \mathrm{~mL})$ was added aqueous $\mathrm{LiOH}(0.25 \mathrm{~mL}, 1.0$ $\mathrm{N})$ dropwise. The reaction mixture was refluxed for 2 hours or stirred overnight at room temperature. The reaction was then cooled $\left(0^{\circ} \mathrm{C}\right)$, acidified to $\mathrm{pH} 2$ with $1.0 \mathrm{~N} \mathrm{HCl}$, and extracted with EtOAc $(3 \times 10 \mathrm{~mL})$. The combined organic phases were dried $\left(\mathrm{MgSO}_{4}\right)$ and concentrated.

General procedure for Friedel-Crafts acylation (method C) -Acyl chloride (11.7 $\mathrm{mmol})$ and 1,1,4,4-tetramethyl-1,2,3,4-tetrahydronaphthalene material $(2.0 \mathrm{~g}, 10.6 \mathrm{mmol})$ were weighed into a round-bottomed flask equipped with a stir bar and $24 \mathrm{~mL}$ dichloromethane added. Stirring commenced and $\mathrm{AlCl}_{3}(3.10 \mathrm{~g}, 23.3 \mathrm{mmol})$ was added slowly. After completion of the addition, stirring was continued at room temperature overnight. The reaction was then poured into an ice solution $(40 \mathrm{~mL})$, acidified with a $20 \%$ $\mathrm{HCl}$ solution $(10 \mathrm{~mL})$ and the organic layer removed. Then extracted further with $2 \times 40 \mathrm{~mL}$ EtOAc. The organic layers were combined and washed with water $(40 \mathrm{~mL})$ and brine respectively, dried over $\mathrm{MgSO}_{4}$, filtered and concentrated under reduced pressure.

General procedure for formation of dioxolane (method D)—Diarylketone (2.0 mmol) was treated with ethylene glycol $(2 \mathrm{~mL})$ and a catalytic amount of $p \mathrm{TsOH}(20 \mathrm{mg})$ in toluene $(10 \mathrm{~mL})$ at $145^{\circ} \mathrm{C}$ overnight using a Dean Stark trap. After cooling to room temperature, the mixture was washed with saturated $\mathrm{NaHCO}_{3}$ (aq.), brine, dried over $\mathrm{MgSO}_{4}$ and concentrated under reduced pressure.

General procedure for formation of dithiolane (method E)-To a solution of diarylketone $(1.14 \mathrm{mmol})$ in $\mathrm{CH}_{2} \mathrm{Cl}_{2}(2 \mathrm{~mL})$ at $0^{\circ} \mathrm{C}$ under argon, was added a solution of $\left(\mathrm{CH}_{2} \mathrm{SH}\right)_{2}(144 \mu \mathrm{L}, 1.71 \mathrm{mmol})$ in $\mathrm{CH}_{2} \mathrm{Cl}_{2}(0.5 \mathrm{~mL})$ followed by $\mathrm{BF}_{3} \cdot \mathrm{Et}_{2} \mathrm{O}(217 \mu \mathrm{L}, 1.71$ $\mathrm{mmol}$ ). The resulting mixture was stirred at $0^{\circ} \mathrm{C}$ for $1 \mathrm{~h}$ and then warmed to room temperature overnight. The reaction was quenched by pouring the mixture into saturated $\mathrm{NaHCO}_{3}$, and the mixture was extracted with $20 \mathrm{~mL} \mathrm{CH}_{2} \mathrm{Cl}_{2}$. The combined organic layers were dried $\left(\mathrm{MgSO}_{4}\right)$ and concentrated.

\section{General procedure for hydrogenation or hydrogenolysis (method F)—Alkene}

(515 mg, $1.36 \mathrm{mmol}$ ) was placed in a hydrogenation apparatus equipped with a magnetic stir bar and EtOH/EtOAc $(30 \mathrm{~mL})$ added followed by $\mathrm{Pd} / \mathrm{C}(240 \mathrm{mg})$. $\mathrm{H}_{2}$ gas was introduced at $20 \mathrm{psi}$ pressure and reacted at room temperature for $7 \mathrm{hrs}$. The black solution was filtered using a celite pad and concentrated under reduced pressure.

General procedure for coupling thioaryl to aryl halides (method G)—To a mixture of thioaryl $(0.71 \mathrm{mmol}, 1$ eq.) and aryl halides $(0.71 \mathrm{mmol}, 1 \mathrm{eq}$.) in dioxane $(5 \mathrm{~mL})$ 
and butanol $(5 \mathrm{~mL})$, were added the borohydride, polymer supported $(650 \mathrm{mg}, 2.5-5$ $\mathrm{mmol} / \mathrm{g}, 3 \mathrm{eq}$.) and (bpy) ${ }_{2} \mathrm{NiBr}_{2}\left(70 \mathrm{mg}, 0.2 \mathrm{eq}\right.$.). The mixture was heated to $145^{\circ} \mathrm{C}$ under an atmosphere of nitrogen. The polymer beads were removed by filtration, and the mixture was concentrated to dryness before purification by flash chromatography using the following gradient system, (cyclohexane/dichloromethane): (20/80) to (0/100).

General procedure for oxidation of sulfide to sulfone (method $\mathrm{H}$ )-To a solution sulfide $(0.26 \mathrm{mmol})$ in THF $(7 \mathrm{~mL})$, was added a solution of oxone $(475 \mathrm{mg}, 0.775 \mathrm{mmol}, 3$ eq.) in water $(4 \mathrm{~mL})$. The reaction was stirred overnight at room temperature. Water $(10 \mathrm{~mL})$ was added and the mixture was extracted with dichloromethane $(3 \times 50 \mathrm{~mL})$.

\section{Methyl-4-(2-oxo-2-(5,5,8,8-tetramethyl-5,6,7,8-tetrahydronaphthalen-2-} yl)ethoxy)benzoate (4): A mixture $500 \mathrm{mg}(1.62 \mathrm{mmol})$ of the commercially available 2bromo-1-(5,5,8,8-tetramethyl-5,6,7,8-tetrahydronaphthalen-2-yl)ethan-1-one, $271 \mathrm{mg}$ of the commercially available methyl 4-hydroxybenzoate $(1.78 \mathrm{mmol})$ and $\mathrm{K}_{2} \mathrm{CO}_{3}(246 \mathrm{mg}, 1.78$ $\mathrm{mmol}$ ) in $10 \mathrm{ml}$ of methyl ethyl ketone was heated 2 times at $100^{\circ} \mathrm{C}$ for 20 minutes in the microwave and then filtered and concentrated on a rotary evaporator under vacuum. The product was purified by crystallization with a (heptane/ethyl acetate: 70/30) solution to give the expected compound $(450 \mathrm{mg} ; 73 \%)$ as a white solid. $\mathrm{mp}=112-114^{\circ} \mathrm{C} .{ }^{1} \mathrm{H}$ NMR $(500$ $\left.\mathrm{MHz}, \mathrm{CDCl}_{3}\right) \delta 7.98(\mathrm{~d}, J=8.9 \mathrm{~Hz}, 2 \mathrm{H}), 7.97(\mathrm{~d}, J=1.9 \mathrm{~Hz}, 1 \mathrm{H}), 7.72(\mathrm{dd}, J=8.3,1.9 \mathrm{~Hz}$, $1 \mathrm{H}), 7.43(\mathrm{~d}, J=8.3 \mathrm{~Hz}, 1 \mathrm{H}), 6.95(\mathrm{~d}, J=8.9 \mathrm{~Hz}, 2 \mathrm{H}), 5.32(\mathrm{~s}, 2 \mathrm{H}), 3.88(\mathrm{~s}, 3 \mathrm{H}), 1.71(\mathrm{~s}$, $4 \mathrm{H}), 1.32(\mathrm{~s}, 6 \mathrm{H}), 1.31$ (s, 6H). ${ }^{13} \mathrm{C}$ NMR $\left(126 \mathrm{MHz}, \mathrm{CDCl}_{3}\right) \delta 193.34,166.63,161.72$, 152.00, 145.85, 131.74, 131.58, 127.14, 126.68, 125.02, 123.32, 114.32, 70.48, 51.87, 34.80, 34.70, 34.58, 34.42, 31.73, 31.53. MS (TOF ESI+): $\mathrm{m} / \mathrm{z}$ calcd for $\mathrm{C}_{24} \mathrm{H}_{29} \mathrm{O}_{4}{ }^{+}(\mathrm{M}$ $+\mathrm{H})^{+}$calcd. 381.21, found 381.20 .

4-(2-Oxo-2-(5,5,8,8-tetramethyl-5,6,7,8-tetrahydronaphthalen-2-yl)ethoxy)benzoic acid (5): Compound $4(200 \mathrm{mg}, 0.53 \mathrm{mmol})$ was stirred at $80^{\circ} \mathrm{C}$ with sodium hydroxide $(200 \mathrm{mg})$ in a mixture of EtOH, THF and water $(10 \mathrm{~mL}, 10 \mathrm{~mL}$ and $1.5 \mathrm{~mL})$ for 12 hours. The reaction was then cooled at r.t., acidified to $\mathrm{pH} 2$ with $1.0 \mathrm{~N} \mathrm{HCl}$, and extracted with EtOAc $(3 \times 20 \mathrm{~mL})$. The combined organic phases were dried $\left(\mathrm{MgSO}_{4}\right)$ and concentrated under reduced pressure. The residue was purified by crystallization in a mixture of heptane and EtOAc (70/30) to provide $149 \mathrm{mg}(77 \%)$ of a white solid. $\mathrm{mp}=162-163^{\circ} \mathrm{C} .{ }^{1} \mathrm{H}$ NMR $(400$ $\left.\mathrm{MHz}, \mathrm{CDCl}_{3}\right) \delta 8.06(\mathrm{~d}, J=8.9 \mathrm{~Hz}, 2 \mathrm{H}), 7.98(\mathrm{~d}, J=1.7 \mathrm{~Hz}, 1 \mathrm{H}), 7.72(\mathrm{dd}, J=8.3,1.8 \mathrm{~Hz}$, $1 \mathrm{H}), 7.43(\mathrm{~d}, J=8.3 \mathrm{~Hz}, 1 \mathrm{H}), 6.97(\mathrm{~d}, J=8.9 \mathrm{~Hz}, 2 \mathrm{H}), 5.34(\mathrm{~s}, 2 \mathrm{H}), 1.72(\mathrm{~s}, 4 \mathrm{H}), 1.32(\mathrm{~s}$, $6 \mathrm{H}), 1.31(\mathrm{~s}, 6 \mathrm{H}) .{ }^{13} \mathrm{C} \mathrm{NMR}\left(101 \mathrm{MHz}, \mathrm{CDCl}_{3}\right) \delta 193.30,170.88,162.50,152.11,145.95$, 132.40, 131.80, 127.21, 126.77, 125.07, 122.38, 114.51, 70.56, 34.86, 34.77, 34.66, 34.47, 31.77, 31.57. HPLC ( $\mathrm{t}=8.12 \mathrm{~min}, 96 \%)$. MS (TOF ESI+) for $\mathrm{C}_{23} \mathrm{H}_{27} \mathrm{O}_{4}{ }^{+}(\mathrm{M}+\mathrm{H})^{+}$calcd. 367.20, found 367.19 .

\section{4-(2-Hydroxy-2-(5,5,8,8-tetramethyl-5,6,7,8-tetrahydronaphthalen-2-yl)ethoxy)benzoic} acid (6): To a solution of compound $495 \mathrm{mg}(0,25 \mathrm{mmole})$ dissolved in $3 \mathrm{~mL}$ of THF under nitrogen, was carefully added $10 \mathrm{mg}$ of sodium borohydride $(0,25 \mathrm{mmole})$. The mixture was stirred $3 \mathrm{~h}$ at room temperature. The residue was taken up in $10 \mathrm{~mL}$ water, and the aqueous layer was extracted with $3 \times 10 \mathrm{~mL}$ EtOAc. The combined organic extract was washed with 
$30 \mathrm{~mL}$ water and $30 \mathrm{~mL}$ brine respectively. The organic solution was dried $\left(\mathrm{MgSO}_{4}\right)$, filtered, and concentrated to give $75 \mathrm{mg}(79 \%)$ of a colorless oil. The resulting ester (70 mg, $0.18 \mathrm{mmol}$ ) was stirred at $80^{\circ} \mathrm{C}$ with sodium hydroxide $(70 \mathrm{mg})$ in a mixture of EtOH, THF and water $(3 \mathrm{~mL}, 3 \mathrm{~mL}$ and $0.5 \mathrm{~mL})$ for 12 hours. The reaction was then cooled at r.t., acidified to $\mathrm{pH} 2$ with $1.0 \mathrm{~N} \mathrm{HCl}$, and extracted with EtOAc $(3 \times 10 \mathrm{~mL})$. The combined organic phases were dried $\left(\mathrm{MgSO}_{4}\right)$ and concentrated under reduced pressure. The residue was purified by crystallization in a mixture of heptane and EtOAc (70/30) to provide $40 \mathrm{mg}$ $(60 \%)$ of a white solid. $\mathrm{mp}=156-158^{\circ} \mathrm{C} .{ }^{1} \mathrm{H}$ NMR $\left(400 \mathrm{MHz}, \mathrm{CDCl}_{3}\right) \delta 8.06(\mathrm{~d}, J=8.8 \mathrm{~Hz}$, 2H), $7.38(\mathrm{~d}, J=1.5 \mathrm{~Hz}, 1 \mathrm{H}), 7.34(\mathrm{~d}, J=8.1 \mathrm{~Hz}, 1 \mathrm{H}), 7.21(\mathrm{dd}, J=8.1,1.6 \mathrm{~Hz}, 1 \mathrm{H}), 6.97$ (d, $J=8.9 \mathrm{~Hz}, 2 \mathrm{H}), 5.11(\mathrm{dd}, J=8.3,3.4 \mathrm{~Hz}, 1 \mathrm{H}), 4.23-4.04(\mathrm{~m}, 2 \mathrm{H}), 1.69(\mathrm{~s}, 4 \mathrm{H}), 1.35-$ $1.22(\mathrm{~m}, 12 \mathrm{H}) .{ }^{13} \mathrm{C}$ NMR $\left(101 \mathrm{MHz}, \mathrm{CDCl}_{3}\right) \delta 171.39,162.97,145.28,145.17,136.35$, $132.39,126.92,124.46,123.41,122.09,114.37,73.45,72.63,35.07,34.99,34.35,34.19$, 31.87, 31.85, 31.83. HPLC ( $\mathrm{t}=8.34 \mathrm{~min}, 97 \%)$. MS (TOF ESI+) for $\mathrm{C}_{23} \mathrm{H}_{29} \mathrm{O}_{4}{ }^{+}(\mathrm{M}+\mathrm{H})^{+}$ calcd. 369.21, found 369.21.

(E)-Methyl-4-(2-(hydroxyimino)-2-(5,5,8,8-tetramethyl-5,6,7,8tetrahydronaphthalen-2-yl)ethoxy-)benzoate (7): The E-isomer was recrystallized from EtOAc/heptane (3/7) to give $69 \mathrm{mg}(24 \%)$ of a white solid. $\mathrm{mp}=146-149^{\circ} \mathrm{C} .{ }^{1} \mathrm{H}$ NMR $(500$ $\left.\mathrm{MHz}, \mathrm{CDCl}_{3}\right) \delta 8.21(\mathrm{~s}, 1 \mathrm{H}), 7.98(\mathrm{~d}, J=9.0 \mathrm{~Hz}, 2 \mathrm{H}), 7.59$ (d, $\left.J=1.8 \mathrm{~Hz}, 1 \mathrm{H}\right), 7.40$ (dd, $J=$ $8.3,1.9 \mathrm{~Hz}, 1 \mathrm{H}), 7.35(\mathrm{~d}, J=8.3 \mathrm{~Hz}, 1 \mathrm{H}), 6.98(\mathrm{~d}, J=9.0 \mathrm{~Hz}, 2 \mathrm{H}), 4.95(\mathrm{~s}, 2 \mathrm{H}), 3.88$ (s, $3 \mathrm{H}), 1.69(\mathrm{~s}, 4 \mathrm{H}), 1.28(\mathrm{~s}, 6 \mathrm{H}), 1.25(\mathrm{~s}, 6 \mathrm{H}) .{ }^{13} \mathrm{C} \mathrm{NMR}\left(126 \mathrm{MHz}, \mathrm{CDCl}_{3}\right) \delta 166.79,161.93$, 153.08, 146.73, 144.85, 131.56, 127.49, 126.93, 126.48, 125.51, 123.11, 114.55, 69.32, $51.91,34.88,34.83,34.34,34.29,31.78,31.65$. MS (TOF ESI+) for $\mathrm{C}_{24} \mathrm{H}_{30} \mathrm{NO}_{4}{ }^{+}(\mathrm{M}+\mathrm{H})^{+}$ calcd. 396.22, found 396.21 .

(Z)-Methyl-4-(2-(hydroxyimino)-2-(5,5,8,8-tetramethyl-5,6,7,8tetrahydronaphthalen-2-yl)ethoxy-)benzoate (8): A solution of compound $5(275 \mathrm{mg}$, $0.72 \mathrm{mmol})$ in $\mathrm{MeOH}(7 \mathrm{~mL})$ was treated with hydroxylamine hydrochloride (100 mg, 1.45 mmol) and pyridine $(235 \mu \mathrm{L}, 2.9 \mathrm{mmol})$, and the mixture was heated at reflux for $6 \mathrm{~h}$. The mixture was cooled to room temperature, and the $\mathrm{MeOH}$ was removed in vacuo. The residue was taken up in $20 \mathrm{~mL}$ water, and the aqueous layer was extracted with $3 \times 30 \mathrm{~mL}$ EtOAc. The combined organic extract was washed with $20 \mathrm{~mL}$ water and $20 \mathrm{~mL}$ brine respectively. The organic solution was dried $\left(\mathrm{MgSO}_{4}\right)$, filtered, and concentrated. The residue was purified by flash column chromatography (heptane-ethyl acetate 100:0 v/v increasing to $70: 30 \mathrm{v} / \mathrm{v}$ )to yield the 2 isomers $\mathrm{E}$ and $\mathrm{Z}$. The Z-isomer was recrystallized from EtOAc/ heptane to give $165 \mathrm{mg}(71 \%)$ of a white solid. $\mathrm{mp}=123-125^{\circ} \mathrm{C} .{ }^{1} \mathrm{H}$ NMR $(500 \mathrm{MHz}$, $\left.\mathrm{CDCl}_{3}\right) \delta 8.79(\mathrm{~s}, 1 \mathrm{H}), 7.97(\mathrm{~d}, J=8.8 \mathrm{~Hz}, 2 \mathrm{H}), 7.60(\mathrm{~d}, J=1.9 \mathrm{~Hz}, 1 \mathrm{H}), 7.39(\mathrm{dd}, J=8.3$, $1.9 \mathrm{~Hz}, 1 \mathrm{H}), 7.29(\mathrm{~d}, J=8.3 \mathrm{~Hz}, 1 \mathrm{H}), 6.98(\mathrm{~d}, J=8.8 \mathrm{~Hz}, 2 \mathrm{H}), 5.32(\mathrm{~s}, 2 \mathrm{H}), 3.88(\mathrm{~s}, 3 \mathrm{H})$, 1.67 (s, 4H), 1.27 (s, 6H), 1.26 (s, 6H). ${ }^{13} \mathrm{C}$ NMR $\left(126 \mathrm{MHz}, \mathrm{CDCl}_{3}\right) \delta 166.81,161.81$, 155.20, 146.73, 144.91, 131.59, 130.12, 126.69, 125.35, 124.01, 123.09, 114.25, 59.86, 51.91, 34.93, 34.85, 34.30, 34.29, 31.78, 31.65. MS (TOF ESI+) for $\mathrm{C}_{24} \mathrm{H}_{30} \mathrm{NO}_{4}{ }^{+}(\mathrm{M}+\mathrm{H})^{+}$ calcd. 396.22, found 396.21 .

(Z)-4-(2-(Hydroxyimino)-2-(5,5,8,8-tetramethyl-5,6,7,8-tetrahydronaphthalen-2yl)ethoxy)benzoic acid (9): Compound $8(100 \mathrm{mg}, 0.25 \mathrm{mmol})$ was hydrolysed according 
to method A. The residue was purified by flash column chromatography (DCM-MeOH 100:0 v/v increasing to $95: 5 \mathrm{v} / \mathrm{v})$ to provide a white solid $(25 \mathrm{mg}, 27 \%) . \mathrm{mp}=208-$ $211^{\circ} \mathrm{C} .{ }^{1} \mathrm{H} \mathrm{NMR}\left(500 \mathrm{MHz}, \mathrm{CDCl}_{3}\right) \delta 7.96(\mathrm{~d}, J=8.9 \mathrm{~Hz}, 2 \mathrm{H}), 7.58(\mathrm{~d}, J=1.9 \mathrm{~Hz}, 1 \mathrm{H})$, $7.48(\mathrm{~s}, 1 \mathrm{H}), 7.39$ (dd, $J=8.3,1.9 \mathrm{~Hz}, 1 \mathrm{H}), 7.28(\mathrm{~d}, J=8.3 \mathrm{~Hz}, 1 \mathrm{H}), 6.99$ (d, $J=8.9 \mathrm{~Hz}$, 2H), $5.33(\mathrm{~s}, 2 \mathrm{H}), 1.68(\mathrm{~s}, 4 \mathrm{H}), 1.26(\mathrm{~s}, 6 \mathrm{H}), 1.25(\mathrm{~s}, 6 \mathrm{H})$. HPLC (t= $8.14 \mathrm{~min}, 95 \%)$. HRMS (TOF ESI+) for $\mathrm{C}_{23} \mathrm{H}_{28} \mathrm{NO}_{4}{ }^{+}(\mathrm{M}+\mathrm{H})^{+}$calcd. 382.2018, found 382.2012.

Methyl-4-(5,5,8,8-tetramethyl-5,6,7,8-tetrahydronaphthalene-2-carbonyl)benzoate (10a): Compound 10a was prepared according to method $\mathrm{C}$ starting from $2.0 \mathrm{~g}$ of the commercially available 1,1,4,4-tetramethyl-1,2,3,4-tetrahydronaphthalene (10.6 mmol). The crude was crystallized from hot EtOAc by addition of $20 \mathrm{~mL} \mathrm{MeOH}$, resulting in white crystals after cooling. Yield $2.15 \mathrm{~g}(58 \%) . \mathrm{mp}=140-142^{\circ} \mathrm{C} .{ }^{1} \mathrm{H} \mathrm{NMR}\left(400 \mathrm{MHz}, \mathrm{CDCl}_{3}\right) \delta$ $8.15(\mathrm{~d}, J=8.4 \mathrm{~Hz}, 2 \mathrm{H}), 7.83(\mathrm{~d}, J=8.4 \mathrm{~Hz}, 2 \mathrm{H}), 7.79$ (d, $J=1.8 \mathrm{~Hz}, 1 \mathrm{H}), 7.54$ (dd, $J=8.2$, $1.9 \mathrm{~Hz}, 1 \mathrm{H}), 7.41(\mathrm{~d}, J=8.2 \mathrm{~Hz}, 1 \mathrm{H}), 3.97$ (s, 3H), $1.72(\mathrm{~s}, 4 \mathrm{H}), 1.32$ (s, 6H), 1.29 (s, $6 \mathrm{H}) .{ }^{13} \mathrm{C} \mathrm{NMR}\left(101 \mathrm{MHz}, \mathrm{CDCl}_{3}\right) \delta 195.88,166.40,150.78,145.30,141.88,134.15$, 132.91, 129.67, 129.39, 128.89, 127.35, 126.70, 52.40, 34.81, 34.74, 34.41, 31.74, 31.60. MS (TOF ESI+) for $\mathrm{C}_{23} \mathrm{H}_{27} \mathrm{O}_{3}{ }^{+}(\mathrm{M}+\mathrm{H})^{+}$calcd. 351.20, found 351.20.

Methyl-6-(5,5,8,8-tetramethyl-5,6,7,8-tetrahydronaphthalene-2-carbonyl)-2-naphthoate (10b): Compound 10b was synthesized according to method $\mathrm{C}$ starting from $875 \mathrm{mg}$ of 1,1,4,4-tetramethyl-1,2,3,4-tetrahydronaphthalene (4.65 mmol). The compound $\mathbf{1 0 b}$ crystallized from hot EtOAc by addition of $20 \mathrm{~mL} \mathrm{MeOH}$, resulting in white crystals after cooling (1.94 g, 69\%). $\mathrm{mp}=134-136^{\circ} \mathrm{C} .{ }^{1} \mathrm{H} \mathrm{NMR}\left(400 \mathrm{MHz}, \mathrm{CDCl}_{3}\right) \delta 8.67(\mathrm{~s}, 1 \mathrm{H}), 8.30$ $(\mathrm{s}, 1 \mathrm{H}), 8.13(\mathrm{dd}, J=8.6,1.6 \mathrm{~Hz}, 1 \mathrm{H}), 8.06(\mathrm{~d}, J=8.5 \mathrm{~Hz}, 1 \mathrm{H}), 7.98(\mathrm{dd}, J=8.5,1.6 \mathrm{~Hz}$, 2H), 7.97 (d, $J=8.6 \mathrm{~Hz}, 1 \mathrm{H}), 7.87$ (d, $J=1.8 \mathrm{~Hz}, 1 \mathrm{H}), 7.60(\mathrm{dd}, J=8.2,1.8 \mathrm{~Hz}, 1 \mathrm{H}), 7.44$ $(\mathrm{d}, J=8.2 \mathrm{~Hz}, 1 \mathrm{H}), 4.01(\mathrm{~s}, 3 \mathrm{H}), 1.74(\mathrm{~s}, 4 \mathrm{H}), 1.34(\mathrm{~s}, 6 \mathrm{H}), 1.31(\mathrm{~s}, 6 \mathrm{H}) .{ }^{13} \mathrm{C} \mathrm{NMR}(101$ $\left.\mathrm{MHz}, \mathrm{CDCl}_{3}\right) \delta 196.21,166.86,150.47,145.26,137.33,134.59,134.45,134.13,130.91$, $130.68,129.49,129.33,128.94,127.44,126.69,126.66,126.08,52.40,34.85,34.78,34.73$, 34.43, 31.76, 31.63. MS (TOF ESI+) for $\mathrm{C}_{27} \mathrm{H}_{29} \mathrm{O}_{3}{ }^{+}(\mathrm{M}+\mathrm{H})^{+}$calcd. 401.21, found 401.21.

4-(5,5,8,8-Tetramethyl-5,6,7,8-tetrahydronaphthalene-2-carbonyl)benzoic acid (11a): Compound 10a (60 mg, $0.17 \mathrm{mmol})$ was hydrolyzed according to method A. The resultant oil was triturated with heptanes to yield compound 11 as a white solid $(52 \mathrm{mg}, 91 \%)$. $\mathrm{mp}=$ 194-195 ${ }^{\circ} \mathrm{C} .{ }^{1} \mathrm{H} \mathrm{NMR}\left(400 \mathrm{MHz}, \mathrm{CDCl}_{3}\right) \delta 8.24(\mathrm{~d}, J=8.3 \mathrm{~Hz}, 2 \mathrm{H}), 7.87(\mathrm{~d}, J=8.3 \mathrm{~Hz}$, $2 \mathrm{H}), 7.81(\mathrm{~d}, J=1.8 \mathrm{~Hz}, 1 \mathrm{H}), 7.55(\mathrm{dd}, J=8.2,1.8 \mathrm{~Hz}, 1 \mathrm{H}), 7.42(\mathrm{~d}, J=8.2 \mathrm{~Hz}, 1 \mathrm{H}), 1.73$ (s, 4H), 1.33 (s, 6H), 1.30 (s, 6H). $\left.{ }^{13} \mathrm{C} \mathrm{NMR} \mathrm{(101} \mathrm{MHz,} \mathrm{CDCl}_{3}\right) \delta 195.84,170.91,150.97$, $145.41,142.74,134.03,131.89,130.05,129.75,128.91,127.42,126.76,34.81,34.77$, 34.74, 34.43, 31.76, 31.61, 26.91. HPLC ( $\mathrm{t}=8.82 \mathrm{~min}, 100 \%)$. HRMS (TOF ESI+) for $\mathrm{C}_{22} \mathrm{H}_{25} \mathrm{O}_{3}+(\mathrm{M}+\mathrm{H})^{+}$calcd. 337.1804, found 337.1811.

\section{6-(5,5,8,8-Tetramethyl-5,6,7,8-tetrahydronaphthalene-2-carbonyl)-2-naphthoic acid} (11b): Compound $10 b(220 \mathrm{mg}, 0.55 \mathrm{mmol})$ was hydrolyzed according to method A. The crude was crystalized from cyclohexane to provide compound $\mathbf{1 1 b}$ as a white solid (90 $\mathrm{mg}$, $95 \%) . \mathrm{mp}=224-225^{\circ} \mathrm{C} .{ }^{1} \mathrm{H}$ NMR $(400 \mathrm{MHz}, \mathrm{MeOD}) \delta 8.70(\mathrm{~s}, 1 \mathrm{H}), 8.30(\mathrm{~s}, 1 \mathrm{H}), 8.15(\mathrm{~d}, J$ $=8.5 \mathrm{~Hz}, 1 \mathrm{H}), 8.08(\mathrm{~d}, J=8.5 \mathrm{~Hz}, 1 \mathrm{H}), 7.98(\mathrm{t}, J=8.0 \mathrm{~Hz}, 2 \mathrm{H}), 7.86(\mathrm{~s}, 1 \mathrm{H}), 7.61(\mathrm{~d}, J=8.2$ 
$\mathrm{Hz}, 1 \mathrm{H}), 7.46$ (d, $J=8.2 \mathrm{~Hz}, 1 \mathrm{H}), 1.75(\mathrm{~s}, 4 \mathrm{H}), 1.35$ (s, 6H), 1.32 (s, 6H). ${ }^{13} \mathrm{C}$ NMR $(101$ MHz, MeOD) $\delta$ 196.84, 168.40, 150.59, 145.17, 136.98, 134.34, 134.32, 134.12, 130.94, $130.80,129.70,129.45,129.30,128.88,127.30,126.59,126.33,126.27,34.65,34.58$, $34.26,31.53,31.40$. HPLC $(\mathrm{t}=9.40 \mathrm{~min}, 95 \%)$. HRMS (TOF ESI + ) for $\mathrm{C}_{26} \mathrm{H}_{27} \mathrm{O}_{3}{ }^{+}(\mathrm{M}+\mathrm{H})^{+}$ calcd. 387.1960, found 387.1998.

Methyl-4-(2-(5,5,8,8-tetramethyl-5,6,7,8-tetrahydronaphthalen-2-yl)-1,3-dioxolan-2yl)benzoate (12a): Compound 10a (705 mg, $2.01 \mathrm{mmol})$ was treated treated according to method D. After work-up, the residue was purified by flash column chromatography (cyclohexane-EtOAc 100:0 v/v increasing to $60: 40 \mathrm{v} / \mathrm{v}$ ) to yield a white solid, $641 \mathrm{mg}$ (81\%). mp $=148-148^{\circ} \mathrm{C} .{ }^{1} \mathrm{H} \mathrm{NMR}\left(400 \mathrm{MHz}, \mathrm{CDCl}_{3}\right) \delta 8.00(\mathrm{~d}, J=8.3 \mathrm{~Hz}, 2 \mathrm{H}), 7.61(\mathrm{~d}, J$ $=8.3 \mathrm{~Hz}, 2 \mathrm{H}), 7.42(\mathrm{~d}, J=1.8 \mathrm{~Hz}, 1 \mathrm{H}), 7.23(\mathrm{~d}, J=8.3 \mathrm{~Hz}, 1 \mathrm{H}), 7.17(\mathrm{dd}, J=8.2,1.8 \mathrm{~Hz}$, $1 \mathrm{H}), 4.14-4.07(\mathrm{~m}, 2 \mathrm{H}), 4.07-3.97(\mathrm{~m}, 2 \mathrm{H}), 3.90(\mathrm{~s}, 3 \mathrm{H}), 1.65(\mathrm{~s}, 4 \mathrm{H}), 1.23(\mathrm{~s}, 12 \mathrm{H}) .{ }^{13} \mathrm{C}$ NMR (101 MHz, $\left.\mathrm{CDCl}_{3}\right) \delta 166.88,147.43,144.86,144.65,138.21,129.61,129.47,126.45$, $126.17,123.82,123.25,109.22,64.90,52.07,35.04,34.99,34.31,34.09,31.83,31.76$. MS (TOF ESI+) for $\mathrm{C}_{25} \mathrm{H}_{31} \mathrm{O}_{4}{ }^{+}(\mathrm{M}+\mathrm{H})^{+}$calcd. 395.22, found 395.23.

Methyl-6-(2-(5,5,8,8-tetramethyl-5,6,7,8-tetrahydronaphthalen-2-yl)-1,3-dioxolan-2yl)-2-naphthoate (12b): Compound 11b $(570 \mathrm{mg}, 1.42 \mathrm{mmol})$ was treated according to method $\mathrm{D}$. The residue was purified by flash column chromatography (cyclohexane-EtOAc $100: 0 \mathrm{v} / \mathrm{v}$ increasing to $60: 40 \mathrm{v} / \mathrm{v})$ to yield a white solid $(557 \mathrm{mg}, 88 \%) . \mathrm{mp}=182$ $184^{\circ} \mathrm{C} .{ }^{1} \mathrm{H}$ NMR $\left(400 \mathrm{MHz}, \mathrm{CDCl}_{3}\right) \delta 8.57(\mathrm{~s}, 1 \mathrm{H}), 8.07$ (s, $\left.1 \mathrm{H}\right), 8.05(\mathrm{dd}, J=8.6,1.5 \mathrm{~Hz}$, $1 \mathrm{H}), 7.89(\mathrm{dd}, J=8.5,5.1 \mathrm{~Hz}, 2 \mathrm{H}), 7.67(\mathrm{dd}, J=8.6,1.6 \mathrm{~Hz}, 1 \mathrm{H}), 7.52(\mathrm{~s}, 1 \mathrm{H}), 7.24(\mathrm{~d}, J=$ $9.1 \mathrm{~Hz}, 2 \mathrm{H}), 4.19-4.11(\mathrm{~m}, 2 \mathrm{H}), 4.11-4.02(\mathrm{~m}, 2 \mathrm{H}), 3.97(\mathrm{~s}, 3 \mathrm{H}), 1.65(\mathrm{~s}, 4 \mathrm{H}), 1.25(\mathrm{~s}$, $6 \mathrm{H}), 1.23$ (s, 6H). ${ }^{13} \mathrm{C} \mathrm{NMR}\left(101 \mathrm{MHz}, \mathrm{CDCl}_{3}\right) \delta 167.22,144.81,144.63,142.46,138.37$, $135.12,132.07,130.67,129.38,128.63,127.59,126.45,125.43,125.35,124.55,123.85$, $123.47,109.51,64.98,52.20,35.06,35.00,34.32,34.10,31.85,31.77$. MS (TOF ESI+) for $\mathrm{C}_{29} \mathrm{H}_{33} \mathrm{O}_{4}+(\mathrm{MH}+)$ calcd. 445.24, found 445.23.

\section{4-(2-(5,5,8,8-Tetramethyl-5,6,7,8-tetrahydronaphthalen-2-yl)-1,3-dioxolan-2-yl)benzoic} acid (13a): Compound 12a (236 mg, $0.59 \mathrm{mmol}$ ) was hydrolyzed according to method A. The crude was crystalized from cyclohexane and washed to provide compound 13a as a white solid $(161 \mathrm{mg}, 72 \%) . \mathrm{mp}=242-243^{\circ} \mathrm{C} .{ }^{1} \mathrm{H}$ NMR $\left(400 \mathrm{MHz}, \mathrm{CDCl}_{3}\right) \delta 12.05(\mathrm{bs}, 1 \mathrm{H})$, $8.07(\mathrm{~d}, J=8.5 \mathrm{~Hz}, 2 \mathrm{H}), 7.65(\mathrm{~d}, J=8.5 \mathrm{~Hz}, 2 \mathrm{H}), 7.44(\mathrm{~d}, J=1.8 \mathrm{~Hz}, 1 \mathrm{H}), 7.24(\mathrm{~d}, J=8.3$ $\mathrm{Hz}, 1 \mathrm{H}), 7.18(\mathrm{dd}, J=8.3,1.9 \mathrm{~Hz}, 1 \mathrm{H}), 4.15-4.08(\mathrm{~m}, 2 \mathrm{H}), 4.08-3.99(\mathrm{~m}, 2 \mathrm{H}), 1.65(\mathrm{~s}$, $4 \mathrm{H}), 1.24(\mathrm{~s}, 6 \mathrm{H}), 1.23$ (s, 6H). ${ }^{13} \mathrm{C} \mathrm{NMR}\left(101 \mathrm{MHz}, \mathrm{CDCl}_{3}\right) \delta 171.55,148.46,144.93$, 144.72, 138.13, 130.14, 128.67, 126.50, 126.30, 123.79, 123.24, 109.19, 64.94, 35.05, $35.00,34.33,34.11,31.84,31.77$. HPLC ( $\mathrm{t}=8.85 \mathrm{~min}$, 98\%). HRMS (TOF MS ES+) for $\mathrm{C}_{24} \mathrm{H}_{29} \mathrm{O}_{4}{ }^{+}(\mathrm{MH}+)$ calcd. 381.2066, found 381.2038.

6-(2-(5,5,8,8-Tetramethyl-5,6,7,8-tetrahydronaphthalen-2-yl)-1,3-dioxolan-2-yl)-2naphthoic acid (13b): Compound $\mathbf{1 2 b}$ was hydrolyzed according to method B. The crude oil was purified by flash column chromatography (cyclohexane-EtOAc-HOAc 100:0:0.1 v/v increasing to 80:20:0.1 v/v) to provide a white solid $(30 \mathrm{mg}, 63 \%) . \mathrm{mp}=222-223^{\circ} \mathrm{C} .{ }^{1} \mathrm{H}$ NMR $\left(400 \mathrm{MHz}, \mathrm{CDCl}_{3}\right) \delta 8.68(\mathrm{~s}, 1 \mathrm{H}), 8.12(\mathrm{~d}, J=8.6 \mathrm{~Hz}, 2 \mathrm{H}), 7.94(\mathrm{dd}, J=8.5,4.6 \mathrm{~Hz}$, 
2H), $7.70(\mathrm{dd}, J=8.6,1.3 \mathrm{~Hz}, 1 \mathrm{H}), 7.52(\mathrm{~s}, 1 \mathrm{H}), 7.24(\mathrm{~d}, J=6.1 \mathrm{~Hz}, 2 \mathrm{H}), 4.17(\mathrm{~m}, 2 \mathrm{H})$, $4.13-4.03(\mathrm{~m}, 2 \mathrm{H}), 1.65$ (s, 4H), 1.25 (s, 6H), $1.23(\mathrm{~s}, 6 \mathrm{H}) .{ }^{13} \mathrm{C} \mathrm{NMR}\left(101 \mathrm{MHz}, \mathrm{CDCl}_{3}\right) \delta$ $172.09,144.86,144.67,142.95,138.32,135.60,132.02,131.77,129.58,128.82,126.68$, $126.48,125.60,125.52,124.60,123.87,123.46,109.50,65.01,35.06,35.00,34.33,34.11$, 31.85, 31.77. HPLC ( $\mathrm{t}=7.74 \mathrm{~min}, 95 \%)$. HRMS (TOF ESI + ) for $\mathrm{C}_{28} \mathrm{H}_{31} \mathrm{O}_{4}+(\mathrm{M}+\mathrm{H})^{+}$calcd. 431.2222, found 431.2222 .

Methyl-4-(2-(5,5,8,8-tetramethyl-5,6,7,8-tetrahydronaphthalen-2-yl)-1,3-dithiolan-2yl)benzoate (14a): Compound 10a (400 mg, $1.14 \mathrm{mmol}$ ) was treated according to method E. The crude residue was purified by flash column chromatography (cyclohexane-DCM 100:0 $\mathrm{v} / \mathrm{v}$ increasing to $60: 40 \mathrm{v} / \mathrm{v})$ to yield $\mathbf{1 4 a}$ as a white solid $(482 \mathrm{mg}, 99 \%) . \mathrm{mp}=103-$ $105^{\circ} \mathrm{C} .{ }^{1} \mathrm{H}$ NMR $\left(400 \mathrm{MHz}, \mathrm{CDCl}_{3}\right) \delta 7.95(\mathrm{~d}, J=8.7 \mathrm{~Hz}, 2 \mathrm{H}), 7.72(\mathrm{~d}, J=8.6 \mathrm{~Hz}, 2 \mathrm{H})$, $7.45(\mathrm{~d}, J=2.1 \mathrm{~Hz}, 1 \mathrm{H}), 7.22(\mathrm{dd}, J=8.4,2.1 \mathrm{~Hz}, 1 \mathrm{H}), 7.17(\mathrm{~d}, J=8.3 \mathrm{~Hz}, 1 \mathrm{H}), 3.90$ (s, $3 \mathrm{H}), 3.52-3.41(\mathrm{~m}, 2 \mathrm{H}), 3.41-3.30(\mathrm{~m}, 2 \mathrm{H}), 1.65(\mathrm{~s}, 4 \mathrm{H}), 1.24(\mathrm{~s}, 6 \mathrm{H}), 1.20(\mathrm{~s}, 6 \mathrm{H}) .{ }^{13} \mathrm{C}$ NMR (101 MHz, $\left.\mathrm{CDCl}_{3}\right) \delta 166.79,150.39,144.37,144.03,140.08,129.12,128.77,128.37$, 126.24, 125.34, 52.07, 40.23, 35.02, 34.98, 34.33, 34.02, 31.77, 31.71. MS (TOF ESI+) for $\mathrm{C}_{25} \mathrm{H}_{31} \mathrm{O}_{2} \mathrm{~S}_{2}{ }^{+}(\mathrm{M}+\mathrm{H})^{+}$calcd. 427.18, found 427.18.

Methyl-6-(2-(5,5,8,8-tetramethyl-5,6,7,8-tetrahydronaphthalen-2-yl)-1,3-dithiolan-2yl)-2-naphthoate (14b): Compound $\mathbf{1 0 b}(0.83 \mathrm{~g}, 2.07 \mathrm{mmol})$ was treated according to method E. The crude was purified by flash column chromatography (cyclohexane-EtOAc 100:0 $\mathrm{v} / \mathrm{v}$ increasing to $95: 5 \mathrm{v} / \mathrm{v}$ ) to yield $\mathbf{1 4 b}$ as a white solid $(851 \mathrm{mg}, 86 \%)$. $\mathrm{mp}=153-$ $155^{\circ} \mathrm{C} .{ }^{1} \mathrm{H}$ NMR $\left(400 \mathrm{MHz}, \mathrm{CDCl}_{3}\right) \delta 8.55(\mathrm{~s}, 1 \mathrm{H}), 8.24(\mathrm{~d}, J=1.1 \mathrm{~Hz}, 1 \mathrm{H}), 8.06$ (dd, $J=$ $8.6,1.5 \mathrm{~Hz}, 1 \mathrm{H}), 7.87$ (d, $J=8.6 \mathrm{~Hz}, 1 \mathrm{H}), 7.84(\mathrm{~d}, J=8.8 \mathrm{~Hz}, 1 \mathrm{H}), 7.67$ (dd, $J=8.7,1.9 \mathrm{~Hz}$, $1 \mathrm{H}), 7.53(\mathrm{~d}, J=2.1 \mathrm{~Hz}, 1 \mathrm{H}), 7.24(\mathrm{dd}, J=8.6,1.5 \mathrm{~Hz}, 1 \mathrm{H}), 7.18(\mathrm{~d}, J=8.4 \mathrm{~Hz}, 1 \mathrm{H}), 3.97$ $(\mathrm{s}, 3 \mathrm{H}), 3.57-3.45(\mathrm{~m}, 2 \mathrm{H}), 3.44-3.33(\mathrm{~m}, 2 \mathrm{H}), 1.65(\mathrm{~s}, 4 \mathrm{H}), 1.25(\mathrm{~s}, 6 \mathrm{H}), 1.19(\mathrm{~s}$, $6 \mathrm{H}) .{ }^{13} \mathrm{C} \mathrm{NMR}\left(101 \mathrm{MHz}, \mathrm{CDCl}_{3}\right) \delta 167.23,145.05,144.41,144.06,139.86,134.81$, $131.49,130.38,128.91,128.60,128.24,127.64,126.36,126.26,125.92,125.63,125.53$, $52.20,40.18,35.05,35.01,34.35,34.04,31.77,31.73$. MS (TOF ESI+) for $\mathrm{C}_{29} \mathrm{H}_{33} \mathrm{O}_{2} \mathrm{~S}_{2}{ }^{+}$ $(\mathrm{M}+\mathrm{H})^{+}$calcd. 477.20, found 477.19 .

4-(2-(5,5,8,8-Tetramethyl-5,6,7,8-tetrahydronaphthalen-2-yl)-1,3-dithiolan-2-yl)benzoic acid (15a): Compound 14a (100 mg, $0.23 \mathrm{mmol})$ in $\mathrm{MeOH}(5 \mathrm{~mL})$ was hydrolyzed according to method $\mathrm{A}$. The crude was crystalized from cyclohexane to provide compound 15a as a white solid $(90 \mathrm{mg}, 95 \%) . \mathrm{mp}=211-212^{\circ} \mathrm{C} .{ }^{1} \mathrm{H} \mathrm{NMR}\left(400 \mathrm{MHz}, \mathrm{CDCl}_{3}\right) \delta 8.03$ (d, $J=8.6 \mathrm{~Hz}, 2 \mathrm{H}), 7.76(\mathrm{~d}, J=8.6 \mathrm{~Hz}, 2 \mathrm{H}), 7.46(\mathrm{~d}, J=2.0 \mathrm{~Hz}, 1 \mathrm{H}), 7.22(\mathrm{dd}, J=8.4,2.1$ $\mathrm{Hz}, 1 \mathrm{H}), 7.18(\mathrm{~d}, J=8.3 \mathrm{~Hz}, 1 \mathrm{H}), 3.53-3.43(\mathrm{~m}, 2 \mathrm{H}), 3.42-3.32(\mathrm{~m}, 2 \mathrm{H}), 1.65(\mathrm{~s}, 4 \mathrm{H})$, $1.25(\mathrm{~s}, 6 \mathrm{H}), 1.20(\mathrm{~s}, 6 \mathrm{H}) .{ }^{13} \mathrm{C} \mathrm{NMR}\left(101 \mathrm{MHz}, \mathrm{CDCl}_{3}\right) \delta 171.58,151.50,144.44,144.10$, 139.98, 129.80, 128.49, 127.83, 126.30, 126.21, 125.33, 40.28, 35.02, 34.99, 34.35, 34.03, 31.78, 31.72. HPLC ( $\mathrm{t}=9.35 \mathrm{~min}, 95 \%)$. HRMS (TOF MS ES+) for $\mathrm{C}_{24} \mathrm{H}_{29} \mathrm{O}_{2} \mathrm{~S}_{2}+(\mathrm{MH}+)$ calcd. 413.1609, found 413.1648 .

6-(2-(5,5,8,8-Tetramethyl-5,6,7,8-tetrahydronaphthalen-2-yl)-1,3-dithiolan-2-yl)-2naphthoic acid (15b): To a suspension of the ester 14b $(680 \mathrm{mg}, 1.43 \mathrm{mmol})$ in $75 \%$ aqueous $\mathrm{MeOH}(21 \mathrm{~mL})$ was added $\mathrm{KOH}(0.77 \mathrm{~g})$, and the mixture was stirred at $80^{\circ} \mathrm{C}$ for 3 
$\mathrm{h}$ during which time the compound dissolved. The solution was cooled to room temperature, acidified with $1 \mathrm{~N} \mathrm{HCl}$, and a white solid precipitated out. The solid was filtered, washed with water and allowed to dry to yield a white solid, $621 \mathrm{mg}(94 \%) . \mathrm{mp}=270-272^{\circ} \mathrm{C} .{ }^{1} \mathrm{H}$ NMR (400 MHz, DMSO) $\delta 13.08$ (bs, 1H), 8.54 (s, 1H), 8.29 (s, 1H), 8.04 (d, $J=8.6 \mathrm{~Hz}$, $1 \mathrm{H}), 8.00(\mathrm{~d}, J=8.7 \mathrm{~Hz}, 2 \mathrm{H}), 8.00-7.96(\mathrm{~m}, 1 \mathrm{H}), 7.53(\mathrm{dd}, J=8.7,1.7 \mathrm{~Hz}, 1 \mathrm{H}), 7.47$ (d, $J$ $=1.9 \mathrm{~Hz}, 1 \mathrm{H}), 7.23(\mathrm{~d}, J=8.4 \mathrm{~Hz}, 1 \mathrm{H}), 7.14(\mathrm{dd}, J=8.4,1.8 \mathrm{~Hz}, 1 \mathrm{H}), 3.59-3.47(\mathrm{~m}, 2 \mathrm{H})$, $3.44-3.27(\mathrm{~m}, 2 \mathrm{H}), 1.60(\mathrm{~s}, 4 \mathrm{H}), 1.20(\mathrm{~s}, 6 \mathrm{H}), 1.13(\mathrm{~s}, 6 \mathrm{H}) .{ }^{13} \mathrm{C}$ NMR (101 MHz, DMSO) $\delta$ $167.35,144.88,143.82,143.49,140.23,134.15,131.02,129.84,129.02,128.63,128.45$, $127.76,126.25,125.76,125.41,125.28,124.99,76.31,34.41,34.36,33.90,33.67,31.55$, 31.43. HPLC ( $\mathrm{t}=9.97 \mathrm{~min}, 95 \%)$. HRMS (TOF ESI+) for $\mathrm{C}_{28} \mathrm{H}_{31} \mathrm{O}_{2} \mathrm{~S}_{2}{ }^{+}(\mathrm{M}+\mathrm{H})^{+}$calcd. 463.1765, found 463.1769 .

(4-Iodophenyl)(5,5,8,8-tetramethyl-5,6,7,8-tetrahydronaphthalen-2-yl)methanone (16): Compound $\mathbf{1 6}$ was prepared according to method $\mathrm{C}$ starting from $1.90 \mathrm{~g}$ of the commercially available 1,1,4,4- tetramethyl-1,2,3,4-tetrahydronaphthalene (10 mmol). After work-up, the crude product was purified by flash column chromatography to yield compound $\mathbf{1 6}$ as a yellow oil, $3.57 \mathrm{~g}(85 \%) .{ }^{1} \mathrm{H}$ NMR $\left(400 \mathrm{MHz}, \mathrm{CDCl}_{3}\right) \delta 7.84(\mathrm{~d}, J=8.4 \mathrm{~Hz}, 2 \mathrm{H}), 7.76$ (d, $J$ $=1.8 \mathrm{~Hz}, 1 \mathrm{H}), 7.51(\mathrm{dd}, J=8.2,2.0 \mathrm{~Hz}, 1 \mathrm{H}), 7.52(\mathrm{~d}, J=8.4 \mathrm{~Hz}, 2 \mathrm{H}), 7.40(\mathrm{~d}, J=8.2 \mathrm{~Hz}$, 1H), $1.72(\mathrm{~s}, 4 \mathrm{H}), 1.31$ (s, 6H), 1.29 (s, 6H). ${ }^{13} \mathrm{C}$ NMR (101 MHz, $\left.\mathrm{CDCl}_{3}\right) \delta$ 195.71, 150.44, 145.20, 137.43, 137.31, 134.27, 131.42, 128.72, 127.21, 126.63, 99.67, 34.81, 34.73, 34.69, $34.39,31.74,31.60$. MS (TOF ESI+) for $\mathrm{C}_{21} \mathrm{H}_{24} \mathrm{IO}^{+}(\mathrm{M}+\mathrm{H})^{+}$calcd. 419.09, found 419.09.

\section{(E)-Methyl 3-(4-(5,5,8,8-tetramethyl-5,6,7,8-tetrahydronaphthalene-2-}

carbonyl)phenyl)acrylate (17): Prepared according to the modified procedure reported by Heck et al. ${ }^{(9,10)}$ To a 50-mL round bottomed flask equipped with a magnetic stir bar was added $1.65 \mathrm{~g}$ ( $3.94 \mathrm{mmol})$ of iodide $\mathbf{1 6}$ and methyl acrylate $(1.0 \mathrm{~mL}, 9.86 \mathrm{mmol}) . \mathrm{Pd}(\mathrm{OAc})_{2}$ (9 mg, $0.04 \mathrm{mmol}),(2-\mathrm{Tol})_{3} \mathrm{P}(48 \mathrm{mg}, 0.16 \mathrm{mmol})$ and $\mathrm{Et}_{3} \mathrm{~N}(2.2 \mathrm{~mL}, 15.78 \mathrm{mmol})$ were then simultaneously added and a cooled condenser attached. The solution was heated at $100^{\circ} \mathrm{C}$ for 6 hours. The reaction mixture was allowed to cool to room temperature and 20 $\mathrm{mL}$ EtOAc was added After filtration, the solution was concentrated under reduced pressure and purified by flash column chromatography (cyclohexane-EtOAc 100:0 v/v increasing to $95: 5 \mathrm{v} / \mathrm{v})$ to yield 17 as a yellow solid $(1.22 \mathrm{~g}, 82 \%) . \mathrm{mp}=138-140{ }^{\circ} \mathrm{C} .{ }^{1} \mathrm{H}$ NMR $(400 \mathrm{MHz}$, $\left.\mathrm{CDCl}_{3}\right) \delta 7.82(\mathrm{~d}, J=8.3 \mathrm{~Hz}, 2 \mathrm{H}), 7.79(\mathrm{~d}, J=1.8 \mathrm{~Hz}, 1 \mathrm{H}), 7.75(\mathrm{~d}, J=16.1 \mathrm{~Hz}, 1 \mathrm{H}), 7.63$ $(\mathrm{d}, J=8.3 \mathrm{~Hz}, 2 \mathrm{H}), 7.54(\mathrm{dd}, J=8.2,1.9 \mathrm{~Hz}, 1 \mathrm{H}), 7.41(\mathrm{~d}, J=8.2 \mathrm{~Hz}, 1 \mathrm{H}), 6.55(\mathrm{~d}, J=16.0$ $\mathrm{Hz}, 1 \mathrm{H}), 3.83$ (s, 3H), 1.72 (s, 4H), 1.32 (s, 6H), 1.30 (s, 6H). ${ }^{13} \mathrm{C} \mathrm{NMR}\left(101 \mathrm{MHz}, \mathrm{CDCl}_{3}\right)$ $\delta 195.88,167.16,150.58,145.36,143.72,139.42,137.90,134.59,130.65,128.90,127.90$, 127.44, 126.76, 120.09, 52.01, 34.98, 34.90, 34.85, 34.55, 31.90, 31.77. MS (TOF MS ES+) for $\mathrm{C}_{25} \mathrm{H}_{29} \mathrm{O}_{3}(\mathrm{MH}+)$ calcd. 377.21, found 377.21.

(E)-3-(4-(5,5,8,8-Tetramethyl-5,6,7,8-tetrahydronaphthalene-2-carbonyl)phenyl)acrylic acid (18): Compound $17(0.82 \mathrm{mmol})$ was hydrolyzed according to method B. The resultant oil was purified by flash column chromatography (cyclohexane-EtOAc-HOAc 100:0:0.1 v/v increasing to 80:20:0.1 v/v) to provide compound 18 as a white solid $(278 \mathrm{mg}, 93 \%) . \mathrm{mp}=$ 220-221 ${ }^{\circ} \mathrm{C} .{ }^{1} \mathrm{H}$ NMR $\left(400 \mathrm{MHz}, \mathrm{CDCl}_{3}\right) \delta 7.85(\mathrm{~d}, J=16.8 \mathrm{~Hz}, 1 \mathrm{H}), 7.84(\mathrm{~d}, J=8.0 \mathrm{~Hz}$, $1 \mathrm{H}), 7.80(\mathrm{~d}, J=1.8 \mathrm{~Hz}, 1 \mathrm{H}), 7.66(\mathrm{~d}, J=8.2 \mathrm{~Hz}, 2 \mathrm{H}), 7.54(\mathrm{dd}, J=8.2,1.8 \mathrm{~Hz}, 1 \mathrm{H}), 7.41$ 
$(\mathrm{d}, J=8.2 \mathrm{~Hz}, 1 \mathrm{H}), 6.57(\mathrm{~d}, J=16.0 \mathrm{~Hz}, 1 \mathrm{H}), 1.73(\mathrm{~s}, 4 \mathrm{H}), 1.32(\mathrm{~s}, 6 \mathrm{H}), 1.30(\mathrm{~s}, 6 \mathrm{H}) .{ }^{13} \mathrm{C}$ NMR $\left(101 \mathrm{MHz}, \mathrm{CDCl}_{3}\right) \delta$ 195.94, 171.95, 150.72, 145.91, 145.41, 139.81, 137.49, 134.51, 130.70, 128.95, 128.21, 128.03, 127.48, 126.80, 119.58, 114.86, 34.98, 34.90, 34.88, 34.57, 31.91, 31.77. HPLC ( $\mathrm{t}=10.06 \mathrm{~min}, 80 \%$, (E)-isomer). HRMS (TOF ESI-) for $\mathrm{C}_{24} \mathrm{H}_{25} \mathrm{O}_{3}{ }^{-}$ $(\mathrm{M}-\mathrm{H})^{-}$calcd. 361.1804 found 361.1817 .

Methyl-3-(4-((5,5,8,8-tetramethyl-5,6,7,8-tetrahydronaphthalen-2yl)methyl)phenyl)propanoate (19): Compound 17 (515 mg, $1.36 \mathrm{mmol})$ was treated according to method $\mathrm{F}$. The crude was purified on by column chromatography (cyclohexaneethyl acetate: 100:0 v/v increasing to 90:10 v/v) to provide a colorless oil $(479 \mathrm{mg}, 93 \%) .{ }^{1} \mathrm{H}$ NMR (400 MHz, $\left.\mathrm{CDCl}_{3}\right) \delta 7.19(\mathrm{~d}, J=8.1 \mathrm{~Hz}, 1 \mathrm{H}), 7.15-7.08$ (Aromatic, 5H), 6.90 (dd, $J$ $=8.1,1.9 \mathrm{~Hz}, 1 \mathrm{H}), 3.89(\mathrm{~s}, 2 \mathrm{H}), 3.65(\mathrm{~s}, 3 \mathrm{H}), 2.91(\mathrm{t}, J=7.9 \mathrm{~Hz}, 2 \mathrm{H}), 2.61(\mathrm{t}, J=7.9 \mathrm{~Hz}$, $2 \mathrm{H}), 1.66(\mathrm{~s}, 4 \mathrm{H}), 1.25(\mathrm{~s}, 12 \mathrm{H}) .{ }^{13} \mathrm{C} \mathrm{NMR}\left(101 \mathrm{MHz}, \mathrm{CDCl}_{3}\right) \delta 173.52,144.87,142.56$, 139.40, 138.15, 138.03, 129.17, 128.40, 126.97, 126.69, 126.21, 51.70, 41.41, 35.87, 35.30, $35.25,34.30,34.06,32.02,32.00,30.67$.

\section{3-\{4-[(5,5,8,8-Tetramethyl-5,6,7,8-tetrahydronaphthalen-2-yl)methyl]phenyl $\} 9$} propanoic acid (20): Compound 19 (422 $\mathrm{mg}, 1.16 \mathrm{mmol}$ ) was hydrolyzed according to method B. The crude was purified by flash column chromatography (DCM-MeOH 100:0 v/v increasing to $95: 5 \mathrm{v} / \mathrm{v}$ ) to provide compound $\mathbf{2 0}$ as a white solid (301 $\mathrm{mg}, 77 \%) .{ }^{1} \mathrm{H}$ NMR $\left(400 \mathrm{MHz}, \mathrm{CDCl}_{3}\right) \delta 7.20(\mathrm{~d}, J=8.1 \mathrm{~Hz}, 1 \mathrm{H}), 7.12(5 \mathrm{H}), 6.90(\mathrm{dd}, J=8.1,1.8 \mathrm{~Hz}, 1 \mathrm{H}), 3.89$ $(\mathrm{s}, 2 \mathrm{H}), 2.92(\mathrm{t}, J=7.8 \mathrm{~Hz}, 2 \mathrm{H}), 2.66(\mathrm{t}, J=7.8 \mathrm{~Hz}, 2 \mathrm{H}), 1.66(\mathrm{~s}, 4 \mathrm{H}), 1.25(\mathrm{~s}, 12 \mathrm{H}) . \mathrm{mp}=$ $142-143^{\circ} \mathrm{C}$. HPLC $(\mathrm{t}=9.83 \mathrm{~min}, 95 \%)$. HRMS (TOF ESI + ) for $\mathrm{C}_{24} \mathrm{H}_{31} \mathrm{O}_{2}{ }^{+}(\mathrm{M}+\mathrm{H})^{+}$calcd. 351.2324 , found 351.2321 .

\section{(E)-Methyl-3-(4-(2-(5,5,8,8-tetramethyl-5,6,7,8-tetrahydronaphthalen-2-yl)-1,3-} dioxolan-2-yl)- phenyl)acrylate (21): Compound 17 (650 mg, $1.73 \mathrm{mmol}$ ) was treated according to method $\mathrm{D}$. The crude was puridied by flash column chromatography (cyclohexane-EtOAc 100:0 v/v increasing to 80:20 v/v). Compound 21 was obtained as a white solid, $385 \mathrm{mg}(53 \%) . \mathrm{mp}=155-157^{\circ} \mathrm{C} .{ }^{1} \mathrm{H}$ NMR $\left(400 \mathrm{MHz}, \mathrm{CDCl}_{3}\right) \delta 7.67(\mathrm{~d}, J=$ $16.0 \mathrm{~Hz}, 1 \mathrm{H}), 7.55(\mathrm{~d}, J=8.4 \mathrm{~Hz}, 2 \mathrm{H}), 7.48(\mathrm{~d}, J=8.3 \mathrm{~Hz}, 2 \mathrm{H}), 7.45$ (d, $J=1.9 \mathrm{~Hz}, 1 \mathrm{H})$, $7.23(\mathrm{~d}, J=8.2 \mathrm{~Hz}, 1 \mathrm{H}), 7.17$ (dd, $J=8.2,1.9 \mathrm{~Hz}, 1 \mathrm{H}), 6.42(\mathrm{~d}, J=16.0 \mathrm{~Hz}, 1 \mathrm{H}), 4.12-$ $4.05(\mathrm{~m}, 2 \mathrm{H}), 4.05-3.99(\mathrm{~m}, 2 \mathrm{H}), 1.65(\mathrm{~s}, 4 \mathrm{H}), 1.24(\mathrm{~s}, 6 \mathrm{H}), 1.23(\mathrm{~s}, 6 \mathrm{H}) .{ }^{13} \mathrm{C}$ NMR $(101$ $\left.\mathrm{MHz}, \mathrm{CDCl}_{3}\right) \delta 167.56,144.94,144.92,144.77,144.62,138.51,134.09,128.06,126.86$, $126.60,123.91,123.47,118.03,109.42,77.48,77.16,76.84,65.02,51.84,35.22,35.16$, 34.47, 34.25, 32.00, 31.93. MS (TOF ESI+) for $\mathrm{C}_{27} \mathrm{H}_{33} \mathrm{O}_{4}{ }^{+}(\mathrm{M}+\mathrm{H})^{+}$calcd. 421.24, found 421.24 .

(E)-3-(4-(2-(5,5,8,8-Tetramethyl-5,6,7,8-tetrahydronaphthalen-2-yl)-1,3-dioxolan-2yl)phenyl)- acrylic acid (22): Compound 21 was hydrolyzed according to method B. T The crude was purified by flash column chromatography (DCM-MeOH 100:0 v/v increasing to 95:5 v/v) to provide compound 22 as a white solid, $50 \mathrm{mg}(56 \%) . \mathrm{mp}=241-243^{\circ} \mathrm{C} .{ }^{1} \mathrm{H}$ NMR $\left(400 \mathrm{MHz}, \mathrm{CDCl}_{3}\right) \delta 7.77(\mathrm{~d}, J=15.9 \mathrm{~Hz}, 1 \mathrm{H}), 7.57(\mathrm{~d}, J=8.3 \mathrm{~Hz}, 2 \mathrm{H}), 7.51(\mathrm{~d}, J=$ $8.3 \mathrm{~Hz}, 2 \mathrm{H}), 7.45(\mathrm{~d}, J=1.6 \mathrm{~Hz}, 1 \mathrm{H}), 7.23(\mathrm{~d}, J=8.3 \mathrm{~Hz}, 1 \mathrm{H}), 7.17$ (dd, $J=8.2,1.7 \mathrm{~Hz}$, $1 \mathrm{H}), 6.43(\mathrm{~d}, J=16.0 \mathrm{~Hz}, 1 \mathrm{H}), 4.21-3.93(\mathrm{~m}, 4 \mathrm{H}), 1.65(\mathrm{~s}, 4 \mathrm{H}), 1.25(\mathrm{~s}, 6 \mathrm{H}), 1.23(\mathrm{~s}$, 
6H). ${ }^{13} \mathrm{C}$ NMR (101 MHz, $\left.\mathrm{CDCl}_{3}\right) \delta 172.04,146.81,145.43,144.97,144.81,138.45$, 133.74, 128.37, 126.94, 126.62, 123.92, 123.46, 117.42, 109.40, 65.04, 35.22, 35.16, 34.48, 34.26, 32.01, 31.93. HPLC ( $\mathrm{t}=9.60 \mathrm{~min}, 100 \%)$. HRMS (TOF ESI + ) for $\mathrm{C}_{26} \mathrm{H}_{31} \mathrm{O}_{4}{ }^{+}\left(\mathrm{MH}^{+}\right)$ calcd. 407.2222, found 407.2228.

Methyl 3-\{4-[2-(5,5,8,8-tetramethyl-5,6,7,8-tetrahydronaphthalen-2-yl)-1,3-dioxolan-2yllphenyl method F. Further purification by flash column chromatography (cyclohexanedichloromethane 80:20 v/v increasing to 0:100 v/v) yielded compound 23 as a white solid, $520 \mathrm{mg}(70 \%) . \mathrm{mp}=120-122^{\circ} \mathrm{C} .{ }^{1} \mathrm{H}$ NMR $\left(400 \mathrm{MHz}, \mathrm{CDCl}_{3}\right) \delta 7.38-7.49(\mathrm{~m}, 3 \mathrm{H}), 7.19-$ $7.24(\mathrm{~m}, 3 \mathrm{H}), 7.10-7.19(\mathrm{~m}, 3 \mathrm{H}), 3.93-4.13(\mathrm{~m}, 4 \mathrm{H}), 3.66(\mathrm{~s}, 3 \mathrm{H}), 2.93(\mathrm{t}, J=7.84 \mathrm{~Hz}$, $2 \mathrm{H}), 2.61(\mathrm{t}, J=7.84 \mathrm{~Hz}, 2 \mathrm{H}), 1.65(\mathrm{~s}, 4 \mathrm{H}), 1.24(2 \mathrm{~s}, 12 \mathrm{H}) .{ }^{13} \mathrm{C} \mathrm{NMR}(101 \mathrm{MHz}, \mathrm{CDCl} 3) \delta$ 173.3, 144.5, 144.4, 140.5, 140.2, 138.8, 128.0, 126.4, 126.3, 123.9, 123.5, 109.6, 64.8, 51.6, 35.6, 35.2, 35.1, 34.3, 34.1, 31.9, 31.8, 30.6. MS (ESI+) $[\mathrm{M}+\mathrm{H}]^{+} 423.24$, calc. 423.25 .

\section{3-\{4-[2-(5,5,8,8-Tetramethyl-5,6,7,8-tetrahydronaphthalen-2-yl)-1,3-dioxolan-2-yl]} phenyl\}4 propanoic acid (24): Compound $23(250 \mathrm{mg}, 0.60 \mathrm{mmol})$ was hydrolyzed according to method B. No further purification is needed after work-up. Compound $\mathbf{2 4}$ was obtained as a white solid $(220 \mathrm{mg}, 91 \%) . \mathrm{mp}=219^{\circ}-220^{\circ} \mathrm{C} .{ }^{1} \mathrm{H} \mathrm{NMR}(400 \mathrm{MHz}, \mathrm{CDCl} 3) \delta$ ppm 7.44 (m, $3 \mathrm{H}), 7.19-7.24$ (d, J=8.28 Hz $1 \mathrm{H}), 7.17$ (m, $3 \mathrm{H}), 3.97-4.09$ (m, $4 \mathrm{H}), 2.94$ (t, $J=7.84 \mathrm{~Hz}, 2 \mathrm{H}), 2.66(\mathrm{t}, J=7.78 \mathrm{~Hz}, 2 \mathrm{H}), 1.65(\mathrm{~s}, 4 \mathrm{H}), 1.24(\mathrm{~s}, 6 \mathrm{H}), 1.23(\mathrm{~s}, 6 \mathrm{H}) .{ }^{13} \mathrm{C}$ NMR (101 MHz, CDCl3) $\delta$ ppm 178.53, 144.53, 144.46, 140.58, 139.83, 138.78, 128.00, 126.46, 126.36, 123.88, 123.50, 109.56, 64.80, 35.40, 30.26, 35.14, 35.09, 34.33, 34.12, 31.89, 31.83. HPLC ( $\mathrm{t}=9.13 \mathrm{~min}, 99 \%)$. HRMS (TOF ESI-) for $\mathrm{C}_{26} \mathrm{H}_{31} \mathrm{O}_{4}{ }^{-}(\mathrm{M}-\mathrm{H})^{-}$calcd. 407.2222 found 407.2216.

Methyl-3-[4-(5,5,8,8-tetramethyl-5,6,7,8-tetrahydronaphthalene-2-carbonyl) phenyl] propanoate (25): A mixture of compound 23 ( $265 \mathrm{mg}, 0.63 \mathrm{mmol}, 1 \mathrm{eq}$ ), iodine (160 mg, $0.63 \mathrm{mmol}, 1$ eq.) and $4 \AA$ molecular sieves $(250 \mathrm{mg})$ in acetone $(6 \mathrm{~mL})$ was stirred for 8 hours under reflux according to a modified method of Sun et al. ${ }^{20}$ After work-up and purification by flash column chromatography (cyclohexane-DCM 80:20 v/v increasing to 20:80 v/v, compound 25 was obtained as a colorless oil (150 mg, 63\%). ${ }^{1} \mathrm{H} \mathrm{NMR} \mathrm{(400} \mathrm{MHz,}$ $\mathrm{CDCl} 3) \delta \mathrm{ppm} 7.71-7.80(\mathrm{~m}, 3 \mathrm{H}), 7.53(\mathrm{~d}, J=8.16 \mathrm{~Hz}, 1 \mathrm{H}), 7.39$ (d, J=8.16 Hz, $1 \mathrm{H}), 7.31$ (d, J=7.91 Hz, $2 \mathrm{H}), 3.69$ (s, $3 \mathrm{H}), 3.04$ (t, $J=7.78 \mathrm{~Hz}, 2 \mathrm{H}), 2.69$ (t, $J=7.72 \mathrm{~Hz}, 2 \mathrm{H}), 1.72$ (s, $4 \mathrm{H}), 1.31$ (s, $6 \mathrm{H}), 1.30$ (s, 6H). ${ }^{13} \mathrm{C}$ NMR (101 MHz, CDCl3) $\delta \mathrm{ppm} 196.25,173.01$, 149.95, 145.11, 145.01, 136.17, 134.89, 130.42, 128.71, 128.12, 127.29, 126.45, 51.72, $35.21,34.89,34.81,34.66,34.40,31.76,31.64,30.86$. MS (TOF ESI+) for $\mathrm{C}_{25} \mathrm{H}_{31} \mathrm{O}_{3}{ }^{+}(\mathrm{M}$ $+\mathrm{H})^{+}$calcd. 379.23, found 379.22 .

\section{3-[4-(5,5,8,8-Tetramethyl-5,6,7,8-tetrahydronaphthalene-2-carbonyl)phenyl] propanoic} acid (26): Compound 25 (50 mg, $0.132 \mathrm{mmol}$ ) was hydrolyzed according to method B. No further purification was needed after work-up. Compound $\mathbf{2 5}$ was obtained as a white solid (45 mg, 94\%). mp $=153^{\circ}-155^{\circ} \mathrm{C} .{ }^{1} \mathrm{H}$ NMR $(400 \mathrm{MHz}, \mathrm{CDCl} 3) \delta 7.70-7.83(\mathrm{~m}, 3 \mathrm{H}), 7.53$ (dd, $J=1.82,8.25 \mathrm{~Hz}, 1 \mathrm{H}), 7.39$ (d, $J=8.25 \mathrm{~Hz}, 1 \mathrm{H}), 7.32$ (d, $J=8.16 \mathrm{~Hz}, 2 \mathrm{H}), 3.05$ (t, $J=$ $7.72 \mathrm{~Hz}, 2 \mathrm{H}), 2.75(\mathrm{t}, J=7.72 \mathrm{~Hz}, 2 \mathrm{H}), 1.72(\mathrm{~s}, 6 \mathrm{H}), 1.31(2 \mathrm{~s}, 12 \mathrm{H}) .{ }^{13} \mathrm{C} \mathrm{NMR}(101 \mathrm{MHz}$, 
CDCl3) $\delta$ ppm 196.31, 150.01, 145.03, 144.76, 136.24, 134.84, 130.46, 128.73, 128.12, 127.30, 126.47, 35.01, 34.88, 34.80, 34.66, 34.40, 31.76, 31.64, 30.51. HPLC $(\mathrm{t}=8.96 \mathrm{~min}$, 99\%). HRMS (TOF ESI-) (M-H)- calcd. 363.1960, found 363.1975.

(E)-Methyl-3-(4-(2-(5,5,8,8-tetramethyl-5,6,7,8-tetrahydronaphthalen-2-yl)-1,3dithiolan-2-yl)- phenyl)acrylate (27): Compound $17(347 \mathrm{mg}, 0.92 \mathrm{mmol})$ was treated according to method $\mathrm{E}$. The crude was purified by flash column chromatography (cyclohexane-EtOAc 100:0 v/v increasing to $90: 10 \mathrm{v} / \mathrm{v}$ ) to provide 27 a colorless oil (380 $\mathrm{mg}, 91 \%) .{ }^{1} \mathrm{H}$ NMR $\left(400 \mathrm{MHz}, \mathrm{CDCl}_{3}\right) \delta 7.67(\mathrm{~d}, J=16.2 \mathrm{~Hz}, 1 \mathrm{H}), 7.66(\mathrm{~d}, J=8.4 \mathrm{~Hz}$, 2H), $7.50(\mathrm{~d}, J=2.0 \mathrm{~Hz}, 1 \mathrm{H}), 7.44(\mathrm{~d}, J=8.4 \mathrm{~Hz}, 2 \mathrm{H}), 7.22(\mathrm{dd}, J=8.4,2.1 \mathrm{~Hz}, 1 \mathrm{H}), 7.18$ $(\mathrm{d}, J=8.3 \mathrm{~Hz}, 1 \mathrm{H}), 6.42(\mathrm{~d}, J=16.0 \mathrm{~Hz}, 1 \mathrm{H}), 3.80(\mathrm{~s}, 3 \mathrm{H}), 3.50-3.40(\mathrm{~m}, 2 \mathrm{H}), 3.42-3.32$ $(\mathrm{m}, 2 \mathrm{H}), 1.66(\mathrm{~s}, 4 \mathrm{H}), 1.25$ (s, 6H), 1.21 (s, 6H). ${ }^{13} \mathrm{C} \mathrm{NMR}\left(101 \mathrm{MHz}, \mathrm{CDCl}_{3}\right) \delta$ 167.59, 147.72, 144.48, 144.42, 144.11, 140.44, 133.28, 129.03, 127.73, 126.37, 125.58, 117.95, $51.85,40.37,35.20,35.16,34.51,34.18,31.94,31.88$. MS (TOF ESI+) for $\mathrm{C}_{27} \mathrm{H}_{33} \mathrm{O}_{2} \mathrm{~S}_{2}{ }^{+}$ $(\mathrm{M}+\mathrm{H})^{+}$calcd. 453.1922, found 453.1916 .

(E)-3-(4-(2-(5,5,8,8-Tetramethyl-5,6,7,8-tetrahydronaphthalen-2-yl)-1,3-dithiolan-2yl)phenyl)- acrylic acid (28): Compound 27 (86 $\mathrm{mg}, 0.19 \mathrm{mmol}$ ) was hydrolyzed according to method B. Without any further purification, compound $\mathbf{2 8}$ is obtained as a white solid, 81 $\mathrm{mg}(97 \%) . \mathrm{mp}=234-236^{\circ} \mathrm{C} .{ }^{1} \mathrm{H}$ NMR $\left(400 \mathrm{MHz}, \mathrm{CDCl}_{3}\right) \delta 7.77(\mathrm{~d}, J=15.9 \mathrm{~Hz}, 1 \mathrm{H}), 7.68$ (d, $J=8.4 \mathrm{~Hz}, 2 \mathrm{H}), 7.50(\mathrm{~d}, J=2.0 \mathrm{~Hz}, 1 \mathrm{H}), 7.47$ (d, $J=8.4 \mathrm{~Hz}, 2 \mathrm{H}), 7.22$ (dd, $J=8.4,2.1$ $\mathrm{Hz}, 1 \mathrm{H}), 7.18(\mathrm{~d}, J=8.3 \mathrm{~Hz}, 1 \mathrm{H}), 6.43(\mathrm{~d}, J=16.0 \mathrm{~Hz}, 1 \mathrm{H}), 3.46$ (ddd, $J=12.3,9.4,7.4 \mathrm{~Hz}$, $2 \mathrm{H}), 3.42-3.34(\mathrm{~m}, 2 \mathrm{H}), 1.66(\mathrm{~s}, 4 \mathrm{H}), 1.25(\mathrm{~s}, 6 \mathrm{H}), 1.21(\mathrm{~s}, 6 \mathrm{H}) .{ }^{13} \mathrm{C} \mathrm{NMR}(101 \mathrm{MHz}$, $\left.\mathrm{CDCl}_{3}\right) \delta 171.89,148.29,146.63,144.52,144.16,140.37,132.92,129.11,128.04,126.40$, $126.38,125.57,117.27,40.40,35.20,35.16,34.52,34.19,31.95,31.89$. HPLC $(\mathrm{t}=10.02$ min, 100\%). HRMS (TOF ESI+) for $\mathrm{C}_{26} \mathrm{H}_{31} \mathrm{O}_{2} \mathrm{~S}_{2}{ }^{+}(\mathrm{M}+\mathrm{H})^{+}$calcd. 439.1765, found 439.1765 .

Methyl-3-\{4-[2-(5,5,8,8-tetramethyl-5,6,7,8-tetrahydronaphthalen-2-yl)-1,3-dithiolan-2yllphenyl propanoate (29): Compound 25 (142 $\mathrm{mg}, 0.375 \mathrm{mmol}$ ) was treated according to method E. The crude was purified by flash column chromatography (cyclohexane/EtOAc 95:5 v/v increasing to $75: 25 \mathrm{v} / \mathrm{v}$ ) to provide a colorless oil $(116 \mathrm{mg}, 68 \%) .{ }^{1} \mathrm{H}$ NMR (400 $\left.\mathrm{MHz}, \mathrm{CDCl}_{3}\right) \delta 7.54(\mathrm{~d}, J=8.4 \mathrm{~Hz}, 2 \mathrm{H}), 7.52(\mathrm{~d}, J=2.1 \mathrm{~Hz}, 1 \mathrm{H}), 7.22(\mathrm{dd}, J=8.4,2.2 \mathrm{~Hz}$, $1 \mathrm{H}), 7.16(\mathrm{~d}, J=8.4 \mathrm{~Hz}, 1 \mathrm{H}), 7.11(\mathrm{~d}, J=8.3 \mathrm{~Hz}, 2 \mathrm{H}), 3.67(\mathrm{~s}, 3 \mathrm{H}), 3.48-3.29(\mathrm{~m}, 4 \mathrm{H})$, $2.93(\mathrm{t}, J=7.9 \mathrm{~Hz}, 2 \mathrm{H}), 2.62(\mathrm{t}, J=7.9 \mathrm{~Hz}, 2 \mathrm{H}), 1.65(\mathrm{~s}, 4 \mathrm{H}), 1.24(\mathrm{~s}, 6 \mathrm{H}), 1.21(\mathrm{~s}, 6 \mathrm{H}) .{ }^{13} \mathrm{C}$ NMR (101 MHz, CDCl3) $\delta$ ppm 173.32, 144.05, 143.64, 142.86, 140.91, 139.30, 128.50, 127.66, 126.28, 126.05, 125.54, 51.61, 40.04, 35.49, 35.10, 35.07, 34.33, 33.99, 31.78, 31.74, 30.41. MS (TOF ESI+) for $\mathrm{C}_{27} \mathrm{H}_{35} \mathrm{O}_{2} \mathrm{~S}_{2} \mathrm{O}_{2}{ }^{+}(\mathrm{M}+\mathrm{H})^{+}$calcd. 455.21, found 455.21.

\section{3-\{4-[2-(5,5,8,8-Tetramethyl-5,6,7,8-tetrahydronaphthalen-2-yl)-1,3-dithiolan-2-} yl]phenyl\}propanoic acid (30): Compound $29(102 \mathrm{mg}, 0.224 \mathrm{mmol})$ was hydrolyzed according to method $\mathrm{B}$. Without any further purification, compound $\mathbf{3 0}$ was obtained as a white solid $(80 \mathrm{mg}, 82 \%) . \mathrm{mp}=165-167^{\circ} \mathrm{C} .{ }^{1} \mathrm{H}$ NMR $\left(400 \mathrm{MHz}, \mathrm{CDCl}_{3}\right) \delta 7.55(\mathrm{~d}, J=8.3$ $\mathrm{Hz}, 2 \mathrm{H}), 7.52(\mathrm{~d}, J=2.1 \mathrm{~Hz}, 1 \mathrm{H}), 7.22(\mathrm{dd}, J=8.4,2.2 \mathrm{~Hz}, 1 \mathrm{H}), 7.16(\mathrm{~d}, J=8.4 \mathrm{~Hz}, 1 \mathrm{H})$, $7.12(\mathrm{~d}, J=7.4 \mathrm{~Hz}, 2 \mathrm{H}), 3.49-3.32(\mathrm{~m}, 4 \mathrm{H}), 2.94(\mathrm{t}, J=7.8 \mathrm{~Hz}, 2 \mathrm{H}), 2.67(\mathrm{t}, J=7.8 \mathrm{~Hz}$, 
2H), $1.65(\mathrm{~s}, 4 \mathrm{H}), 1.25(\mathrm{~d}, J=1.7 \mathrm{~Hz}, 6 \mathrm{H}), 1.21(\mathrm{~s}, 6 \mathrm{H}) .{ }^{13} \mathrm{C}$ NMR $(101 \mathrm{MHz}, \mathrm{CDCl} 3) \delta$ ppm 177.50, 144.10, 143.68, 143.04, 140.91, 139.00, 128.58, 127.67, 126.32, 126.08, 125.57, 40.06, 35.15, 35.11, 34.35, 34.02, 31.80, 31.76, 30.11. HPLC ( $\mathrm{t}=9.67 \mathrm{~min}, 96 \%)$. HRMS (TOF ESI-) for $\mathrm{C}_{26} \mathrm{H}_{31} \mathrm{O}_{2} \mathrm{~S}_{2}{ }^{-}(\mathrm{M}-\mathrm{H})^{-}$calcd. 439.1765, found 439.1743.

5,5,8,8-Tetramethyl-5, 6, 7,8-tetrahydro-naphthalene-2-disulfide (31): 5,5,8,8-

Tetramethyl-5, 6, 7,8-tetrahydro-naphthalene-2-disulfide was prepared according to a procedure described by Boiteau et al. ${ }^{21} \mathrm{mp}=83-85^{\circ} \mathrm{C} .{ }^{1} \mathrm{H} \mathrm{NMR}(400 \mathrm{MHz}, \mathrm{CDCl} 3) \delta \mathrm{ppm}$ 7.41 (d, $J=1.88 \mathrm{~Hz}, 2 \mathrm{H}), 7.28$ (dd, $J=8.28,1.88 \mathrm{~Hz}, 2 \mathrm{H}), 7.23$ (d, $J=8.28 \mathrm{~Hz}, 2 \mathrm{H}), 1.65$ (s,

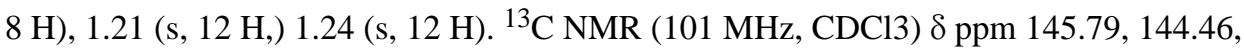
$134.05,127.45,126.89,125.93,34.97,34.95,34.45,34.15,31.75$. MS (TOF ESI+) for $\mathrm{C}_{28} \mathrm{H}_{39} \mathrm{~S}_{2}{ }^{+}(\mathrm{M}+\mathrm{H})^{+}$calcd. 439.24, found 439.25.

Ethyl-3-\{4-[(5,5,8,8-tetramethyl-5,6,7,8-tetrahydronaphthalen-2-yl)sulfanyl] phenyl\} propanoate (32): Compound 32 was prepared according to the method described by Fukuzawa et al. ${ }^{22}$ 5, 5,8,8-Tetramethyl-5, 6, 7,8-tetrahydro-naphthalene-2-disulfide (100 mg, $0.228 \mathrm{mmol}, 0.5$ eq.), $\mathrm{PdCl}_{2}$ (dppf) (17 mg, $0.023 \mathrm{mmol}, 0.05$ eq.), and zinc ( $36 \mathrm{mg}, 0.547$ mmol, 1.2 eq.) were placed in a flask and then a solution of ethyl 3-(4-bromophenyl) propanoate $(115 \mathrm{mg}, 0.456 \mathrm{mmol}, 1$ eq.) in THF ( $3 \mathrm{~mL}$ ) was added. The mixture was refluxed for $24 \mathrm{~h}$ and diluted with $\mathrm{Et}_{2} \mathrm{O}(30 \mathrm{~mL})$ after cooling. The precipitate was removed by filtration and the filtrate was washed with brine and dried over $\mathrm{CaSO}_{4}$. After concentration of the organic layer, the crude was concentrated and grossly purified by column chromatography (cyclohexane-DCM 95:5 v/v increasing to 55:45 v/v). A mixture of 32 and ethyl 3-(4-bromophenyl) propanoate (30\%) was obtained (125 mg). It was used in the next step without any further purification.

Ethyl 3-[4-(5,5,8,8-tetramethyl-5,6,7,8-tetrahydronaphthalene-2-sulfonyl)phenyl] propanoate (33): Compound $32(125 \mathrm{mg}, 0.32 \mathrm{mmol})$ was treated according to method $\mathrm{H}$. After drying over $\mathrm{CaSO}_{4}$ and evaporation, the crude was purified by flash column chromatography (cyclohexane-DCM 80:20 v/v increasing to 0:100 v/v). Compound 33 was obtained as a white solid $(82 \mathrm{mg}, 87 \%)$. $\mathrm{mp}=105-106^{\circ} \mathrm{C} .{ }^{1} \mathrm{H} \mathrm{NMR}\left(400 \mathrm{MHz}, \mathrm{CDCl}_{3}\right) \delta$ ppm $7.88-7.92$ (m, $1 \mathrm{H}), 7.85(\mathrm{~m}, J=8.16 \mathrm{~Hz}, 2 \mathrm{H}), 7.58(\mathrm{dd}, J=8.41,1.51 \mathrm{~Hz}, 1 \mathrm{H}), 7.39$ (d, $J=8.41 \mathrm{~Hz}, 1 \mathrm{H}), 7.33(\mathrm{~m}, J=8.16 \mathrm{~Hz}, 2 \mathrm{H}), 4.10(\mathrm{q}, J=7.11 \mathrm{~Hz}, 2 \mathrm{H}), 2.99$ (t, $J=7.53 \mathrm{~Hz}$, $2 \mathrm{H}), 2.62$ (t, J=7.53 Hz, $2 \mathrm{H}), 1.68(\mathrm{~s}, 4 \mathrm{H}), 1.28(\mathrm{~s}, 6 \mathrm{H}), 1.25$ (s, $6 \mathrm{H}), 1.19$ (t, $J=7.11 \mathrm{~Hz}, 3$ H). $\left.{ }^{13} \mathrm{C} \mathrm{NMR} \mathrm{(101} \mathrm{MHz,} \mathrm{CDCl}_{3}\right) \delta \mathrm{ppm} 172.28,150.80,146.45,146.21,140.05,138.55$, 129.18, 127.81, 127.77, 125.89, 124.49, 60.63, 35.14, 34.69, 34.66, 34.61, 34.55, 31.70, 31.57, 30.68, 14.15. MS (TOF ESI+) for $\mathrm{C}_{50} \mathrm{H}_{65} \mathrm{~S}_{2} \mathrm{O}_{4}{ }^{+}(2 \mathrm{M}+\mathrm{H})^{+}$calcd. 857.40, found 857.40 .

3-[4-(5,5,8,8-Tetramethyl-5,6,7,8-tetrahydronaphthalene-2-sulfonyl)phenyl] propanoic acid (34): 3-Compound $\mathbf{3 3}$ (66 mg, $0.014 \mathrm{mmol}$ ) was hydrolyzed according to method B. With no further purification, compound $\mathbf{3 4}$ is obtained as a white solid $(53 \mathrm{mg}, 85 \%)$. $\mathrm{mp}=$ $211^{\circ} \mathrm{C} .{ }^{1} \mathrm{H}$ NMR $\left(400 \mathrm{MHz}\right.$, METHANOL- $\left.d_{4}\right) \delta \mathrm{ppm} 7.90(\mathrm{~d}, J=2.01 \mathrm{~Hz}, 1 \mathrm{H}), 7.87(\mathrm{~m}$, $J=8.41 \mathrm{~Hz}, 2 \mathrm{H}), 7.65(\mathrm{dd}, J=8.41,2.01 \mathrm{~Hz}, 1 \mathrm{H}), 7.56(\mathrm{~d}, J=8.41 \mathrm{~Hz}, 1 \mathrm{H}), 7.48(\mathrm{~m}, J=8.41$ $\mathrm{Hz}, 2 \mathrm{H}), 3.01$ (t, $J=7.59 \mathrm{~Hz}, 2 \mathrm{H}), 2.65(\mathrm{t}, J=7.59 \mathrm{~Hz}, 2 \mathrm{H}), 1.75(\mathrm{~s}, 4 \mathrm{H}), 1.32(\mathrm{~s}, 6 \mathrm{H}), 1.30$ 
(s, 6H). ${ }^{13} \mathrm{C}$ NMR (101 MHz, METHANOL- $\left.d_{4}\right) \delta$ ppm 176.28, 152.55, 148.81,31. $147.99,87,141.29,140.25,130.73,129.42,128.83,127.00,125.71,36.03,35.87,35.78$, 32.18, 32.02. HPLC ( $\mathrm{t}=8.44 \mathrm{~min}, 99 \%)$. HRMS (TOF ESI-) for $\mathrm{C}_{23} \mathrm{H}_{27} \mathrm{O}_{4} \mathrm{~S}^{-}(\mathrm{M}-\mathrm{H})^{-}$ calcd. 399.1630, found 399.1658 .

6-Iodo-1,1,4,4-tetramethyl-1,2,3,4-tetrahydronaphthalene (35): 6-iodo-1,1,4,4tetramethyl-1,2,3,4-tetrahydronaphthalene was prepared according to Christie et al. ${ }^{23}$

Methyl-2-\{4-[(5,5,8,8-tetramethyl-5,6,7,8-tetrahydronaphthalen-2-yl)sulfanyl] phenyl lacetate (36a): Compound $\mathbf{3 5}$ (305 $\mathrm{mg}, 0.97 \mathrm{mmol}$ ) was treated according to method G. A colorless oil was obtained $(225 \mathrm{mg}, 60 \%)$ as a mixture of compound $\mathbf{3 6 a}$ and its butyl ester derivative (25\%). ${ }^{1} \mathrm{H}$ NMR (400 MHz, $\left.\mathrm{CDCl}_{3}\right) \delta \mathrm{ppm} 7.35$ (d, $\left.J=1.88 \mathrm{~Hz}, 1 \mathrm{H}\right), 7.22-$ 7.25 (m, $3 \mathrm{H}), 7.16-7.21$ (m, $2 \mathrm{H}), 7.09$ (dd, $J=8.28,1.51 \mathrm{~Hz}, 1 \mathrm{H}), 3.69$ (s, $3 \mathrm{H}), 3.59$ (s, 2 $\mathrm{H}), 1.67(\mathrm{~s}, 4 \mathrm{H}), 1.24(\mathrm{~s}, 6 \mathrm{H}), 1.26(\mathrm{~s}, 6 \mathrm{H}) .{ }^{13} \mathrm{C} \mathrm{NMR}\left(101 \mathrm{MHz}, \mathrm{CDCl}_{3}\right) \delta \mathrm{ppm} 171.82$, 146.10, 144.52, 135.78, 132.16, 130.95, 130.25, 129.97, 129.91, 129.10, 127.63, 52.09, 40.70, 34.97, 34.93, 34.37, 34.15, 31.75. MS (TOF ESI+) for $\mathrm{C}_{46} \mathrm{H}_{57} \mathrm{O}_{4} \mathrm{~S}_{2} \mathrm{Na}^{+}(2 \mathrm{M}+\mathrm{Na})^{+}$ calcd. 759.36 , found 759.35 .

Methyl-2-\{3-[(5,5,8,8-tetramethyl-5,6,7,8-tetrahydronaphthalen-2-yl)sulfanyl] phenyl\} acetate (36b): Compound 35 (305 mg, $0.97 \mathrm{mmol}$ ) was treated according to method G. A colorless oil (210 mg, 55\%) was obtained as a mixture of compound $\mathbf{3 6} \mathbf{b}$ and its butyl ester derivative (25\%). ${ }^{1} \mathrm{H}$ NMR $\left(400 \mathrm{MHz}, \mathrm{CDCl}_{3}\right) \delta \mathrm{ppm} 7.34(\mathrm{~d}, J=1.88 \mathrm{~Hz}, 1 \mathrm{H}), 7.23(\mathrm{~m}, 3$ H), 7.14 - 7.18 (m, $1 \mathrm{H}), 7.07$ - 7.14 (m, $2 \mathrm{H}), 3.67$ (s, $3 \mathrm{H}), 3.57$ (s, $2 \mathrm{H}), 1.68$ (s, $4 \mathrm{H})$, 1.24 (s, $6 \mathrm{H}), 1.27$ (s, $6 \mathrm{H}) .{ }^{13} \mathrm{C}$ NMR $(101 \mathrm{MHz}, \mathrm{CDCl} 3) \delta \mathrm{ppm} 171.62,146.11,144.52$, 137.28, 134.83, 130.80, 130.43, 130.18, 129.16, 129.02, 128.42, 127.62, 127.31, 52.05, 40.97, 34.96, 34.93, 34.37, 34.15, 31.75, 31.71. MS (TOF ESI+) for $\mathrm{C}_{46} \mathrm{H}_{57} \mathrm{O}_{4} \mathrm{~S}_{2} \mathrm{Na}^{+}(2 \mathrm{M}$ $+\mathrm{Na})^{+}$calcd. 759.36 , found 759.35 .

Methyl-2-[4-(5,5,8,8-tetramethyl-5,6,7,8-tetrahydronaphthalene-2-sulfonyl) phenyl]acetate (37a): Compound $\mathbf{3 6 a}(105 \mathrm{mg}, 0.27 \mathrm{mmol})$ was treated according to method $\mathrm{H}$. After drying over $\mathrm{CaSO}_{4}$ and evaporation, the crude was purified by flash column chromatography (cyclohexane/dichloromethane): (80/20) to (0/100). An off-white solid was obtained (61 mg, 54\%) as a mixture of compound $\mathbf{3 7 a}$ and its butyl ester derivative $(5 \%) .{ }^{1} \mathrm{H}$ NMR (400 MHz, CDCl3) $\delta$ ppm $7.86-7.93(\mathrm{~m}, 3 \mathrm{H}), 7.58$ (dd, $J=8.41,2.01 \mathrm{~Hz}, 1 \mathrm{H}), 7.40$ (m, $3 \mathrm{H}$ ), 3.69 (s, $3 \mathrm{H}), 3.67$ (s, 2H), 1.68 (s, $4 \mathrm{H}), 1.29$ (s, $6 \mathrm{H}), 1.26$ (s, $6 \mathrm{H}) .{ }^{13} \mathrm{C}$ NMR (101 $\mathrm{MHz}, \mathrm{CDCl} 3) \delta$ ppm 170.99, 150.99, 146.54, 141.05, 139.24, 138.36, 130.29, 130.19, $127.88,126.00,124.61,52.32,40.84,34.74,34.69,34.63,34.58,31.72,31.59$. MS (TOF $\mathrm{ESI}+$ ) for $\mathrm{C}_{46} \mathrm{H}_{57} \mathrm{O}_{8} \mathrm{~S}_{2}{ }^{+}(2 \mathrm{M}+\mathrm{H})^{+}$calcd. 801.34, found 801.34.

Methyl-2-[3-(5,5,8,8-tetramethyl-5,6,7,8-tetrahydronaphthalene-2-sulfonyl) phenyl] acetate (37b): Compound $\mathbf{3 6} \mathbf{b}(90 \mathrm{mg}, 0.23 \mathrm{mmol}$ ) was treated according to method $\mathrm{H}$. After drying over $\mathrm{CaSO}_{4}$ and evaporation, the crude was purified by flash column chromatography (cyclohexane/dichloromethane): (80/20) to (0/100). Compound 37b was obtained as a thick oil $(50 \mathrm{mg}, 51 \%) .{ }^{1} \mathrm{H}$ NMR $(400 \mathrm{MHz}, \mathrm{CDCl} 3) \delta \mathrm{ppm} 7.90$ (d, $J=2.01$ $\mathrm{Hz}, 1 \mathrm{H}), 7.88$ (s, $1 \mathrm{H}), 7.83$ (dt, $J=7.00,1.65 \mathrm{~Hz}, 1 \mathrm{H}), 7.59$ (dd, $J=8.41,1.88 \mathrm{~Hz}, 1 \mathrm{H}), 7.43$ -7.52 (m, 2 H), 7.40 (d, J=8.41 Hz, 1 H), 3.69 (s, 5 H), 1.68 (s, 4 H), 1.29 (s, 6 H), 1.26 (s, 
$6 \mathrm{H}) .{ }^{13} \mathrm{C}$ NMR $\left(101 \mathrm{MHz}, \mathrm{CDCl}_{3}\right) \delta \mathrm{ppm} 170.98,150.99,146.54,142.39,138.30,135.38$, 133.94, 129.43, 128.34, 127.84, 126.44, 126.01, 124.55, 52.25, 40.70, 34.72, 34.67, 34.61, 34.55, 31.70, 31.57. MS (TOF ESI+) for $\mathrm{C}_{46} \mathrm{H}_{57} \mathrm{O}_{8} \mathrm{~S}_{2}{ }^{+}(2 \mathrm{M}+\mathrm{H})^{+}$calcd. 801.34, found 801.34 .

2-\{4-[(5,5,8,8-Tetramethyl-5,6,7,8-tetrahydronaphthalen-2-yl)sulfanyl] phenyl\}acetic acid (38a): Compound 36a $(50 \mathrm{mg}, 0.136 \mathrm{mmol})$ was hydrolyzed according to method B. With no further purification, compound 38a was obtained as a white solid (43 $\mathrm{mg}, 99 \%)$. mp $=87^{\circ} \mathrm{C} .{ }^{1} \mathrm{H}$ NMR $\left(400 \mathrm{MHz}, \mathrm{CDCl}_{3}\right) \delta$ ppm $7.33-7.37$ (m, $\left.1 \mathrm{H}\right), 7.15-7.25(\mathrm{~m}, 5 \mathrm{H}), 7.07$ - 7.12 (m, $1 \mathrm{H}), 3.60$ (s, $2 \mathrm{H}), 1.67$ (s, $4 \mathrm{H}), 1.27$ (s, $6 \mathrm{H}), 1.24(\mathrm{~s}, 6 \mathrm{H}) .{ }^{13} \mathrm{C}$ NMR $(101 \mathrm{MHz}$, $\left.\mathrm{CDCl}_{3}\right) \delta \mathrm{ppm} 177.38,146.17,144.67,136.36,131.30,130.71,130.50,130.03,129.97$, 129.80, 129.34, 127.70, 40.52, 34.99, 34.96, 34.41, 34.19, 31.79. HPLC ( $\mathrm{t}=9.50 \mathrm{~min}, 95 \%)$. HRMS (TOF ESI-) for $\left[\left(\mathrm{C}_{22} \mathrm{H}_{26} \mathrm{O}_{2} \mathrm{~S}\right)_{2}-1\right]^{-}(2 \mathrm{M}-\mathrm{H})^{-}$calcd. 707.3229, found 707.3204.

2-\{3-[(5,5,8,8-Tetramethyl-5,6,7,8-tetrahydronaphthalen-2-yl)sulfanyl $]$ phenyl $\}$ acetic acid (38b): Compound 36b (50 $\mathrm{mg}, 0.136 \mathrm{mmol}$ ) was hydrolyzed according to method B. With no further purification, compound $\mathbf{3 8 b}$ was obtained as a colorless oil (43 mg, 99\%). ${ }^{1} \mathrm{H}$ NMR (400 MHz, $\left.\mathrm{CDCl}_{3}\right) \delta \mathrm{ppm} 7.34(\mathrm{~d}, J=1.88 \mathrm{~Hz}, 1 \mathrm{H}), 7.19-7.24(\mathrm{~m}, 3 \mathrm{H})$, $7.14-7.19$ (m, $1 \mathrm{H}), 7.07-7.13$ (m, $2 \mathrm{H}), 3.58$ (s, $2 \mathrm{H}), 1.67$ (s, $4 \mathrm{H}), 1.27$ (s, $6 \mathrm{H}), 1.22$ (s, 6H). ${ }^{13} \mathrm{C}$ NMR $\left(101 \mathrm{MHz}, \mathrm{CDCl}_{3}\right) \delta \mathrm{ppm} 177.31,146.20,144.63,137.55,134.15,130.68$, 130.50, 130.30, 129.25, 129.14, 128.58, 127.68, 127.41, 34.99, 34.98, 34.40, 34.19, 31.79, 31.75. HPLC ( $\mathrm{t}=9.45 \mathrm{~min}, 95 \%)$. HRMS (TOF ESI-) for $\mathrm{C}_{22} \mathrm{H}_{25} \mathrm{O}_{2} \mathrm{~S}^{-}(2 \mathrm{M}-\mathrm{H})^{-}$calcd. 707.3229, found 707.3286.

\section{2-[4-(5,5,8,8-Tetramethyl-5,6,7,8-tetrahydronaphthalene-2-sulfonyl)phenyl]acetic acid} (39a): Compound 37a (45 mg, $0.112 \mathrm{mmol}$ ) was hydrolyzed according to method B. With no further purification, compound 39a was obtained as white solid $(31 \mathrm{mg}, 72 \%) . \mathrm{mp}=$ $214^{\circ} \mathrm{C} .{ }^{1} \mathrm{H}$ NMR $\left(400 \mathrm{MHz}, \mathrm{CDCl}_{3}\right) \delta \mathrm{ppm} 7.87-7.93(\mathrm{~m}, 3 \mathrm{H}), 7.58(\mathrm{dd}, J=8.41,2.01 \mathrm{~Hz}$, $1 \mathrm{H}), 7.40$ (m, $3 \mathrm{H}), 3.70$ (s, $2 \mathrm{H}), 1.68(\mathrm{~s}, 4 \mathrm{H}), 1.29$ (s, $6 \mathrm{H}), 1.25$ (s, $6 \mathrm{H}) .{ }^{13} \mathrm{C}$ NMR (101 $\left.\mathrm{MHz}, \mathrm{CDCl}_{3}\right) \delta \mathrm{ppm} 175.32,151.05,146.56,141.30,138.42,138.23,130.25,127.92$, $127.88,126.01,124.60,34.74,34.68,34.62,34.55,31.71,31.59$. HPLC ( $\mathrm{t}=8.32 \mathrm{~min}, 99 \%)$. HRMS (TOF ESI-) for [ $\left.\left(\mathrm{C}_{22} \mathrm{H}_{26} \mathrm{O}_{4} \mathrm{~S}\right)_{2}-1\right]-(\mathrm{M}-\mathrm{H})-$ calcd. 771.3025, found 771.3063.

\section{2-[3-(5,5,8,8-Tetramethyl-5,6,7,8-tetrahydronaphthalene-2-sulfonyl)phenyl]acetic acid} (39b): Compound 38b (45 mg, $0.112 \mathrm{mmol}$ ) was hydrolyzed according to method B. With no further purification, compound $\mathbf{3 9 b}$ was obtained as white solid (41 mg, 95\%). $\mathrm{mp}=$ $75^{\circ} \mathrm{C} .{ }^{1} \mathrm{H}$ NMR $\left(400 \mathrm{MHz}, \mathrm{CDCl}_{3}\right) \delta \mathrm{ppm} 7.89$ (s, $\left.2 \mathrm{H}\right), 7.84$ (d, J=6.27 Hz, $\left.1 \mathrm{H}\right), 7.56-$ $7.63(\mathrm{~m}, 1 \mathrm{H}), 7.43-7.52(\mathrm{~m}, 2 \mathrm{H}), 7.39$ (d, J=8.41 Hz, $1 \mathrm{H}), 3.72(\mathrm{~s}, 2 \mathrm{H}), 1.67(\mathrm{~s}, 4 \mathrm{H})$, 1.27 (s, $6 \mathrm{H}), 1.25$ (s, $6 \mathrm{H}) .{ }^{13} \mathrm{C}$ NMR $\left(101 \mathrm{MHz}, \mathrm{CDCl}_{3}\right) \delta \mathrm{ppm} 175.74,151.05,146.59$, $142.48,138.22,134.75,134.01,129.49,128.46,127.86,126.62,126.04,124.54,34.73$, $34.66,34.61,34.56,31.68,31.57$. HPLC $(\mathrm{t}=8.27 \mathrm{~min}$, 99\%). HRMS (TOF ESI-) for $\mathrm{C}_{22} \mathrm{H}_{25} \mathrm{O}_{4} \mathrm{~S}^{-}(\mathrm{M}-\mathrm{H})-$ calcd. 385.1474, found 385.1494. 


\section{Crystallography}

Compounds $\mathbf{7}$ and $\mathbf{8}$ yielded crystals of suitable quality for X-ray diffraction by slow evaporation of ethyl acetate/heptane solutions. These crystals were used to confirm the structures using X-ray data collected at $90 \mathrm{~K}$, with $\mathrm{Cu} \mathrm{Ka}$ radiation $(\lambda=1.54178 \AA$ ) on a Bruker Kappa Apex-II diffractometer. Crystals of $\mathbf{8}$ are triclinic, space group P-1 with $\mathrm{Z}=2$, $\mathrm{R}=0.036$, CCDC 896010. Crystals of 7 are monoclinic, space group $\mathrm{P} 2{ }_{1} / \mathrm{c}$ with $\mathrm{Z}=4$, $\mathrm{R}=0.065$, CCDC 896011. There is a conformational disorder of the six-membered ring carrying the four methyl groups. The CIFs have been deposited at the Cambridge Crystallographic Data Centre and can be obtained free of charge via www.ccdc.cam.ac.uk/ data_request/cif.

\section{CYP26A1 and CYP26B1 inhibition assays}

CYP26A1 and CYP26B1 were expressed in Sf9 cells and used as microsomal fractions supplemented with rat $\mathrm{P} 450$ reductase expressed in Escherichia coli as described previously. ${ }^{11,33}$ Incubations were performed with 5 pmol of P450 (CYP26A1 or CYP26B1) and 10 pmol of $\mathrm{P} 450$ reductase. The purified rat reductase was added to CYP26A1 or CYP26B1 microsomes, and allowed to incorporate into the membrane for $10 \mathrm{~min}$ at room temperature. The final volume of each incubation sample was then brought to $1 \mathrm{ml}$ by adding $100 \mathrm{mM}$ potassium phosphate (KPi) buffer, $\mathrm{pH}$ 7.4, 9-cis-RA, and, when appropriate, inhibitor or solvent. Compounds were dissolved in methanol or dimethyl sulfoxide, and final solvent amounts in the incubations were kept at $1 \%$. The samples were preincubated for 5 min at $37^{\circ} \mathrm{C}$ before the reaction was initiated with NADPH (final concentration $1 \mathrm{mM}$ ). Incubation times were 1 minute and 5 minutes for CYP26A1 and CYP26B1 incubations respectively.

To determine whether the RA isomer 9-cis-RA is a substrate of CYP26B1, 9-cis-RA was incubated with CYP26B1. The formation of 9-cis-4-OH-RA by CYP26B1 was measured by HPLC as described previously for CYP26A1. ${ }^{25}$ Product formation was linear from 1 minute to 8 minutes. The $\mathrm{K}_{\mathrm{m}}$ and $\mathrm{k}_{\text {cat }}$ of 9-cis-RA hydroxylation by CYP26B1 was determined by incubating 8 different concentrations of 9-cis-RA between $50 \mathrm{nM}$ and $1000 \mathrm{nM}$ with CYP26B1. Five minutes after reactions were initiated with NADPH the reactions were quenched with $5 \mathrm{ml}$ of ethyl acetate, acitretin was added as an internal standard, samples extracted, evaporated to dryness, reconstituted in methanol and analyzed by HPLC as described previously. ${ }^{25}$ A standard curve of 9-cis-4-OH-RA was used to quantify product formation by analysis of the peak area of the primary metabolite on an HPLC. The Michaelis-Menten equation was fit to the data using GraphPad Prism (GraphPad Software Inc., San Diego, CA), and the $\mathrm{K}_{\mathrm{m}}$ and $\mathrm{V}_{\max }$ values were obtained from this fit. 9-cis-RA was then used as the substrate for subsequent assays of inhibitor potency at $100 \mathrm{nM}$ concentration.

Twenty novel compounds, $\mathbf{1}, \mathbf{3}$ and two RAR ligands $\mathbf{1 5 b}$ and $\mathbf{1 3 a}$ were tested as inhibitors of CYP26A1 and CYP26B1. The formation of 9-cis-4-OH-RA metabolite was monitored and the percent activity remaining in the presence of the inhibitor in comparison to the solvent only control was quantified. For $\mathrm{IC}_{50}$ determination, $6-8$ concentrations of the inhibitor spanning below and above the predicted $\mathrm{IC}_{50}$ were tested, and each concentration 
was analyzed in triplicate. The $\mathrm{IC}_{50}$ values were determined by nonlinear regression using GraphPad Prism, according to eq. 1:

$$
100 \% \cdot \frac{V_{i}}{V}=\left(\frac{V_{i}}{V}\right)_{\min } \cdot 100 \%+\frac{\left(\left(V_{i} / V\right)_{\max }-\left(V_{i} / V\right)_{\min } \cdot 100 \%\right)}{\left(1+10^{\left(I-\log I C_{50}\right)}\right)}
$$

in which $100 \% *\left(\mathrm{~V}_{\mathrm{i}} / \mathrm{V}\right)$ is the percentage of activity remaining at a given inhibitor (I) concentration, $\left(\mathrm{V}_{\mathrm{i}} / \mathrm{V}\right)_{\max } * 100 \%$ is the fitted maximum percentage activity remaining, and $\left(\mathrm{V}_{\mathrm{i}} / \mathrm{V}\right)_{\min }{ }^{*} 100 \%$ is the minimum percentage activity remaining. For compounds with $\mathrm{IC}_{50}$ values less than $100 \mathrm{nM}$, all fits were corrected for inhibitor depletion, and the $K_{d}$ was determined using the Morrison equation as described previously ${ }^{(15)}$ according to eq. 2 :

$$
[E I]=\frac{[E]+[I]+K_{d}-\sqrt{\left([E]+[I]+K_{d}\right)^{2}-4[E][I]}}{2}
$$

in which $\mathrm{K}_{\mathrm{d}}$ is the affinity constant of the inhibitor, [I] is the concentration of inhibitor, [E] is the concentration of enzyme, and [EI] is the concentration of the enzyme-inhibitor complex.

\section{RAR activation and induction of RAR $\gamma$ and CYP26A1 in HepG2 cells}

The HepG2 cells were obtained and cultured in a humidified incubator at $37{ }^{\circ} \mathrm{C}$ under a $5 \%$ atmosphere of carbon dioxide using DMEM (Dulbecco's Modified Eagle Medium) containing 4.5g/L D-glucose, L-glutamine, and $110 \mathrm{mg} / \mathrm{L}$ Sodium Pyruvate supplemented with $10 \%$ FBS and $1 \%$ penicillin. (Life Technologies, Grand Island, NY) For all treatments, cells were plated into six well plates in $2 \mathrm{~mL}$ media and allowed to adhere for 24 hours prior to treatments.

To test whether any of the candidate compounds activate RAR, HepG2 cells were treated for 24 hours in $2 \mathrm{~mL}$ media with $0.1 \%$ DMSO (vehicle control), and the test compounds at a concentration of $1 \mu \mathrm{M}$ in $0.1 \%$ DMSO. To determine whether the test compounds inhibited a $t$ RA metabolism in the HepG2 cells and hence potentiated the RAR activation (CYP26A1 and RAR $\gamma$ induction) cells were treated with either vehicle control (0.1\% DMSO+0.01\% ethanol), 10,100 or $1000 \mathrm{nM}$ a $t \mathrm{RA}$ or $1 \mu \mathrm{M}$ of each test compound together with $100 \mathrm{nM}$ a $t$ RA. Each treatment was performed as triplicate. At the completion of each treatment, the media was collected for measurement of atRA concentration and cells were harvested for mRNA extraction. To each well, $300 \mu \mathrm{L}$ of TRI reagent (Invitrogen, Grand Island, NY) was added and mRNA extracted according to manufacturers recommendations. mRNA concentration was quantified using the Nanodrop 2000c Spectrophotometer. (Thermofisher Sci., Waltham, MA) and cDNA generated from $1 \mu \mathrm{g}$ mRNA using Taqman ${ }^{\circledR}$ Gene expression reagents (Applied Biosystems, Carlsbad, CA). RT-PCR was used to quantify CYP26A1 mRNA (StepOnePlus ${ }^{\mathrm{TM}}$, Applied Biosystems, Carlsbad, CA) as previously described. ${ }^{30}$ TaqMan real-time gene expression master mix and PCR primers and fluorescent probes were obtained from Applied Biosystems (Foster City, CA). Probes were labeled with the 5'-reporter dye 5-carboxyfluorescein and a nonfluorescent black hole quencher on the $3^{\prime}$ end. Primer and probe pairs used included: CYP26A1 (Hs00175627_m1, FAM), GAPDH (Hs99999905_m1, VIC). GAPDH was used as the housekeeping gene and all assays were done as multiplexes. All triplicate samples were analyzed in singlet. Changes in target 
mRNA were measured using relative quantification (fold-difference) and the $\Delta \Delta \mathrm{C}_{\mathrm{T}}$ method. ${ }^{30}$ The effect of the inhibitors on atRA metabolism in HepG2 cells was determined using LC-MS/MS as previously described, ${ }^{29}$ using an AB Sciex QTRAP 4500 mass spectrometer coupled with an Agilent 1290 Infinity UHPLC and Agilent Zorbax C18 column $(3.5 \mu \mathrm{m}, 2.1 \mathrm{~mm} \times 100 \mathrm{~mm})$ using negative ion electrospray detection

\section{Inhibition of CYP3A4, CYP2C19, CYP2D6 and CYP2B6}

The inhibition of drug metabolizing P450 enzymes by the lead compounds was tested using midazolam (CYP3A4), (S)-mephenytoin (CYP2C19), dextromethorphan (CYP2D6) and bupropion (CYP2B6) as selective substrates as previously described. ${ }^{34,35}$ Briefly, human liver microsomes were incubated with the substrate and inhibitor in $100 \mathrm{mM}$ potassium phosphate buffer. All incubations were initiated with NADPH and quenched with ice cold acetonitrile at the end of the incubation period. Product formation was measured by LCMS/MS using an AB Sciex 4500 mass spectrometer (AB Sciex, Foster City, CA) coupled to a Shimadzu UFLC XR DGU-20A5 (Shimadzu Scientific Instruments, Columbia, MD).

\section{Supplementary Material}

Refer to Web version on PubMed Central for supplementary material.

\section{Acknowledgments}

This work was supported by NIH grants P30NS055022 (PD, CMK), RRIA award from the Michael J. Fox Foundation for Parkinson's Research (PD), R41AG046987 (FAD, NG), UL1 TR00042301 (PD, NI), R01GM081569 (NI, BB) and R01GM111772 (NI, ST, LP, WH), CNPq Scholar - Brasil (VGS).

\section{ABBREVIATIONS}

CYP Cytochrome P450

HRMS High resolution mass spectrometry

RA retinoic acid

RAR retinoic acid receptor

TTN 1,1,4,4-tetramethyl-1,2,3,4-tetrahydronaphthalene

\section{References}

1. Gudas LJ. Emerging Roles for Retinoids in Regeneration and Differentiation in Normal and Disease States. Biochim Biophys Acta. 2012; 1821:213-221. [PubMed: 21855651]

2. Napoli JL. Physiological Insights into All-Trans-Retinoic Acid Biosynthesis. Biochim Biophys Acta. 2012; 1821:152-167. [PubMed: 21621639]

3. Blomhoff R, Blomhoff HK. Overview of Retinoid Metabolism and Function. J Neurobiol. 2006; 66:606-630. [PubMed: 16688755]

4. Hogarth CA, Griswold MD. Retinoic Acid Regulation of Male Meiosis. Curr Opin Endocrinol Diabetes Obes. 2013; 20:217-223. [PubMed: 23511242]

5. Maden M. Retinoic Acid in the Development, Regeneration and Maintenance of the Nervous System. Nat Rev Neurosci. 2007; 8:755-765. [PubMed: 17882253] 
6. Ross AC. Vitamin A and Retinoic Acid in T Cell-Related Immunity. Am J Clin Nutr. 2012; 96:1166S- 72S. [PubMed: 23053562]

7. Nelson CH, Buttrick BR, Isoherranen N. Therapeutic Potential of the Inhibition of the Retinoic Acid Hydroxylases CYP26A1 and CYP26B1 by Xenobiotics. Curr Top Med Chem. 2013; 13:1402-1428. [PubMed: 23688132]

8. Thatcher JE, Isoherranen N. The Role of CYP26 Enzymes in Retinoic Acid Clearance. Expert Opin Drug Metab Toxicol. 2009; 5:875-886. [PubMed: 19519282]

9. Ross AC, Zolfaghari R. Cytochrome P450s in the Regulation of Cellular Retinoic Acid Metabolism. Annu Rev Nutr. 2011; 31:65-87. [PubMed: 21529158]

10. Thatcher JE, Zelter A, Isoherranen N. The Relative Importance of CYP26A1 in Hepatic Clearance of All-Trans Retinoic Acid. Biochem Pharmacol. 2010; 80:903-912. [PubMed: 20513361]

11. Topletz AR, Thatcher JE, Zelter A, Lutz JD, Tay S, Nelson WL, Isoherranen N. Comparison of the Function and Expression of CYP26A1 and CYP26B1, the Two Retinoic Acid Hydroxylases. Biochem Pharmacol. 2012; 83:149-163. [PubMed: 22020119]

12. Njar VC, Gediya L, Purushottamachar P, Chopra P, Vasaitis TS, Khandelwal A, Mehta J, Huynh C, Belosay A, Patel J. Retinoic Acid Metabolism Blocking Agents (RAMBAs) for Treatment of Cancer and Dermatological Diseases. Bioorg Med Chem. 2006; 14:4323-4340. [PubMed: 16530416]

13. Stoppie P, Borgers M, Borghgraef P, Dillen L, Goossens J, Sanz G, Szel H, Van Hove C, Van Nyen G, Nobels G, Vanden Bossche H, Venet M, Willemsens G, Van Wauwe J. R115866 Inhibits AllTrans-Retinoic Acid Metabolism and Exerts Retinoidal Effects in Rodents. J Pharmacol Exp Ther. 2000; 293:304-312. [PubMed: 10734183]

14. Hogarth CA, Evans E, Onken J, Kent T, Mitchell D, Petkovich M, Griswold MD. CYP26 Enzymes Are Necessary Within the Postnatal Seminiferous Epithelium for Normal Murine Spermatogenesis. Biol Reprod. 2015; 93:19. [PubMed: 26040672]

15. Chenery A, Burrows K, Antignano F, Underhill TM, Petkovich M, Zaph C. The Retinoic AcidMetabolizing Enzyme Cyp26b1 Regulates CD4 T Cell Differentiation and Function. PLoS One. 2013; 8:e72308. [PubMed: 23991089]

16. Boehm MF, Zhang L, Badea BA, White SK, Mais DE, Berger E, Suto CM, Goldman ME, Heyman RA. Synthesis and Structure-Activity Relationships of Novel Retinoid X Receptor-Selective Retinoids. J Med Chem. 1994; 37:2930-2941. [PubMed: 8071941]

17. Dawson MI, Jong L, Hobbs PD, Cameron JF, Chao WR, Pfahl M, Lee MO, Shroot B. Conformational Effects on Retinoid Receptor Selectivity. 2. Effects of Retinoid Bridging Group on Retinoid X Receptor Activity and Selectivity. J Med Chem. 1995; 38:3368- 3383. [PubMed: 7650690]

18. Patel BA, Ziegler CB, Cortese NA, Plevyak JE, Zebovitz TC, Terpko M, Heck RF. PalladiumCatalyzed Vinylic Substitution Reactions with Carboxylic Acid Derivatives. J Org Chem. 1977; 42:3903-3907.

19. Heck RF, Nolley JP. Palladium-Catalyzed Vinylic Hydrogen Substitution Reactions with Aryl, Benzyl, and Styryl Halides. J Org Chem. 1972; 37:2320-2322.

20. Sun J, Dong Y, Cao L, Wang X, Wang S, Hu Y. Highly Efficient Chemoselective Deprotection of O,O-Acetals and O,O-Ketals Catalyzed by Molecular Iodine in Acetone. J Org Chem. 2004; 69:8932-8934. [PubMed: 15575776]

21. Boiteau, J.; Rivier, M.; Feraille, GA.; Jomard, A. Nouveaux Composes Inhibiteurs Selectifs Du cyp26a1 Utiles Dans Des Compositions Cosmétiques et Pharmaceutiques. WO2014016507 A1. Jan 30. 2014

22. Fukuzawa S, Tanihara D, Kikuchi S. Palladium-Catalyzed Coupling Reaction of Diaryl Dichalcogenide with Aryl Bromide Leading to the Synthesis of Unsymmetrical Aryl Chalcogenide. Synlett. 2006; 2006:2145-2147.

23. Christie VB, Barnard JH, Batsanov AS, Bridgens CE, Cartmell EB, Collings JC, Maltman DJ, Redfern CP, Marder TB, Przyborski S, Whiting A. Synthesis and Evaluation of Synthetic Retinoid Derivatives as Inducers of Stem Cell Differentiation. Org Biomol Chem. 2008; 6:3497-3507. [PubMed: 19082150] 
24. Millois C, Diaz P. Solution-Phase Synthesis of Diaryl Selenides Using Polymer-Supported Borohydride. Org Lett. 2000; 2:1705-1708. [PubMed: 10880206]

25. Thatcher JE, Buttrick B, Shaffer SA, Shimshoni JA, Goodlett DR, Nelson WL, Isoherranen N. Substrate Specificity and Ligand Interactions of CYP26A1, the Human Liver Retinoic Acid Hydroxylase. Mol Pharmacol. 2011; 80:228-239. [PubMed: 21521770]

26. Gendimenico GJ, Stim TB, Corbo M, Janssen B, Mezick JA. A Pleiotropic Response Is Induced in F9 Embryonal Carcinoma Cells and Rhino Mouse Skin by All-Trans-Retinoic Acid, a RAR Agonist but Not by SR11237, a RXR-Selective Agonist. J Invest Dermatol. 1994; 102:676-680. [PubMed: 8176247]

27. Le Q, Dawson MI, Soprano DR, Soprano KJ. Modulation of Retinoic Acid Receptor Function Alters the Growth Inhibitory Response of Oral SCC Cells to Retinoids. Oncogene. 2000; 19:14571465. [PubMed: 10723137]

28. Holmes WF, Dawson MI, Robert Soprano D, Soprano KJ. Induction of Apoptosis in Ovarian Carcinoma Cells by AHPN/CD437 Is Mediated by Retinoic Acid Receptors. J Cell Physiol. 2000; 185:61-67. [PubMed: 10942519]

29. Topletz AR, Tripathy S, Foti RS, Shimshoni JA, Nelson WL, Isoherranen N. Induction of CYP26A1 by Metabolites of Retinoic Acid: Evidence That CYP26A1 Is an Important Enzyme in the Elimination of Active Retinoids. Mol Pharmacol. 2015; 87:430-441. [PubMed: 25492813]

30. Tay S, Dickmann L, Dixit V, Isoherranen N. A Comparison of the Roles of Peroxisome Proliferator-Activated Receptor and Retinoic Acid Receptor on CYP26 Regulation. Mol Pharmacol. 2010; 77:218-227. [PubMed: 19884280]

31. Gomaa MS, Bridgens CE, Veal GJ, Redfern CP, Brancale A, Armstrong JL, Simons C. Synthesis and Biological Evaluation of 3-(1H-Imidazol- and Triazol-1-Yl)-2,2- Dimethyl-3-[4(naphthalen-2-Ylamino)phenyl]propyl Derivatives as Small Molecule Inhibitors of Retinoic Acid 4-Hydroxylase (CYP26). J Med Chem. 2011; 54:6803-6811. [PubMed: 21838328]

32. Patel JB, Mehta J, Belosay A, Sabnis G, Khandelwal A, Brodie AM, Soprano DR, Njar VC. Novel Retinoic Acid Metabolism Blocking Agents Have Potent Inhibitory Activities on Human Breast Cancer Cells and Tumour Growth. Br J Cancer. 2007; 96:1204-1215. [PubMed: 17387344]

33. Lutz JD, Dixit V, Yeung CK, Dickmann LJ, Zelter A, Thatcher JE, Nelson WL, Isoherranen N. Expression and Functional Characterization of Cytochrome P450 26A1, a Retinoic Acid Hydroxylase. Biochem Pharmacol. 2009; 77:258-268. [PubMed: 18992717]

34. Shirasaka Y, Sager JE, Lutz JD, Davis C, Isoherranen N. Inhibition of CYP2C19 and CYP3A4 by Omeprazole Metabolites and Their Contribution to Drug-Drug Interactionss. Drug Metab Dispos. 2013; 41:1414-1424. [PubMed: 23620487]

35. Sager JE, Lutz JD, Foti RS, Davis C, Kunze KL, Isoherranen N. Fluoxetine- and NorfluoxetineMediated Complex Drug-Drug Interactions: In Vitro to In Vivo Correlation of Effects on CYP2D6, CYP2C19, and CYP3A4. Clin Pharmacol Ther. 2014; 95:653-662. [PubMed: 24569517] 


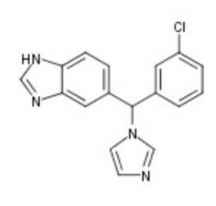

1

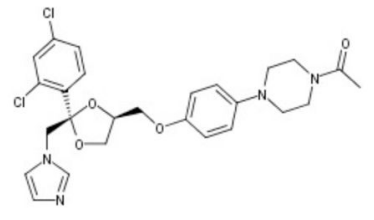

2

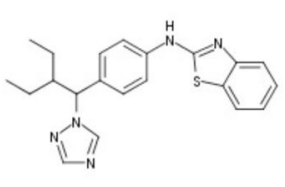

3

Figure 1.

Chemical structures of previously identified CYP26 inhibitors, 1 (liarozole), 2 (ketoconazole), and 3 (talarozole also called R115866 ${ }^{13}$ ). 

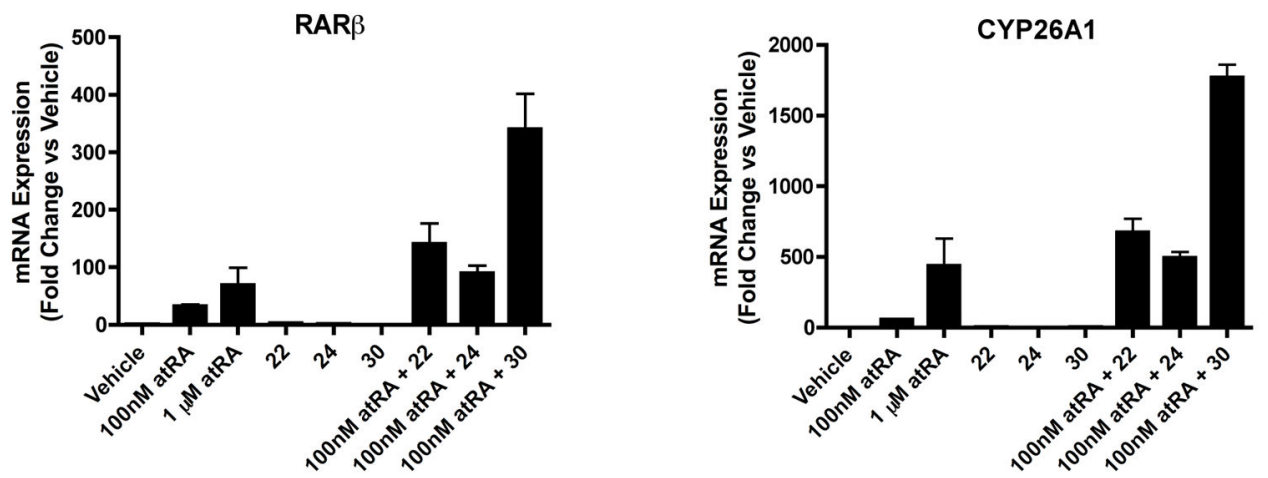

Figure 2.

Induction of RAR $\beta$ and CYP26A1 mRNA in HepG2 cells as measured by rt-PCR. HepG2 cells were treated with $100 \mathrm{nM}$ or $1 \mu \mathrm{M}$ atRA or with $1 \mu \mathrm{M}$ compound $\mathbf{2 2 , 2 4}$ or $\mathbf{3 0}$ alone or in combination with $100 \mathrm{nM}$ atRA. 


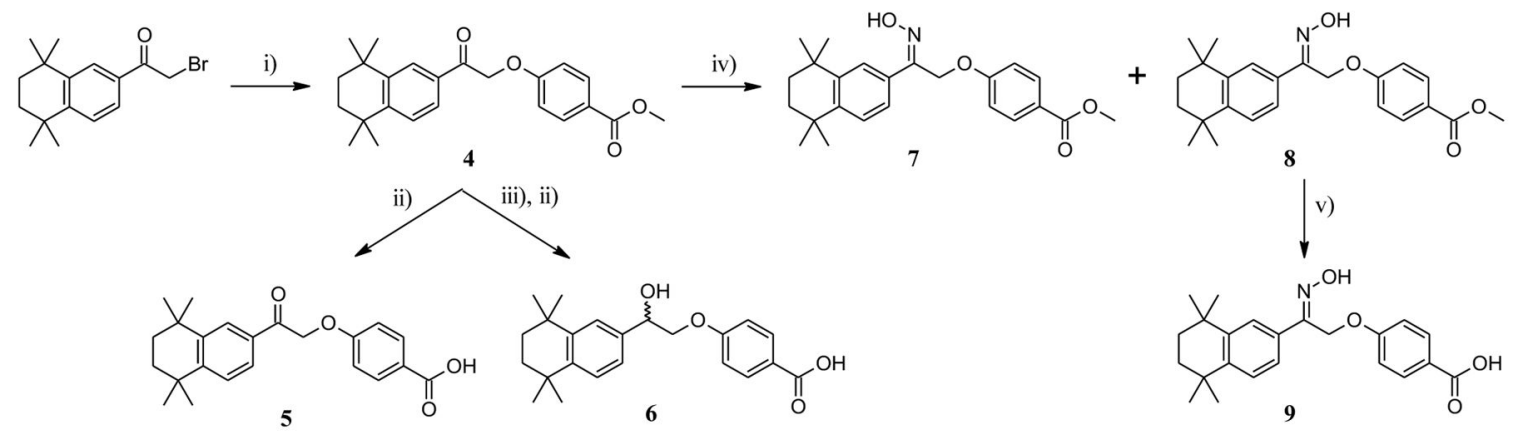

Scheme 1a.

${ }^{a}$ Reagents and conditions: (i) Methyl-4-hydroxybenzoate, $\mathrm{K}_{2} \mathrm{CO}_{3} / \mathrm{MEK}, \mu \mathrm{W}, 100^{\circ} \mathrm{C}, 2 \times 20$ min; (ii) $\mathrm{NaOH}$, THF. EtOH, $\mathrm{H}_{2} \mathrm{O}, 80^{\circ} \mathrm{C}, 12$ h; (iii) $\mathrm{NaBH} 4$, THF, r.t., 1 h; (iv) $\mathrm{H}_{2} \mathrm{NOH} . \mathrm{HCl} /$ $\mathrm{MeOH}$, pyridine, reflux, $6 \mathrm{~h}$; (v) $\mathrm{K}_{2} \mathrm{CO}_{3}(2 \mathrm{M}) / \mathrm{MeOH}$, reflux, $80^{\circ} \mathrm{C}$. 

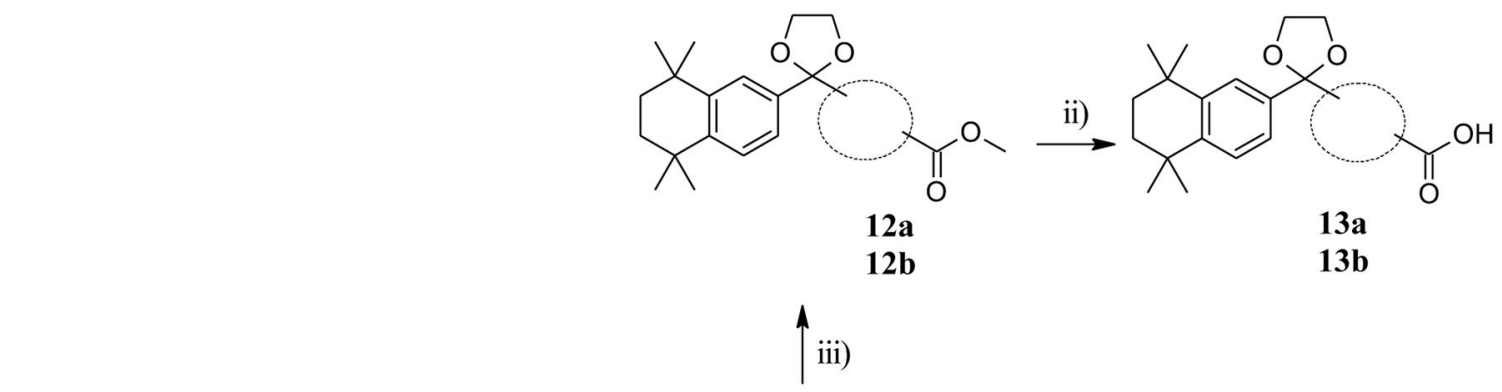

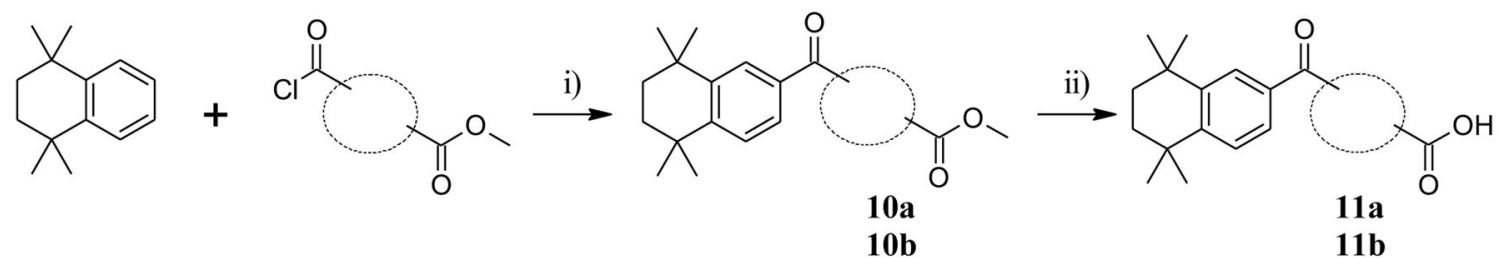<smiles>Cc1ccc(C)cc1</smiles>

a

or<smiles>[c-]1ccc2ccccc2c1</smiles><smiles>CCC1(C2(c3ccc4c(c3)C(C)(C)CCC4(C)C)CCCS2)CCCC(C(=O)OC)CC1</smiles>

$\stackrel{\text { ii) }}{\longrightarrow}$<smiles>CC1(C)CCC(C)(C)c2cc(C3(C4(C)CCCC(C(=O)O)CC4)SCCS3)ccc21</smiles>

$14 b$

$15 \mathrm{a}$

$15 b$

Scheme $2^{\mathrm{a}}$

${ }^{a}$ Reagents and conditions: (i) $\mathrm{AlCl}_{3}, \mathrm{CH}_{2} \mathrm{Cl}_{2}$, r.t., overnight; (ii) $\mathrm{K}_{2} \mathrm{CO}_{3}(2 \mathrm{M}) / \mathrm{MeOH}$, reflux, $80^{\circ} \mathrm{C}$; ; (iii) $\left(\mathrm{CH}_{2} \mathrm{OH}\right)_{2}$, pTsOH, toluene, reflux, overnight; (iv) $\left(\mathrm{CH}_{2} \mathrm{SH}\right)_{2}, \mathrm{BF}_{3} . \mathrm{Et}_{2} \mathrm{O}$,

$\mathrm{CH}_{2} \mathrm{Cl}_{2}$, r.t., $0.5-1 \mathrm{~h}$. 


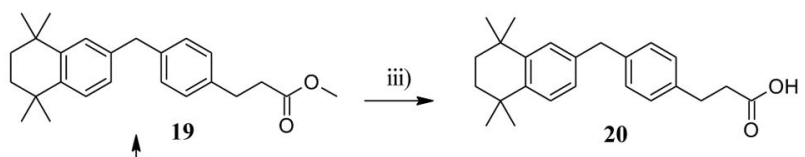

iv)

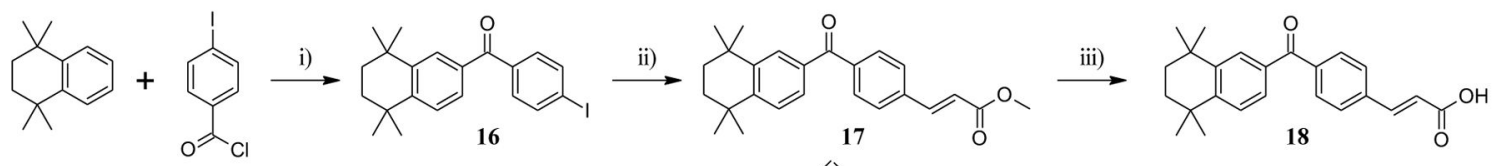<smiles>CCCC</smiles>
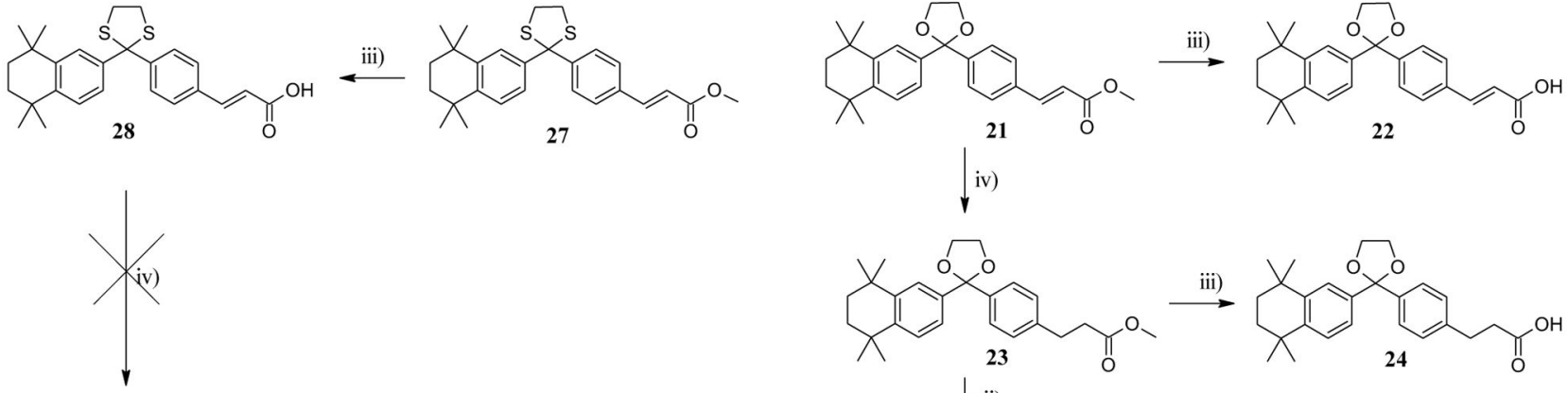

iv)

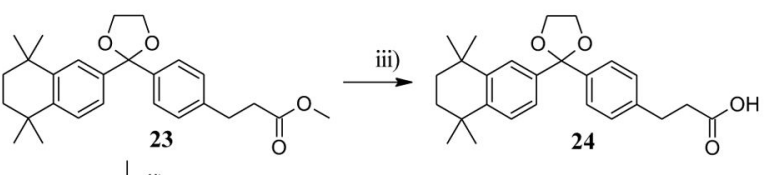

vii)
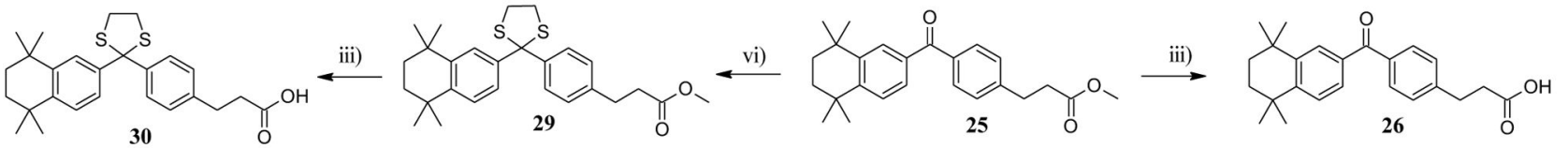

Scheme $3^{\text {a }}$

${ }^{a}$ Reagents and conditions: (i) $\mathrm{AlCl}_{3}, \mathrm{CH}_{2} \mathrm{Cl}_{2}$, r.t., overnight; (ii) methyl acrylate, $\mathrm{Pd}(\mathrm{OAc})_{2}$, $\mathrm{NEt}_{3}, \mathrm{DMF}, 100^{\circ} \mathrm{C}, 6 \mathrm{~h}$; (iii) $\mathrm{LiOH}$ aq. $1 \mathrm{~N}$, THF, reflux, 3 h or r.t., overnight; (iv) $\mathrm{H}_{2}, \mathrm{Pd} / \mathrm{C}$, EtOH/EtOAc 20 psi, 7-12 h; (v) $\left(\mathrm{CH}_{2} \mathrm{OH}\right)_{2}, \mathrm{pTsOH}$, toluene, reflux, overnight; (vi) $\left(\mathrm{CH}_{2} \mathrm{SH}\right)_{2}, \mathrm{BF}_{3} \cdot \mathrm{Et}_{2} \mathrm{O}, \mathrm{CH}_{2} \mathrm{Cl}_{2}$, r.t., $0.5-1 \mathrm{~h}$; (vii) $\mathrm{I}_{2}$, acetone, $4 \AA$ MS, reflux, $16 \mathrm{~h}$. 

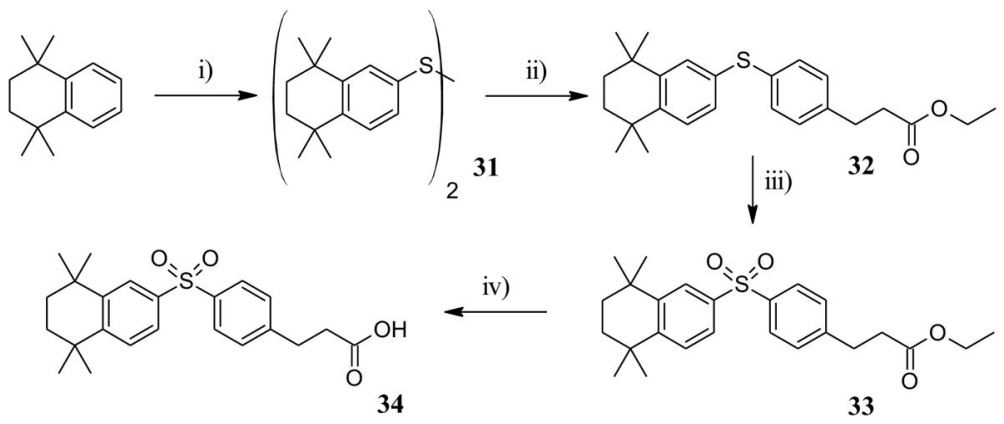

Scheme $4^{\mathrm{a}}$

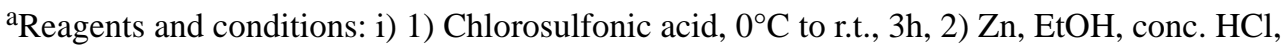
reflux 45 min, r.t. overnight; ii) ethyl 3-(4-bromophenyl)propanoate, $\mathrm{PdCl}_{2}(\mathrm{dppf}), \mathrm{Zn}$, THF, reflux, 24h; iii) oxone, $\mathrm{H}_{2} \mathrm{O}, \mathrm{MeOH}, 0^{\circ} \mathrm{C}$ to r.t., $12 \mathrm{~h}$; iv) $\mathrm{LiOH} 1 \mathrm{~N}$, THF, $\mathrm{H}_{2} \mathrm{O}$, r.t. 12 h. 


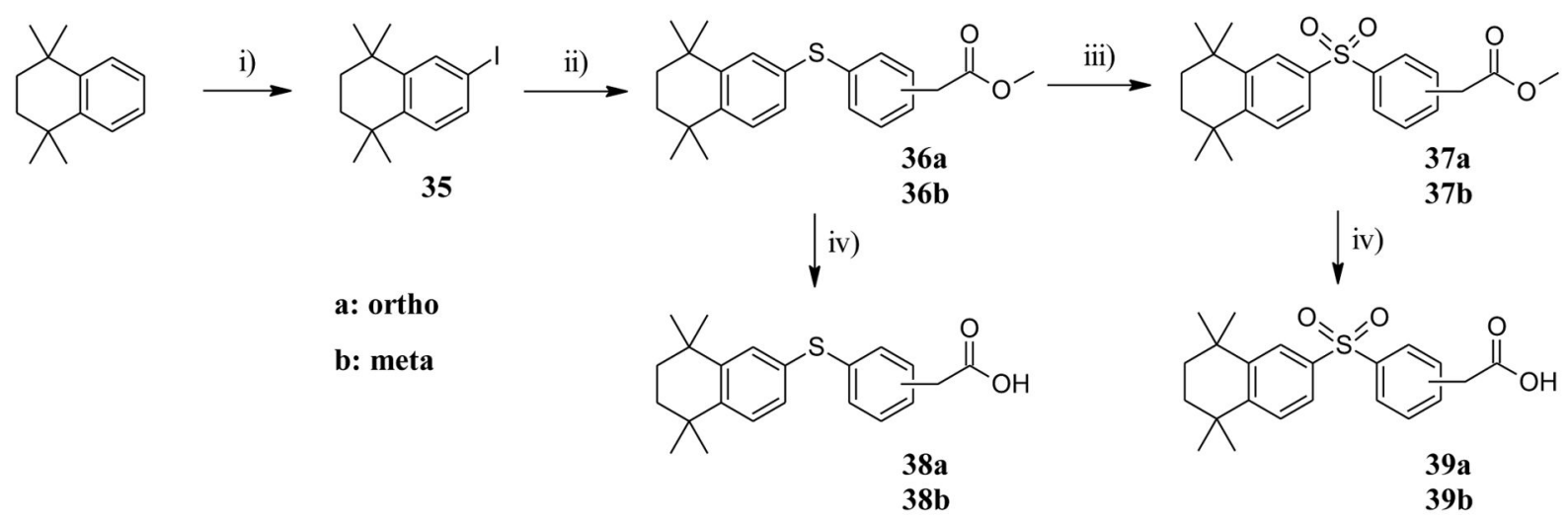

Scheme $5^{\text {a }}$

${ }^{a}$ Reagents and conditions: i) $\mathrm{I}_{2}, \mathrm{H}_{2} \mathrm{SO}_{4}, \mathrm{HIO}_{4}, \mathrm{AcOH}, \mathrm{H}_{2} \mathrm{O}, 70^{\circ} \mathrm{C}$ ii) 3- or 4mercaptophenylacetic acid methyl ester, borohydride, polymer supported, (bpy) ${ }_{2} \mathrm{NiBr}_{2}$, dioxane, $\mathrm{ButOH}, 130-145^{\circ} \mathrm{C}, 3 \mathrm{~h}$ to $5 \mathrm{~h}$; iii) oxone, $\mathrm{H}_{2} \mathrm{O}, \mathrm{MeOH}, 0^{\circ} \mathrm{C}$ to r.t., $12 \mathrm{~h}$; iv) $\mathrm{LiOH}$ $1 \mathrm{~N}, \mathrm{THF}, \mathrm{H}_{2} \mathrm{O}$, r.t. $12 \mathrm{~h}$. 


\section{Table 1}

$\mathrm{IC}_{50}$ values and $95 \%$ confidence intervals of the $\mathrm{IC}_{50}$ for the RAMBAs and synthetic retinoids against CYP26A1 and CYP26B1 for compounds 1, 3, 40, and the naphthyl analogues 11b, $\mathbf{1 3 b}$ and $\mathbf{1 5 b}$.
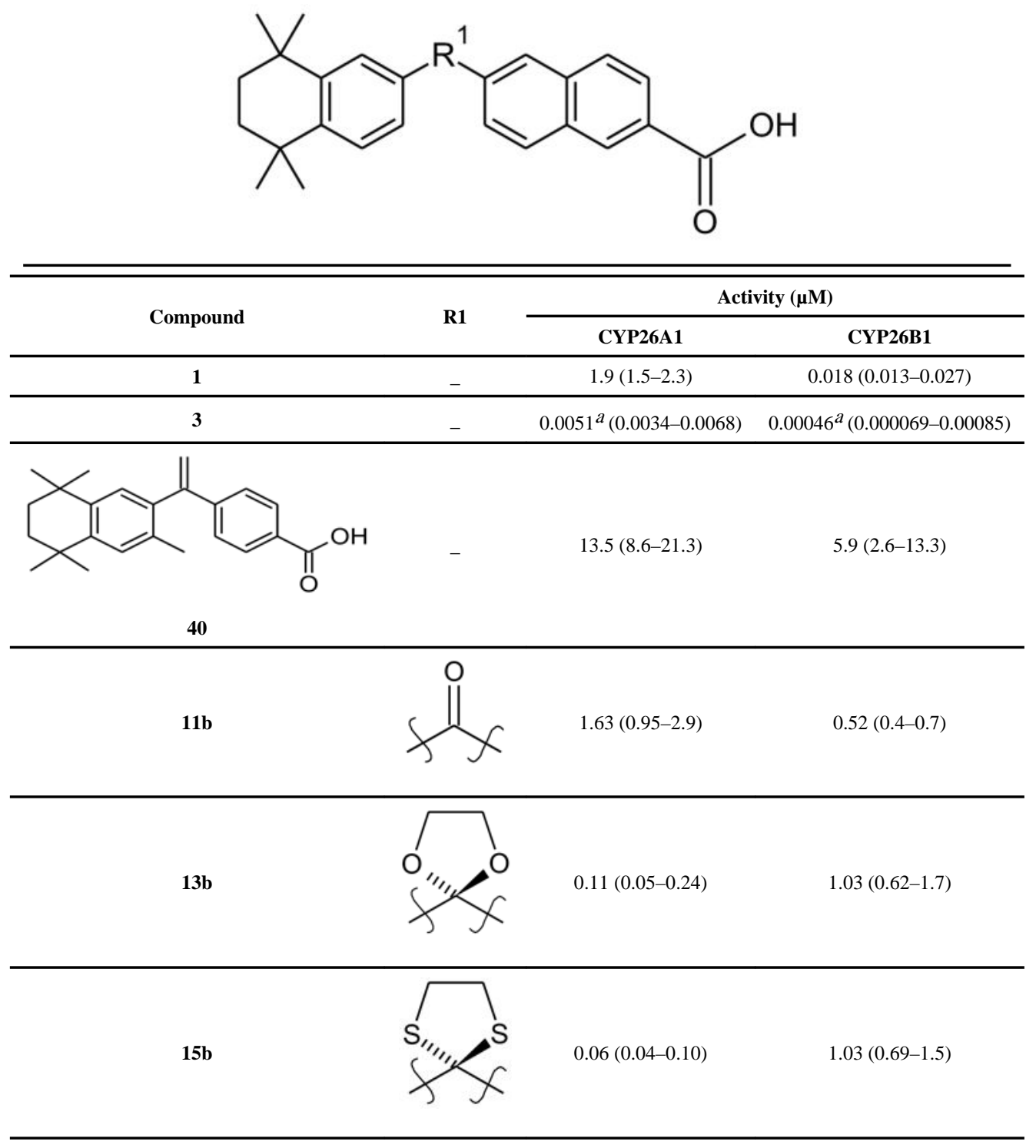

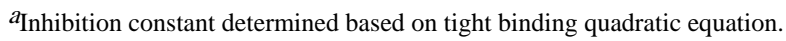




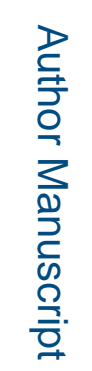

ᄅำ

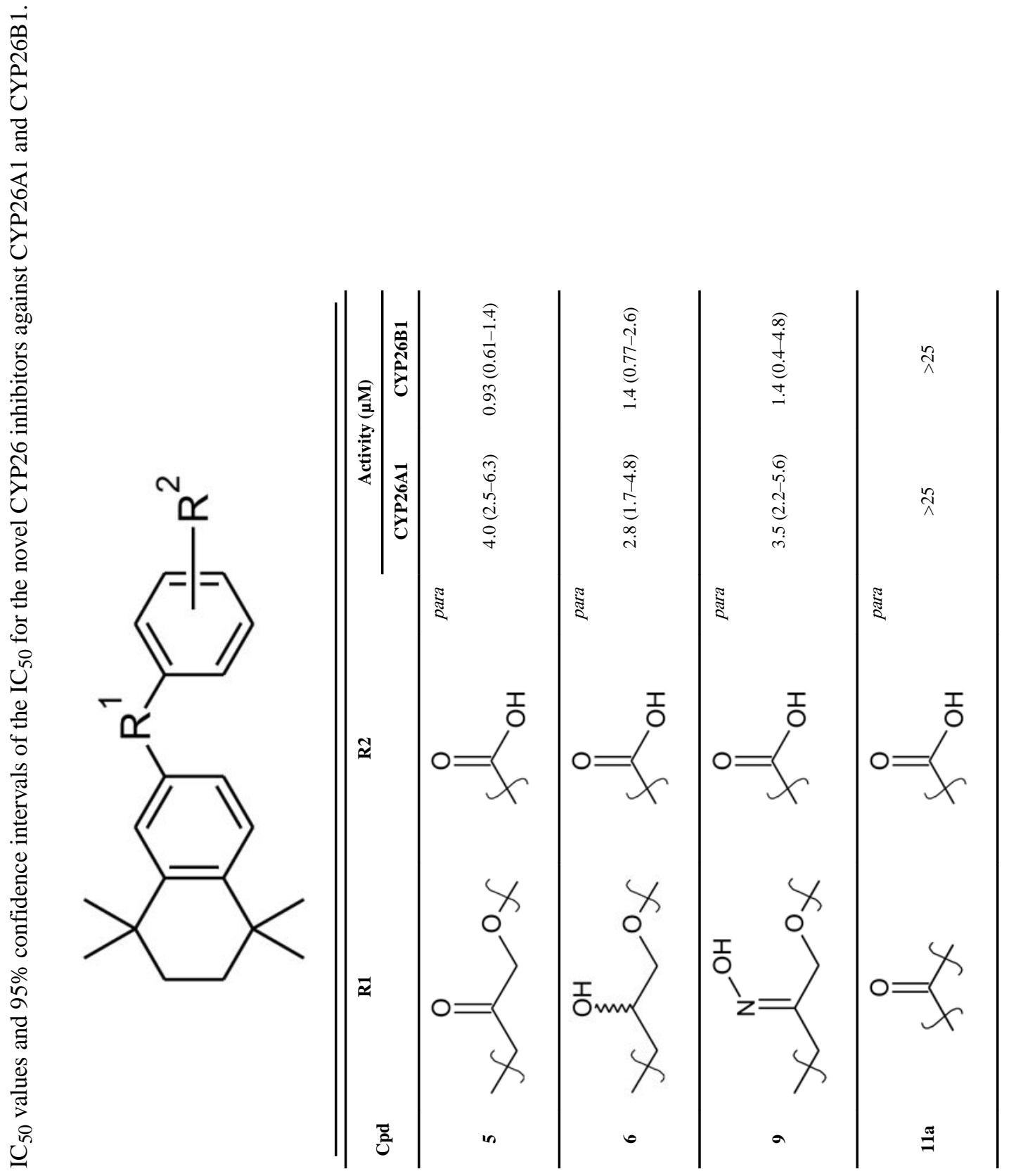

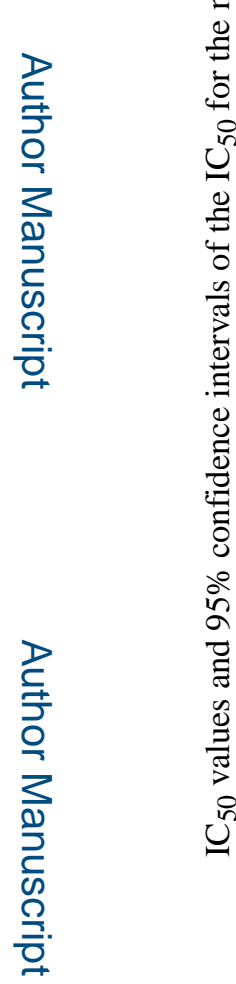

J Med Chem. Author manuscript; available in PMC 2017 March 24. 
Diaz et al.

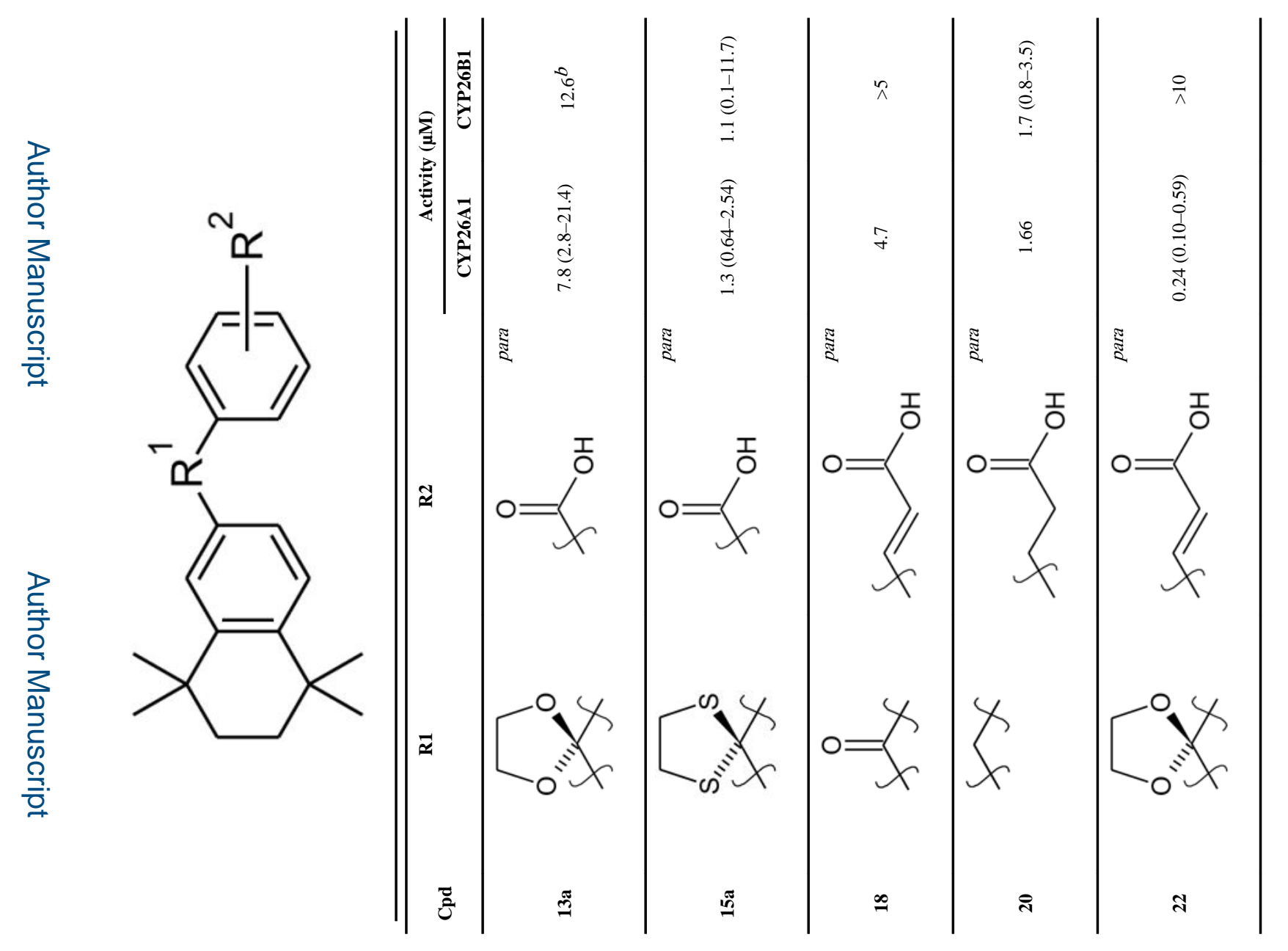

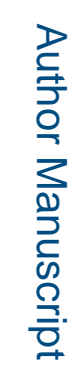

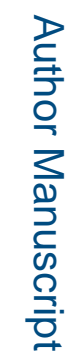


Diaz et al.

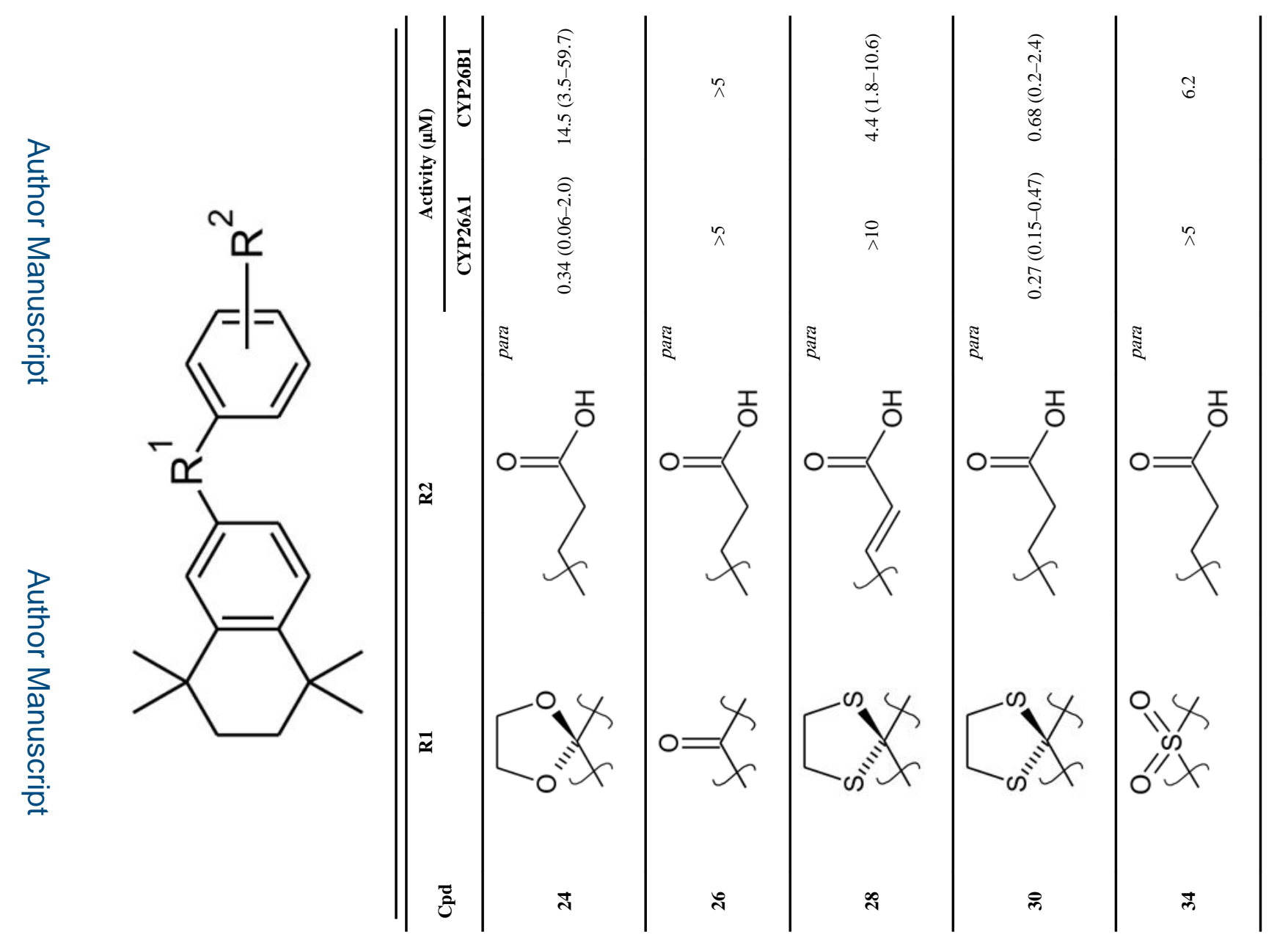

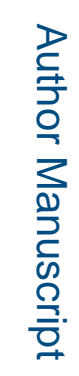

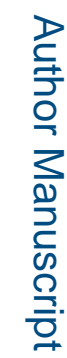


Diaz et al.

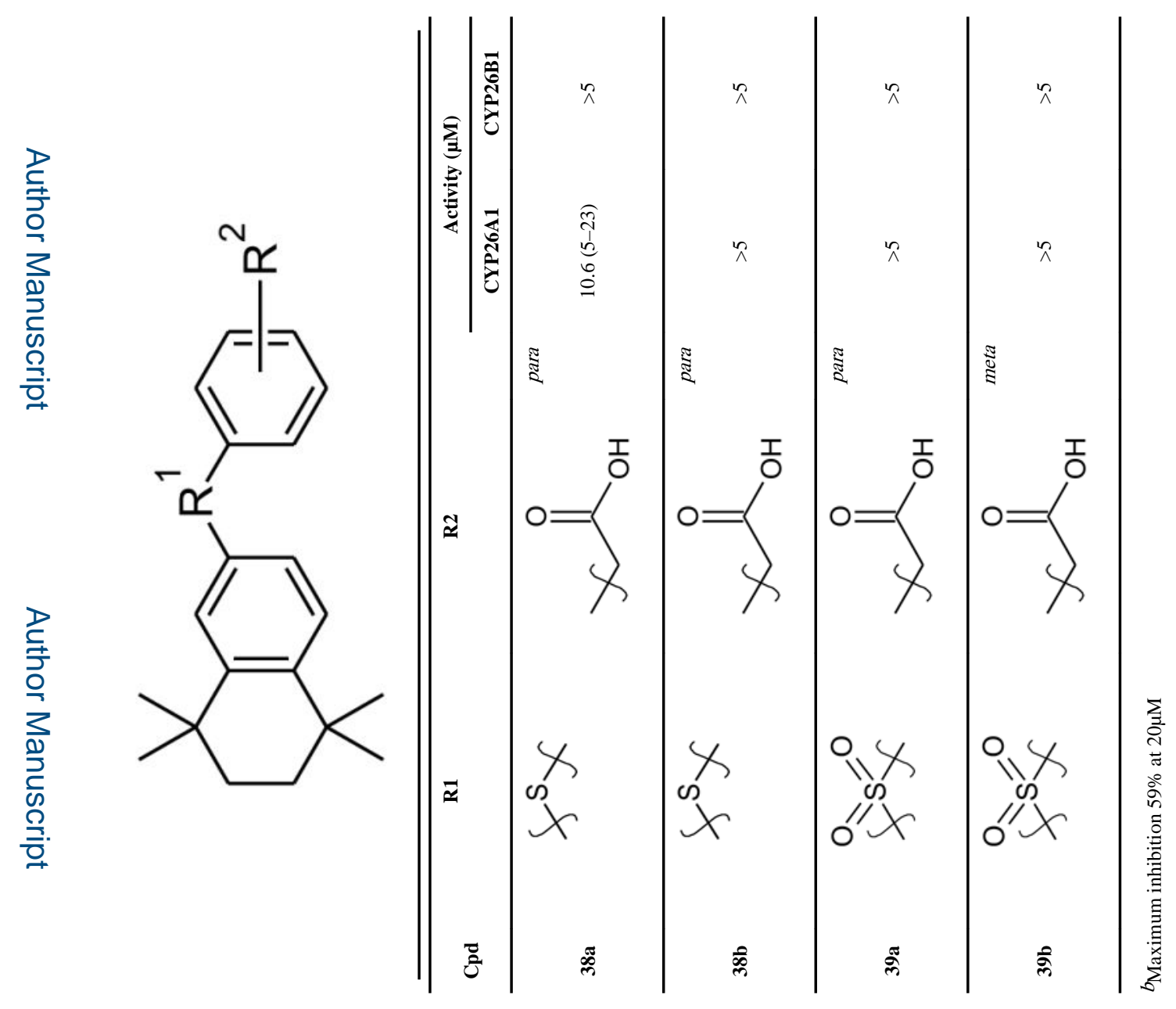

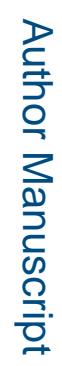

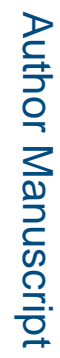

Page 40 
Table 3

\begin{tabular}{|c|c|}
\hline Treatments & at $\mathrm{RA}$ in cell media (nM) \\
\hline Vehicle & $0.49 \pm 0.33$ \\
\hline $100 \mathrm{nM}$ atRA & $13.2 \pm 0.14$ \\
\hline $1 \mu \mathrm{M}$ atRA & $214 \pm 13.6$ \\
\hline $1 \mu \mathrm{M} 22$ & $1.09 \pm 0.52$ \\
\hline $1 \mu \mathrm{M} 24$ & $0.27 \pm 0.09$ \\
\hline $100 \mathrm{nM}$ atRA + 1 $\mu \mathrm{M} 22$ & $45.5 \pm 2.8^{*}$ \\
\hline $100 \mathrm{nM}$ a $t \mathrm{RA}+1 \mu \mathrm{M} 24$ & $25.6 \pm 3.4^{*}$ \\
\hline $100 \mathrm{nM}$ atRA $+1 \mu \mathrm{M} 30$ & $113 \pm 9^{*}$ \\
\hline
\end{tabular}

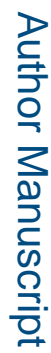

*significantly different from the $100 \mathrm{nM}$ RA treatment 


\section{Table 4}

Percent inhibition for each of the tested CYP enzymes when screened with $10 \mu \mathrm{M}$ of CYP26 inhibitors. NI indicates no inhibition observed. * shows that activity in the presence of the inhibitor was significantly different $(\mathrm{p}<0.01)$ from that in control.

\begin{tabular}{|l|c|c|c|c|}
\hline Compound & CYP3A4 & CYP2D6 & CYP2C19 & CYP2B6 \\
\hline $\mathbf{2 2}$ & $\mathrm{NI}$ & $49 \pm 7^{*}$ & $\mathrm{NI}$ & $\mathrm{NI}$ \\
\hline $\mathbf{2 4}$ & $\mathrm{NI}$ & $\mathrm{NI}$ & $\mathrm{NI}$ & $\mathrm{NI}$ \\
\hline $\mathbf{3 0}$ & $75 \pm 8^{*}$ & $\mathrm{NI}$ & $\mathrm{NI}$ & $30 \pm 1^{*}$ \\
\hline
\end{tabular}

*activity in the presence of the test inhibitor (22 or $\mathbf{3 0}$ ) was significantly different from control 